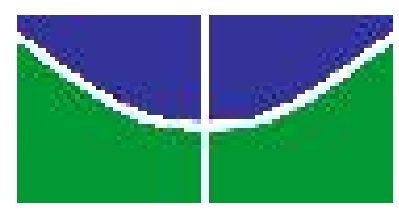

UNIVERSIDADE DE BRASÍLIA

INSTITUTO DE LETRAS

DEPARTAMENTO DE LINGUÍSTICA, PORTUGUÊS E LÍNGUAS CLÁSSICAS PROGRAMA DE PÓS-GRADUAÇÃO EM LINGUÍSTICA

PROPRIEDADES SINTÁTICAS E SEMÂNTICAS DOS ADVÉRBIOS NO PORTUGUÊS BRASILEIRO

ZENAIDE DIAS TEIXEIRA

BRASÍLIA - DF 
UNIVERSIDADE DE BRASÍLIA

INSTITUTO DE LETRAS

DEPARTAMENTO DE LINGUIISTICA, PORTUGUÊS E LÍNGUAS CLÁSSICAS

PROGRAMA DE PÓS-GRADUAÇÃO EM LINGUÍSTICA

ZENAIDE DIAS TEIXEIRA

PROPRIEDADES SINTÁTICAS E SEMÂNTICAS DOS ADVÉRBIOS NO PORTUGUÊS BRASILEIRO

Tese apresentada ao Programa de Pós-Graduação em Linguística do Departamento de Linguística, Português e Línguas Clássicas da Universidade de Brasília, como requisito parcial à obtenção do título de Doutor em Linguística.

Área de Concentração: Teoria e Análise Linguística Orientadora: Profa. Dra. Heloísa Maria Moreira Lima Salles 
Ficha catalográfica elaborada automaticamente, com os dados fornecidos pelo(a) autor(a)

Teixeira, Zenaide Dias

TP PROPRIEDADES SINTÁTICAS E SEMÂNTICAS DOS ADVÉRBIOS NO PORTUGUÊS BRASILEIRO / Zenaide Dias Teixeira; orientador Heloísa Maria Moreira Lima de Almeida Salles. -- Brasília, 2015.

$173 \mathrm{p}$

Tese (Doutorado - Doutorado em Linguística) -Universidade de Brasília, 2015.

1. Análise Linguística. 2. Língua Portuguesa Semântica. 3. Língua Portuguesa - Sintaxe. 4. Língua Portuguesa - Categorias. 5. Gramática Gerativa. I. Salles, Heloísa Maria Moreira Lima de Almeida, orient. II. Título. 


\section{PROPRIEDADES SINTÁTICAS E SEMÂNTICAS DOS ADVÉRBIOS NO PORTUGUÊS BRASILEIRO}

Tese apresentada ao Programa de Pós-Graduação em Linguística do Departamento de Linguística, Português e Línguas Clássicas da Universidade de Brasília, como requisito parcial à obtenção do título de Doutor em Linguística.

\section{Comissão Examinadora:}

Profa. Dra. Heloísa Maria Moreira Lima Salles - UnB (Orientadora)

Profa. Dra Maria Aparecida Torres Morais - USP

Profa. Dra. Maria José Foltran - UFPR

Profa. Dra. Eloísa Nascimento Silva Pilati - UnB

Profa. Dra. Helena da Silva Guerra Vicente - UnB

Profa. Dra. Rozana Reigota Naves - UnB (Suplente) 
Às pessoas que mais amo e são alegria na minha vida: minha avó, Zenaide; minha mãe, Veroneste; minha sobrinha, Júlia; minhas irmãs, Daiane e Juliana; e ao meu esposo, companheiro de todas as horas, Marcelo. 


\section{AGRADECIMENTOS}

Agradeço, em primeiro lugar, a Deus que está sempre ao meu lado, guiando os meus caminhos. Obrigada, Senhor, por iluminar-me, dar-me sabedoria e por carregar-me no colo quando eu não aguentava caminhar. Muito obrigada!

À minha família pelo apoio durante essa jornada e pela compreensão por minhas inúmeras ausências. Em especial, agradeço à minha avó, de quem também herdei o nome, Zenaide, e à minha mãe, Veroneste, que dedicaram (e dedicam) boa parte de suas vidas a mim, demonstrando carinho, cuidado e amor inenarráveis. Que me ensinaram, através de ações diárias, que é preciso ser forte e lutar por aquilo que sonhamos. À minha sobrinha, Júlia, que alegra os meus dias e que amo imensuravelmente. Às minhas irmãs, Daiane e Juliana, pelo carinho e companheirismo. Ao meu companheiro, Marcelo, por estar ao meu lado do início ao fim desta jornada, dando-me apoio incondicional. Amo muito vocês!

À minha professora orientadora, Heloísa Salles, pesquisadora competente e comprometida com a ciência, por acreditar em mim, por acompanhar-me com dedicação nesta jornada acadêmica e por demonstrar-se uma pessoa generosa sempre que precisei. Suas orientações precisas foram fundamentais na elaboração deste trabalho. Levarei sempre comigo os sentimentos de gratidão e admiração pela senhora, professora!

Aos amigos que me socorreram nas horas de angústia, e que também compartilharam momentos de alegria: Humberto Borges, pelas horas de estudos juntos, pelos cafés e, principalmente, pelos ouvidos incansáveis; José João, por acompanhar-me nessa trajetória, obrigada pelas horas ao telefone; Leonardo Ventura e Cláudia, Francisco Martins e Paula Vilela, pelo carinho, companheirismo e conversas prazerosas; Marcus Lunguinho e Djiby Mané pela disponibilidade e boa vontade em auxiliar-me.

Aos queridos colegas de pós-graduação, Ana Terra, Beatriz Carneiro, Cristiany Fernandes, Déborah Mendonça, Wanderson Bomfim, Maria Lílian, Ribamar, Ramon, Márcia Costa, Jane Castro e Moacir Júnior pelas aulas, congressos e momentos compartilhados.

Ao professor Dioney Moreira Gomes, com o qual tive a oportunidade de aprender muito durante esta jornada.

Às professoras que se dispuseram a compor a Comissão Examinadora desta tese, Maria Aparecida Torres Morais, Maria José Foltran, Eloísa Nascimento Silva Pilati, Helena da Silva Guerra Vicente e Rozana Reigota Naves, compartilhando seus 
conhecimentos e contribuindo para o aprimoramento deste trabalho e para a minha jornada como pesquisadora.

Aos colegas de trabalho da Universidade Estadual de Goiás, principalmente, Maria Eneida da Silva, Víctor Passuello e Washington Souza Melo, que me conheceram muito recentemente, mas, ainda assim, não hesitaram em propiciar-me as condições necessárias para que eu pudesse concluir esta tese.

À SEEDF (Secretaria de Estado de Educação do Distrito Federal) pela concessão de licença para estudos, que foi fundamental para o desenvolvimento desta tese.

Enfim, a todos com os quais convivi durante esse período que, de alguma maneira, contribuíram para o desenvolvimento e conclusão deste trabalho. Meus sinceros agradecimentos! 


\section{RESUMO}

Esta tese examina as propriedades sintáticas e semânticas dos advérbios no português brasileiro (PB), considerando, em particular, os advérbios locativos. O interesse por esse tema é decorrente da heterogeneidade do comportamento dos advérbios no PB (e translinguisticamente), o que levanta alguns problemas em relação a sua categorização. Adotando a Teoria Gerativa, na versão do Programa Minimalista (Chomsky, 1995), a nossa hipótese de trabalho é de que advérbios constituem uma categoria autônoma, na qual há subclasses. Para abordar a questão, inicialmente, buscamos o legado helenístico na descrição das categorias, em particular, na descrição dos advérbios. Depois, investigamos as propriedades dos advérbios em oposição às preposições (Lemle, 1984; Bomfim, 1988; e Lobato, 1989), aos pronomes (Bomfim, 1988) e aos adjetivos (Lobato, 2005/2008; Leung, 2007; e Foltran, 2010), que confirmam seu caráter autônomo. Em relação à distribuição sintática dos advérbios, consideramos a contribuição seminal de Jackendoff (1972) dentro da teoria gerativa, além de considerar o debate quanto a se sua distribuição é sintática ou semanticamente determinada (Cinque, 1999; Ernst, 2002; Costa, 2008; Pereira, 2011), o que nos leva à conclusão de que propriedades relevantes para a presente discussão são capturadas pela distinção entre advérbios altos e baixos, e pela possibilidade de predicar ou não de certas propriedades do evento/nominal, com implicações para a codificação do escopo semântico. Considerando que os advérbios dividem-se em duas grandes classes, os advérbios sentenciais e os advérbios de VP, observamos que dentro do grupo de advérbios de VP, temos uma subclasse com comportamento distinto, pois podem ser realizados não apenas por PPs/advérbios (locativos), mas também por bare NPs (cf. Larson, 1985). Interessantemente, no PB, advérbios circunstanciais podem ser encontrados na posição de sujeito, conforme originalmente notado em Pontes (1986, 1987), sob o rótulo de construções de tópico-sujeito (cf. Aqui/ Essa casa bate sol), e posteriormente discutidas em Galves (1998), entre outros. Em seguida, apresentamos o estudo de Bresnan (1994) para a inversão locativa no chicheŵa e no inglês, em que a correlação com a concordância é estabelecida. Assumimos então a proposta de Pilati $(2002,2006)$ de que as construções VS no PB são exemplos de inversão locativa, nas quais estão incluídas construções de tópico sujeito (cf. Avelar e Cyrino 2008a, b; Avelar 2009). Assumimos Munhoz e Naves (2010) e Munhoz (2011) e discutimos a ocorrência de PP/ Advérbios e DP locativos nas estruturas de tópico-sujeito, em relação ao desencadeamento de concordância verbal e ao seu estatuto com verbos inacusativos biargumentais. Observamos que advérbios locativos também compartilham da distribuição sintática dos PPs e NPs locativos. Adotando a proposta de Cinque (1999), que distingue 
advérbios altos e advérbios baixos, e dando continuidade à proposta de Teixeira e Salles (2013a, b), notamos que a realização da posição de sujeito interage com a tipologia sintática dos advérbios, pois é restrita aos advérbios circunstanciais ditos de VP, em particular, os locativos, embora, diferentemente do DP locativo, não controlem a concordância de número: 'Esse sítio e essa fazenda dão muita banana'; '*Aqui e ali dão muita banana'. Nossa hipótese é a de que, diferentemente dos NPs plenos, os advérbios não manifestam a categoria de número, inerentemente, mas manifestam a categoria de pessoa. Assumindo a hipótese de Baker (2004), que postula que nomes são marcados pelo traço $[+\mathrm{N}]$ por possuírem índice referencial, propomos (seguindo Pilati, Naves, Salles 2013), que advérbios locativos possuem índice referencial, que é formalmente codificado pelos traços [+dêitico] e [+( $\left.3^{\mathrm{a}}\right)$ pessoa] (referencial). Nossa conclusão é a de que advérbios locativos na posição de sujeito são gerados como advérbio de VP/ ou argumento locativo, carregando os seguintes traços formais: [+dêitico] e [+ $\left(3^{a}\right)$ pessoa].

Palavras-chave: Advérbios. Locativos. Posição de sujeito. Concordância. 


\begin{abstract}
This thesis examines the syntactic and the semantic properties of adverbs in Brazilian Portuguese (BP), considering, in particular, locative adverbs. The interest on this topic lies on the heterogeneous behaviour of adverbs in PB (and crosslinguistically), which raises a number of problems for its categorization. Assuming the framework of the generative theory, as well as the Minimalist Program Minimalista (Chomsky, 1995), our working hypothesis is that adverbs constitute an autonomous category, which includes subtypes. In order to investigate this matter, we, initially, start from the helenistic approach in the description of lexical categories, searching for the description of adverbs. Next, we investigate the properties of the adverb as opposed to prepositions (Lemle, 1984; Bomfim, 1988; e Lobato, 1989), pronouns (Bomfim, 1988) and adjetives (Lobato, 2005/2008; Leung, 2007; e Foltran, 2010), which confirm its autonomous character. Regarding the syntactic distribution of adverbs, we take into consideration Jackendoff's (1972) seminal contribution within the generative framework, further considering the debate on whether it is synatically or semantically determined (cf. Cinque, 1999, Ernst 2002; Costa, 2008; Pereira 2011), which leads to the conclusion that the relevant properties for the present discussion are captured by the distinction between high and low adverbs, and on whether they are predicational or not, with implications for the expression of scope. Considering that adverbial types distinguish two classes, namely sentential adverbs and VP adverbs, we note that a subtype of VP adverbs display a distinct behavior, as they can be realized not only by PPs/(locative) adverbs, but also by bare NPs (cf. Larson 1988). Interestingly in BP, circumstantial adverbs may be found in subject position, as originally noted in Pontes (1986, 1987), under the label of topic-subject constructions (cf. Aquil Essa casa bate sol), and further discussed in Galves (1998), among others. We then present Bresnan's (1994) study of locative inversion in Chichewa and English, in which a correlation with agreement is established. We then assume Pilati's $(2002,2006)$ proposal that VS constructions in BP are an instance of locative inversion, which include topic-subject constructions (cf. also Avelar e Cyrino 2008a, b; Avelar 2009). Assuming Munhoz e Naves (2010) and Munhoz (2011), we furhter show that regarding agreement, the occurrence of PP/ Adverbs and locative DP in topic-subject constructions is found biargumental unaccusatives. We note that locative adverbs share the distribution of locative PPs and NPs. Assuming Cinque's (1999) proposal of ditinguishing high and low adverbs and following Teixeira \& Salles' $(2013 \mathrm{a}, \mathrm{b})$ analyses, we note that the realization of adverbs in subject position interacts with the syntactic typology of adverbs, as it is restricted to circumstantial VP adverbs, although, contrary to the locative DP, they do not trigger number agreement: "Esse sítio e
\end{abstract}


essa fazenda dão muita banana"; "*Aqui e ali dão muita banana”. Our proposal is that, contrary to full DPs, adverbs do not bear the number feature, inherently, only bearing the person feature, which is referential. Assuming Baker's (2004) proposal in which nouns are taken to bear a referential index, we propose (following Pilati, Naves e Salles (2013)) that locative adverbs also bear a referential index, which is formally encoded by the feature [+deictic] and (referential) $\left(3^{\text {rd }}\right)$ [person]. Our conclusion is that locative adverbs in subject position are generated as a VP adverb/ or a locative argument, bearing the following formal features: [+deictic] and [+ $\left(3^{\text {rd }}\right)$ person].

Keywords: Adverbs. Locatives. Subject position. Agreement. 


\section{SUMÁRIO}

Introdução. .14

Capítulo 1 - Das categorias: o advérbio em questão.

1.1 Os advérbios e a tradição gramatical...... .19

1.2 A teoria gerativa. .24

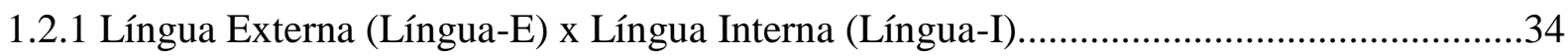

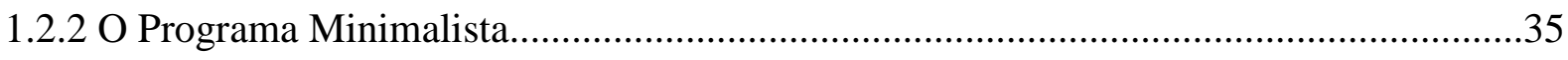

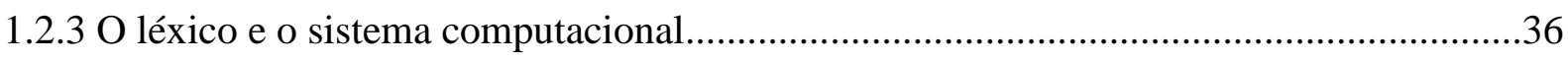

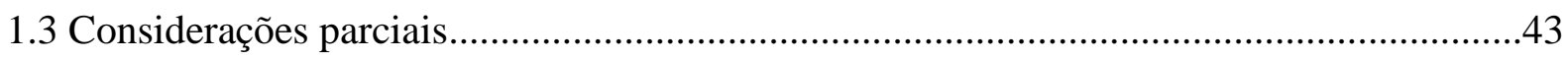

Capítulo 2 - Advérbios: o estatuto categorial. .45

2.1 Advérbios e preposições: um diálogo entre Lemle (1984), Bomfim (1988) e Lobato (1989) . .46

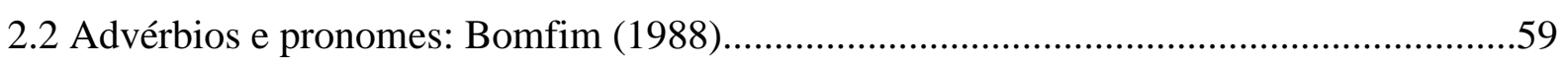

2.3 Advérbios e adjetivos: Lobato (2005/2008), Leung (2007), Foltran (2010).....................63

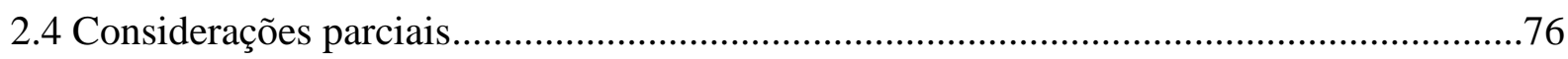

Capítulo 3 - A distribuição dos advérbios na estrutura oracional. .80

3.1 Advérbios: estrutura e informação veiculada -Jackendoff (1972)...................................80

3.1.1 A análise de Jackendoff (1972) e suas aplicações ao português.....................................83

3.2 Advérbios de VP e advérbios sentenciais: a contribuição de Cinque (1999) em questão..87

3.2.1 Advérbios de VP: sobre os circunstanciais.

3.2.2 A relação entre o mapeamento sintático e a interpretação semântica do advérbio em português: Costa (2008)............................................................................................ 95

3.3 Advérbios como especificadores de núcleos funcionais (Cinque, 1999) e uma proposta de análise para o advérbio "lá" no português brasileiro (Pereira, 2011)....................................100

3.3.1 "Lá" em questões retóricas e em sentenças imperativas (em Spec, FocusP).................101

3.3.2 "Lá" em construções inacusativas e em construções existenciais (em Spec, TopP).....105

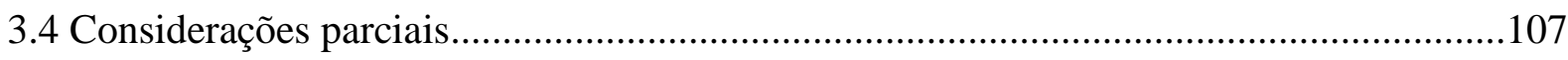


4.1 A Inversão Locativa e a posição de sujeito: Bresnan (1994)...........................................112

4.1.1 Inversão Locativa no PB: a análise de Pilati (2006)..................................................119

4.1.2 O PP locativo na posição sujeito no PB: Avelar e Cyrino (2008a, b), (2009); Avelar (2009).

4.2 NPs locativos na posição de sujeito.

4.2.1 Bare-NP Adverbs: Larson (1985).

4.2.2 NPs locativos na posição de sujeito: Pontes (1986) e (1987).

4.2.3 Tópico sujeito e tópico não sujeito no PB: Galves (1998)........................................... 142

4.2.4 O licenciamento do NP locativo na posição de sujeito.

4.3 Advérbios locativos na posição de sujeito: a geometria de traços (formais) dos advérbios

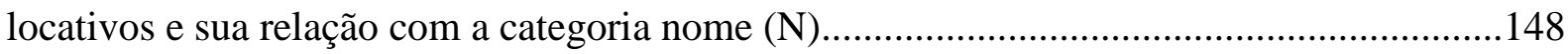

4.4 Considerações parciais. 158

Considerações Finais.

Referências bibliográficas. 


\section{INTRODUÇÃO}

Sabemos que o estudo das categorias lexicais tem longa tradição. No entanto, as questões relativas à categorização são objeto de discussão permanente, ao se constatar a existência de itens do léxico que manifestam propriedades ambíguas do ponto de vista de uma distinção baseada em critérios formais de oposição entre as classes. Nesta tese, detemo-nos na investigação das propriedades sintáticas e semânticas da categoria 'advérbio', tendo em vista algumas questões que se depreendem em sua caracterização.

Na discussão, será adotada a perspectiva da gramática gerativa (cf. CHOMSKY 1981, 1986, 1995), sendo os estudos tradicionais apresentados de acordo com a necessidade de situar um dado conceito ou uma dada propriedade relevante. A literatura (cf. LEMLE 1984; BOMFIM 1988; LOBATO 1989; 2005/ 2008) demonstra que muitas palavras rotuladas advérbio possuem comportamento complexo no $\mathrm{PB}$ e parecem compartilhar a distribuição sintática de outras categorias, mantendo ainda semelhança semântica. Estes fatos colocam em questão o seu estatuto categorial, como podemos observar em (1), (2) e (3):

(1) a. Ela assiste ao filme atentamente.

b. Ela assiste ao filme com atenção.

(2) a. Hoje é um bom dia para descanso.

b. Ela é a melhor pessoa que conheço.

(3) a. A cerveja que desce redondo.

c. A cerveja que desce redondamente.

Os dados acima demonstram que palavras consideradas advérbios compartilham da distribuição sintática de sintagmas preposicionais (1), de elementos pronominais (2) e de elementos adjetivais (3), o que traz questionamentos sobre como cada categoria se distribui, e que traços formais são relevantes para garantir que sejam intercambiáveis. Postulamos que, por compartilharem distribuição sintática, tais elementos podem compartilhar propriedades formais. Assim, levantamos a primeira questão desta tese:

Questão 1: Quais propriedades os advérbios compartilham com outras classes? Quais propriedades os distinguem? Possuindo propriedades distintas e compartilhadas, é possível 
supor que pertencem à mesma categoria 'advérbio'? Pertencendo à mesma categoria, é possível postular subclasses? Pertencendo a categorias distintas, que categorias são essas?

Observamos, ainda, que advérbios possuem alta mobilidade na estrutura oracional, podendo ocupar várias posições. Outros advérbios possuem restrições em sua mobilidade (cf. Jackenfoff, 1972; Gonzaga, 1997; Cinque, 1999; Perini, 2006; Costa, 2008), como demonstram os dados abaixo:

(4) a. Frequentemente ela viaja para Natal.

b. Ela frequentemente viaja para Natal.

c. Ela viaja frequentemente para Natal.

d. Ela viaja para Natal frequentemente.

(5) a. * Completamente eu abandonei o projeto.

b. *Eu completamente abandonei o projeto.

c. Eu abandonei completamente o projeto.

d. Eu abandonei o projeto completamente.

Alguns advérbios, além de restrição em determinadas posições, são utilizados como categoria codificadora de propriedades evidenciais, em que se depreende o ponto de vista do falante, como demonstram os dados abaixo, sendo realizados, por hipótese, como categorias da periferia da oração (cf. Pereira, 2011):

(6) a. Sei lá!

b. Quero lá ver isso!

c. Lá vem você com essa ideia!

Observando dados como os de (4) a (6), levantamos a segunda questão desta tese:

Questão 2: Tendo em vista a maior ou menor mobilidade dos advérbios na estrutura oracional, que propriedades licenciam sua distribuição sintática? Existe correlação entre a mobilidade dos elementos adverbiais e sua distribuição em subclasses? De que maneira as propriedades de cada subclasse interage com a distribuição sintática desses elementos? 
Por último, e retomando o fenômeno em (2), em que o advérbio aparece como sujeito da oração, observamos que, no PB, a distribuição dos advérbios na posição de sujeito não se restringe a predicados equativos (com ou sem cópula), como observado em várias línguas. Também parece ser possível encontrar advérbios locativos na posição de sujeito de orações com verbos intransitivos em que o argumento (interno) do verbo é realizado em posição préverbal - uma questão que tem sido amplamente debatida na literatura, especialmente a partir do trabalho seminal de Pontes (1986, 1987):

(7) a. *(Aqui) bate sol.
b. *(Ali) cabe as roupas.

E então nos perguntamos:

Questão 3: Os advérbios, nesses casos, ocupam a posição de sujeito no PB ou estão na periferia da oração, por deslocamento à esquerda? Em cada caso, quais são os fatores sintáticos e semânticos responsáveis pelo licenciamento de advérbios? Que fatores restringem a presença de outros advérbios nessa posição?

Percebe-se, então, que a categoria advérbio é de difícil caracterização, pois as palavras que tradicionalmente compõem esta classe manifestam comportamentos sintático e semântico distintos, o que sugere a existência de subclasses no âmbito da classe dos advérbios.

Nesse sentido, este trabalho discute, na perspectiva da teoria gerativa, as propriedades formais dos advérbios, considerando, particularmente, as implicações entre a posição sintática e a categorização. Apesar de examinarmos, primordialmente, os dados do PB, consideraremos trabalhos anteriores que analisaram dados de outras línguas, e que podem contribuir para a discussão.

Para abordar as questões aqui levantadas, a tese está organizada em quatro capítulos. No capítulo 1, fazemos uma breve exposição de aspectos históricos da tradição gramatical, remontando à contribuição dos filósofos gregos na descrição das categorias gramaticais, observando, em particular, o legado helenístico na descrição dos advérbios. Em seguida, apresentamos a forma como as ideias de categorização são formuladas no âmbito da Teoria Gerativa, referencial teórico que embasa esta pesquisa, fazendo uma síntese da proposta em relação ao modelo da Gramática Universal, conforme formulado no chamado Programa Minimalista de investigação linguística. 
Para refletir sobre a nossa primeira questão, no capítulo 2, discutiremos as relações entre advérbios e outras categorias. Primeiro, retomaremos os estudos de Lemle (1984), Bomfim (1988) e Lobato (1989), que discutem a possibilidade de advérbios pertencerem à classe das preposições. Retornaremos aos estudos de Bomfim (1988) para discutir, em particular, as relações entre advérbios e pronomes. Em seguida, traremos estudo de Lobato (2008), que analisa a hipótese de flutuação entre advérbios (de modo) e adjetivos, propondo que não se trata de flutuação, mas de duas classes distintas, já que cada forma ocorre como modificadora ou do predicado, ou de uma categoria nominal na estrutura léxico-conceptual do predicado. Os dados examinados por Lobato são retomados por Leung (2007) e por Foltran (2010), em que os elementos são definidos por uma abordagem baseada na classe gramatical.

Para refletir sobre a nossa segunda questão, no capítulo 3, discutiremos a distribuição dos advérbios na estrutura oracional, na perspectiva da gramática gerativa. Para essa reflexão, recorremos ao estudo seminal de Jackendoff (1972), que analisa a distribuição dos advérbios na estrutura oracional do inglês, e examinamos suas aplicações para o PB, baseando-nos no estudo de Gonzaga (1997). Seguimos com a tipologia de advérbios proposta por Cinque (1999), com base em dados do francês e do italiano, que adota uma abordagem para a distribuição desses elementos na estrutura oracional, em que a cada tipo de advérbio corresponde uma posição sintática distinta. Será demonstrado também que a hipótese de Cinque (1999) distingue-se das abordagens em que a distribuição dos advérbios é determinada por relações de escopo, tendo em vista as propriedades léxico-semânticas desses elementos (conforme Ernst 1984; 2002). Em seguida, traremos a análise de Costa (2008), que avalia a proposta de Cinque (1999), considerando dados do português europeu, chegando à conclusão, com base em estudo prévio de Ernst (1984), de que as propriedades lexicais dos advérbios têm implicações para sua distribuição, o que demonstra a necessidade de uma análise detalhada da semântica lexical dos advérbios para se definir sua distribuição em termos de escopo. Finalizamos o capítulo com a análise de Pereira (2011), que investiga as propriedades formais do advérbio 'lá' no PB, em usos discursivamente marcados, em que a abordagem de Cinque (1999) é adotada, resultando em uma proposta que situa tais elementos na posição de especificador de núcleos funcionais na periferia da oração (no domínio de CP). Dessa discussão, extraímos a conclusão de que existem subclasses de advérbios, sendo relevante para a presente discussão a distinção entre advérbios altos e baixos, esses últimos definidos como advérbios internos ao sintagma verbal (VP). Nesse contexto, estão os advérbios circunstanciais de lugar, que nos interessam em particular. 
Para refletir sobre a terceira questão, discutiremos, no capítulo 4, a hipótese de os advérbios ocuparem posição argumental, mais especificamente, a posição de sujeito. Neste capítulo, nos deteremos no exame de advérbios de VP, em particular, os locativos. Investigaremos as possíveis propriedades formais que possibilitam a esses advérbios ocupar essa posição. Para desenvolver o capítulo, iniciamos com uma breve exposição sobre o preenchimento da posição de sujeito por argumentos locativos realizados como sintagmas nominais e como sintagmas preposicionais e adverbiais, e seguimos com o estudo de Larson (1985), que analisa os chamados Bare-NP Adverbs (sintagmas nominais que realizam argumentos locativos e temporais, sem o acompanhamento de preposição). Este estudo é importante na medida em que demonstra que advérbios locativos (na codificação de tempo e espaço) podem ser realizados como NPs ou como PPs, o que nos leva à hipótese de que podem compartilhar propriedades, que contribuirão para refletirmos sobre o estatuto categorial do advérbio e sobre a hipótese de existência de subclasses, além das condições que determinam sua ocorrência na posição de sujeito. Seguimos com a discussão sobre NPs e PPs locativos ocorrerem na posição de sujeito no PB, partindo dos estudos de Pontes (1986) e (1987). Para discutir essa questão, apresentamos inicialmente a análise de Bresnan (1994) sobre a inversão locativa em inglês, a qual é assumida em Pilati (2006) na análise de estruturas VS no PB, que incluem as estruturas de tópico-sujeito, em que locativos ocorrem na primeira posição. Passamos então a discutir as análises de Galves (1998), Avelar e Cyrino (2008) e (2009), Avelar (2009) para as estruturas de tópico-sujeito no PB. Para finalizar a discussão, retomaremos alguns pontos dos estudos citados, bem como nossas reflexões anteriores, em particular, Teixeira e Salles (2013a; b), e propomos que as construções de tópico-sujeito, em que PPs/NPs/Advérbios locativos ocorrem na posição de sujeito como argumentos do predicado no PB permitem demonstrar que a categoria advérbio inserida nesse contexto é marcada com índice de referencialidade, o qual corresponde ao traço [+dêitico] e com o traço de ( $3^{\mathrm{a}}$ ) Pessoa, estando ausente o traço de número, o que se confirma pelo fato de não controlar concordância de número. Esse conjunto de traços permite distinguir tais elementos do expletivo (nulo ou foneticamente realizado). Por fim, apresentamos nossas conclusões, bem como as possibilidades de pesquisas futuras. 


\section{CAPÍTULO 1 \\ DAS CATEGORIAS: O ADVÉRBIO EM QUESTÃO}

Iniciaremos o nosso trabalho com uma breve retomada sobre a história dos estudos das categorias desde os gregos. Buscamos neste capítulo perceber o legado categorial helenístico para a tradição gramatical, em particular, o legado relacionado à categoria advérbio. Observaremos algumas questões relativas à caracterização tradicional desta classe de palavras e, em seguida, faremos uma breve exposição sobre a Teoria que embasará a nossa análise: a Teoria Gerativa.

\subsection{Os advérbios e a tradição gramatical}

O interesse pela linguagem é verificado na história do pensamento grego, remontando ao século $\mathrm{V}$ a. C. Os filósofos gregos muito contribuíram para as reflexões sobre a linguagem e para o que hoje é a gramática tradicional ocidental. Platão (428 - 347 a.C., aproximadamente), dentro do que se encontra registrado, foi o primeiro a separar as partes do discurso: no Crátilo, o filósofo discute a hipótese de que a linguagem diz as coisas, e o lógos é apresentado como composto de elementos, da mesma maneira que aquilo que é retratado pelo lógos é também composto de elementos. O que é retratado no lógos possui elementos que correspondem aos onómata e outros que correspondem aos rhémata, que juntos, dão a imagem plena. Segundo Neves (2005), Platão desenvolveu a distinção ónoma/rhêma no Sofista, em que Teeteto, personagem do diálogo, afirma que as coisas são divididas em ação (práxis) e agente (prátton), sendo a ação identificada como rhêma e o agente como ónoma. Dessa maneira, a proposição é um complexo de elementos heterogêneos, constituindo-se com nome e verbo.

Aristóteles (384 - 322 a.C., aproximadamente) mantém a bipartição nome/verbo, como Platão, mas acrescenta que "justamente como elementos que compõem o lógos, eles se opõem a ele, já que são elementos significativos, enquanto os elementos em que eles próprios se decompõem não são significativos" (in Neves, 2005:144). É Aristóteles que traz um exame mais explícito da articulação dos termos do discurso, que elabora um sistema de conceitos pela linguagem. Numa concepção aristotélica, examinar a proposição é examinar "o modo de dizer os seres segundo uma ligação e nela se põem seres gramaticais" (in Neves, 2005: 74); e as coisas que são ditas sem entrar em uma combinação são categorias: "a substância; ou quanto; ou qual; ou em relação a quê; ou onde; ou quando; ou estar em posição; ou estar em estado; ou fazer; ou sofrer" (Aristóteles, Categorias, 4, 1 b 25 in Neves, 2005: 75). Segundo 
Neves, o pensamento da estrutura da língua como correspondente à estrutura do mundo é o ponto fundamental da teoria aristotélica. Assim, as categorias são as informações mais gerais daquilo que se diz do ser ou sobre os modos distintos em que o ser é declarado. O surgimento das partes do discurso (categorias gramaticais) baseia-se, então, em sucessivas dicotomizações e é marcado pelo método de definição e de classificação aristotélico.

Reconhecendo a relevância da contribuição dos filósofos, Neves (2005) aponta que é com os gramáticos que se encontra um plano geral de classificação dos fatos linguísticos, o qual carrega uma herança filosófica que marca suas considerações. Na Antiguidade, Dionísio o Trácio (nascido em Alexandria, viveu entre 170 e 90 a.C.) foi o verdadeiro organizador da arte da gramática, dando-lhe uma forma cujos traços podem ser reconhecidos ainda hoje na gramática ocidental. Na obra de Dionísio, a primeira gramática do ocidente, abrigava-se apenas a fonética e a morfologia, não se abordava a sintaxe. E, na parte da morfologia - que representa a tradição da escola de Aristarco -, constavam 8 (oito) categorias gramaticais: nome, verbo, conjunção, particípio, artigo, pronome, preposição e advérbio. Segundo Neves (2005), embora o manual de Dionísio não demonstre uma organização global, apresenta um procedimento para classificar as palavras, demonstrando que, nas definições, prevalecem os critérios formais, interferindo flexões e posição, como podemos observar no quadro abaixo, proposto por Neves (2005: 253): 


\begin{tabular}{|c|c|c|c|c|c|c|c|c|c|c|}
\hline \multicolumn{10}{|c|}{ Indicações gramaticais } & \multirow{3}{*}{$\begin{array}{c}\text { Indicações } \\
\text { extragramaticais }\end{array}$} \\
\hline \multicolumn{7}{|c|}{ De flexão } & $\begin{array}{c}\mathrm{De} \\
\text { distribuicão }\end{array}$ & $\begin{array}{c}\text { De } \\
\text { morfologia }\end{array}$ & De sintaxe & \\
\hline & & Caso & Tempo & Pessoa & Número & Voz & & & & \\
\hline Nome & $\begin{array}{l}\text { Parte do } \\
\text { discurso }\end{array}$ & $\begin{array}{l}\text { Com } \\
\text { casos }\end{array}$ & & & & & & & & $\begin{array}{c}\text { Que, de modo } \\
\text { comum ou próprio, } \\
\text { indica objeto ou ação }\end{array}$ \\
\hline Verbo & Palavra & $\begin{array}{l}\text { Sem } \\
\text { casos }\end{array}$ & $\begin{array}{l}\text { Que } \\
\text { indica } \\
\text { tempo }\end{array}$ & $\begin{array}{c}\text { Que indica } \\
\text { pessoas }\end{array}$ & $\begin{array}{c}\text { (que } \\
\text { indica) } \\
\text { números }\end{array}$ & $\begin{array}{c}\text { Representando ação } \\
\text { praticada ou } \\
\text { recebida }\end{array}$ & & & & \\
\hline Particípio & Palavra & \multicolumn{5}{|c|}{ Que participa da propriedade dos verbos e dos nomes } & & & & \\
\hline Artigo & $\begin{array}{l}\text { Parte do } \\
\text { discurso }\end{array}$ & $\begin{array}{l}\text { Com } \\
\text { casos }\end{array}$ & & & & & $\begin{array}{l}\text { Que se coloca } \\
\text { antes ou } \\
\text { depois dos } \\
\text { nomes }\end{array}$ & & & \\
\hline Pronome & Palavra & & & & & & $\begin{array}{c}\text { Usada no } \\
\text { lugar do nome }\end{array}$ & & & \\
\hline Preposição & Palavra & & & & & & $\begin{array}{c}\text { Que se coloca } \\
\text { antes de todas } \\
\text { as partes do } \\
\text { discurso }\end{array}$ & $\begin{array}{c}\text { Em } \\
\text { composição }\end{array}$ & $\begin{array}{c}\text { Em } \\
\text { construção }\end{array}$ & \\
\hline Advérbio & $\begin{array}{l}\text { Parte do } \\
\text { discurso }\end{array}$ & $\begin{array}{l}\text { Sem } \\
\text { flexões }\end{array}$ & $\begin{array}{l}\text { Sem } \\
\text { flexões }\end{array}$ & $\begin{array}{c}\text { Sem } \\
\text { flexões }\end{array}$ & $\begin{array}{c}\text { Sem } \\
\text { flexões }\end{array}$ & Sem flexões & $\begin{array}{c}\text { Colocada } \\
\text { antes ou } \\
\text { depois do } \\
\text { verbo }\end{array}$ & & & \\
\hline Conjunção & Palavra & & & & & & & & & $\begin{array}{c}\text { Que liga com } \\
\text { ordenação o } \\
\text { pensamento e revela } \\
\text { os vazios da } \\
\text { expressão }\end{array}$ \\
\hline
\end{tabular}

Observa-se que a definição de advérbio é totalmente formal, pautando-se pela ausência de qualquer flexão e por sua distribuição. Segundo Neves, o manual de Dionísio incluía interjeições na relação de advérbios, que se abrigavam sob os rótulos de advérbio de dor (ex.: ioú, interjeição de dor), de admiração (ex.: babaî, interjeição de admiração), de exortação (ex.: ê̂a, interjeição de exortação), de inspiração divina (ex.: euoí, evoé).

Apolônio Díscolo (também nascido em Alexandria, viveu na primeira metade do século II d.C) foi, assim como seu filho Herodiano, o gramático de maior projeção na época dos imperadores romanos, representando, segundo Neves, o ponto culminante da sabedoria gramatical na Antiguidade. Além de trazer as categorias gramaticais que constavam em Dionísio o Trácio, ele trata, pela primeira vez, especificamente da sintaxe. Segundo Egger (1854, p.52-4 in Neves, 2005: 130), uma das regras do método de Apolônio para classificar ou definir uma palavra é considerar a forma, ou o som, e o sentido; é o sentido que determina a classe a qual a palavra pertence, tendo prevalência sobre a forma; no entanto, a forma é considerada por Apolônio como um índice útil, no qual a terminação é o mais relevante. Obedecendo a esse critério, de colocar o conteúdo nocional em primeiro lugar, Apolônio define o advérbio como "uma palavra indeclinável que se predica de maneira geral ou 
particular aos modos dos verbos e que, sem eles, não pode completar o pensamento", (Neves, 2005:191) não possuindo sentido completo sem um verbo ou particípio, assim como o adjetivo não teria sentido completo sem um nome; enquanto o verbo e o nome veiculam sentido completo sem advérbio e sem adjetivo. Apolônio apontava também o fato de que alguns advérbios podem juntar-se a qualquer verbo enquanto outros só podem juntar-se a algumas formas, pois ou se juntam aos verbos em geral, ou são utilizados em construções especiais.

Observando as classificações propostas pelos gregos, podemos perceber a herança helenística na gramática tradicional no que diz respeito às categorias: das dez classes gramaticais que temos hoje, sete já constavam na gramática de Dionísio o Trácio: nome, verbo, conjunção, artigo, pronome, preposição e advérbio. Na definição de advérbio na gramática tradicional, também encontramos heranças dos gramáticos gregos: são palavras invariáveis, que modificam fundamentalmente o verbo e, a essa função básica geral, certos advérbios acrescentam outras como modificar um adjetivo, outro advérbio ou uma oração (cf. CUNHA; CINTRA 2001).

Contudo, a descrição desse conjunto de palavras não é trivial. Bastam poucos exemplos para demonstrar também a capacidade dos chamados advérbios de modificar classes gramaticais diversas, como podemos observar nos dados abaixo (cf. Macambira, 2001: 4245), em que temos advérbios que modificam pronome (1) e (2), numeral (3), preposição (4), conjunção (5) e substantivo (6), exemplos do autor (p.42-45):

(1) O guia da excursão já nos esclareceu quase tudo.

(2) Isso aqui é fácil.

(3) O caderno tem exatamente sessenta folhas.

(4) O pássaro voava exatamente sobre a cabeça do adormecido.

(5) Fechou a porta pouco antes que o ladrão viesse.

(6) Meu amigo aqui formou-se em Roma.

Segundo Câmara Jr. (1979), os advérbios são formas nominais ou pronominais que trazem um sentido suplementar à significação do verbo, por isso os gregos chamaram-no epirrhéma (acrescentado ao verbo; gr. rhéma 'verbo'), traduzido pelos gramáticos latinos como adverbium. $\mathrm{O}$ autor aponta três tipos básicos de advérbios: os locativos e os temporais, que são de natureza pronominal, pois situam o evento no espaço ou no tempo; e os modais, de natureza nominal, independente de sua origem ou forma, pois assinalam o modo de ser do 
evento. É a eles que a tradição se refere quando define "advérbio como 'palavra que modifica um verbo, um adjetivo ou outro advérbio', pois um 'modo de ser' pode complementar tanto uma atividade como uma qualidade atribuída a um substantivo dado ou outro modo de ser" (Câmara Jr. 1979: 116).

$\mathrm{O}$ autor reconhece as dificuldades em caracterizar essas palavras, apontando que perturba a classificação dos advérbios sua "extrema mobilidade semântica e funcional" (Câmara Jr., 1979:122). Para o autor, a mobilidade semântica se manifesta na frequente mudança de sentido, como podemos verificar em (7a), em que antes indica uma sequência em contraste com depois; e (7b) em que antes equivale a preferir:

(7) a.João chegou antes; Antônio chegou depois.

b. Antes isso do que aquilo.

A mobilidade do ponto de vista funcional se manifesta pelo frequente uso de advérbios para enunciações em sequência, e alguns advérbios são até fixados como conjunções coordenativas:

(8) Foram mal na prova, quando poderiam ter ido bem.

Na relação de subordinação, Câmara Jr. (1979) aponta o processo geral em que se associa uma preposição (de) ou uma conjunção (que) a alguns advérbios para aplicá-los como preposições ou conjunções subordinativas, que continuam com a informação adverbial no centro da informação, mas adquirem mais uma função, a conectiva:

(9) Sempre que espero muito dele, fico decepcionada.

Câmara Jr. (2004: 77) afirma que, inicialmente, são três os critérios para classificar uma palavra em uma língua: a) o critério semântico, relacionado ao "ponto de vista do universo a que se incorpora uma língua"; b) o critério formal ou mórfico, baseado nas “propriedades gramaticais que o vocábulo pode apresentar"; e c) o critério funcional, relativo “à função ou ao papel da palavra na sentença”. Nesse sentido, os estudos linguísticos apontam para fenômenos como o uso pronominal de advérbios (10a), a ocorrência de advérbios em posição sintática de argumento (10b), ou ainda, para a flutuação categorial (10c): 
(10) a. Hoje é dia de descanso.

b. Aqui bate sol.

c. O carro anda rápido/ rapidamente.

Quanto ao escopo, dependendo da posição em que o advérbio é colocado, ele pode modificar, além do sintagma verbal (11), até mesmo toda a oração (12):

(11) Preciso realmente disso.

(12) Realmente, preciso disso.

Em Teixeira (2008; 2010), analisamos a subcategorização semântica dos advérbios, que, nas gramáticas tradicionais, são divididos em advérbios de modo, tempo, lugar, negação, afirmação, intensidade, companhia e dúvida. E constatamos que essa subcategorização ainda pode desdobrar-se em, pelo menos, 26 outros tipos. No entanto, essa classificação semântica dos advérbios não se mostra suficiente para explicar suas propriedades, uma vez que existem propriedades compartilhadas, e também propriedades privativas de uma subcategoria, conforme observado em Teixeira (2011).

Os dados apresentados até agora colocam, portanto, diferentes questões em relação aos advérbios, de natureza semântica e sintática. Antes de seguirmos com a discussão sobre o tratamento teórico a ser dado às questões apresentadas até o momento, referentes às propriedades sintáticas e semânticas dos advérbios, faremos, na próxima seção, uma breve exposição sobre as bases epistemológicas e o quadro teórico gerativista, que será adotado nesta tese. Como será demonstrado, a noção de categoria é essencial para a teoria gerativa.

\subsection{A Teoria Gerativa}

Até meados do século $\mathrm{XX}$, os estudos linguísticos centravam-se na langue saussureana, sendo a língua vista como um sistema de signos, do qual os falantes detinham apenas uma parte, estando a totalidade realizada na comunidade linguística - de que se extrai a noção de que a langue é social:

(...) trata-se de um tesouro depositado pela prática da fala em todos os indivíduos pertencentes à mesma comunidade, um sistema gramatical que existe virtualmente em cada cérebro ou, mais exatamente, nos cérebros dum conjunto de indivíduos, pois a língua não está completa em nenhum, e só na massa ela existe de modo completo (Saussure, 2006: 21). 
A teoria gerativa, tal como formulada originalmente por Noam Chomsky, questionou as teses estruturalistas, e fundamentos behavioristas, mudou o foco dos estudos linguísticos, deixando de considerar a língua como sistema de signos socialmente representados, para abordar o conhecimento de língua de cada falante, definido como a Faculdade da Linguagem (FL) - capacidade inata e específica da espécie, que permite ao ser humano adquirir e usar uma língua natural. Desse ponto de vista, a linguagem é um componente da mente humana, representado fisicamente no cérebro e integrante do sistema biológico da espécie.

Estudar a linguagem humana, numa perspectiva gerativa, é estudar um aspecto particular das faculdades mentais da espécie humana. A FL "não é um sistema homogêneo, mas o resultado da interação complexa entre vários sistemas ou módulos autônomos de natureza diversa, caracterizados por regras e princípios específicos a cada um deles" (Raposo, 1992: 15). Segundo Chomsky, as línguas se baseiam em princípios simples que entram em interação para formar estruturas complexas, desse modo, em interação com outros sistemas, existe um componente da mente/cérebro dedicado à linguagem - (FL). O autor assume que "a faculdade da linguagem possui pelo menos dois componentes: um sistema cognitivo que guarda informação, e sistemas de performance que têm acesso a essa informação e a usam de várias maneiras" (Chomsky, 1995: 40).

A Teoria Gerativa, segundo Lobato (1986: 107) é "uma tentativa de formalização dos fatos linguísticos, isto é, de tratamento matemático, ou, ainda em outras palavras, de tratamento preciso e explícito das propriedades das línguas naturais". Pode-se abordar questões sobre a língua de pontos de vista diversos, e a Teoria Gerativa limita-se a certos elementos, sendo o seu ponto de referência o da psicologia individual: "diz respeito aos aspectos da forma e do significado que são determinados pela Faculdade da Linguagem, que deve ser entendida como um componente particular da mente humana" (Chomsky, 1986 ${ }^{1}$ ). Assim, a teoria tem como objetivo a descoberta de princípios e elementos comuns às línguas humanas. Pode-se encarar a Faculdade da Linguagem (FL) como um dispositivo inato da mente humana que, pela interação com a experiência vivida, propicia a aquisição de uma língua particular. As três questões básicas que a investigação sobre esse conhecimento procura responder são (Chomsky, 1986: 23):

\footnotetext{
${ }^{1}$ Utilizamos a versão portuguesa, tradução de Anabela Gonçalves e Ana Teresa Alves; $O$ conhecimento da Língua: sua natureza, origem e uso. Lisboa: Caminho, 1994.
} 
(13) a. O que constitui o conhecimento da língua?

b. Como é adquirido o conhecimento da língua?

c. Como é usado o conhecimento da língua?

A primeira questão é respondida por uma Gramática Gerativa particular: a teoria se ocupa em investigar o estado da mente/cérebro de um indivíduo que conhece uma determinada língua, consistindo o conhecimento da língua no conhecimento de um determinado sistema de regras. A segunda questão é respondida por uma especificação da Gramática Universal (GU) e pela maneira como seus princípios interagem com a experiência, originando uma determinada língua. Conforme Chomsky (1986: 23), "a GU é uma teoria do estado inicial da faculdade da linguagem, anterior a qualquer experiência linguística". Nesse sentido, ao postular que a propriedade da mente humana descrita pela GU é uma característica da espécie, comum a todos os seres humanos (com exceção de casos patológicos), supõe o autor que o conhecimento linguístico deriva de um estado mental inicial $\left(\mathrm{E}_{0}\right)$ que se converte, com a experiência (aumento de provisão de regras ou modificação do sistema do indivíduo devido ao processamento de novos dados), num estado mental final relativamente estável $\left(\mathrm{E}_{\mathrm{E}}\right)$, então, sofre apenas modificações periféricas, como a aquisição de vocabulário. Dessa maneira, a FL é determinada por princípios internos uniformes para toda a espécie humana e por fatores externos, que correspondem ao input linguístico a que o indivíduo é exposto. A terceira questão teria como resposta uma teoria que investigue o modo como o conhecimento da língua interfere na expressão do pensamento e na compreensão das amostras de língua apresentadas, consequentemente, na comunicação e em outros usos especiais da língua, dividindo-se em duas partes: um problema de percepção e um problema de produção.

Para a Teoria Gerativa, a linguagem levanta uma questão análoga ao "problema de Platão", que é o problema da pobreza de estímulo: como dar conta da riqueza e complexidade do conhecimento, dadas as limitações da experiência? No caso da língua, diante da pobreza de evidências, como as crianças conseguem usar com segurança regras dependentes de uma estrutura computacionalmente complexa? Como conseguem, a partir de meios finitos, fazer uso infinito da língua?

Assim, a Teoria Gerativa parte da tese de que há uma estrutura mental inata (a hipótese do inatismo), que é um sistema de princípios gerais que restringem a variação possível entre as línguas e que guia a criança em fase de aquisição da linguagem. Segundo Lobato (1986), há controvérsias sobre o caráter inato da linguagem, mas Chomsky o defende de duas maneiras: 1) afirma que a língua é um sistema muito complexo e não há como 
explicar o fato de uma criança de 4 a 6 anos aprender a língua de sua comunidade sem postular uma faculdade inata de aquisição de língua; e 2) observa que a variedade entre línguas possíveis é bem limitada, compartilhando as línguas uma série de características relativas à sua organização fonética, semântica e morfossintática, sendo a espécie humana geneticamente marcada para usar seu aparelho vocal na comunicação, para utilizar construções lineares, para categorizar unidades e agrupar essas unidades em constituintes.

As capacidades linguísticas possuem, nessa perspectiva, domínios ilimitados, nos quais cada falante pode entender e produzir um número infinito de expressões linguísticas, apesar das limitações dos dados aos quais é exposto. Segundo Chomsky (2006: 53), Galileu pode ter sido o primeiro a reconhecer a propriedade da linguagem humana de fazer "uso de meios finitos para expressar uma vastidão ilimitada de pensamentos", mas Galileu referia-se à escrita alfabética; os filósofos de Port Royal deram mais um passo, refletindo sobre como a partir de 25 ou 30 sons podemos produzir uma infinidade de expressões que não têm qualquer semelhança com o que acontece em nossa mente. Charles Darwin também mostrou-se intrigado com essa propriedade da linguagem humana, afirmando que os cães pareciam estar no mesmo estágio de desenvolvimento que as crianças de 01 (um) ano de idade, que entendem diversas palavras e sentenças breves, mas não conseguem pronunciar palavras. Para Darwin (in Chomsky 2006: 55) "o homem difere apenas em seu poder quase infinitamente maior de associar os mais diversos sons e ideias". Para Chomsky (2006), a formulação de Darwin está, em alguns aspectos, equivocada, pois a propriedade da infinitude é apenas uma das muitas diferenças entre a linguagem humana e a linguagem dos outros animais, além de, atualmente, ter-se conhecimento de que as conquistas linguísticas da criança vão muito além do que supunha Darwin.

O cérebro de cada pessoa contém um léxico com seus respectivos conceitos e as regras para combinar as palavras de modo a transmitir informações. As regras que estabelecem as relações entre conceitos são o que chamamos de gramática, e seu design é um código autônomo em relação à cognição. Chomsky (2005) vai nomear operação de Concatenação (merge) a combinação entre as palavras. Para construir sentenças, também são necessários mecanismos de transformação, de deslocamento - a estes mecanismos Chomsky (2005) vai chamar operação Mover (move). Concatenar e mover são duas operações que, na relação com o léxico, são essenciais para explicar o funcionamento da língua.

No primeiro modelo chomskyano, não é dada nenhuma importância às propriedades semânticas. A consequência da exclusão do significado está no fato de que, neste modelo, se podem gerar cadeias anômalas: ao utilizar o léxico e relacionar palavras, poderiam ser 
formadas sentenças que, do ponto de vista da sintaxe, seriam perfeitas, mas, do ponto de vista semântico, não seriam bem formadas. Então, temos os conceitos de agramaticalidade e de aceitabilidade. Uma frase pode ser gramatical, mas inaceitável na língua:

(14) Pedro bebeu um prato de pão.

Os elementos desta oração estão combinados de maneira a saturar todos os argumentos solicitados pelo verbo, mas o argumento que preenche a função de objeto direto não possui o traço semântico exigido para o complemento do verbo beber: ser líquido. Isso demonstra que a sintaxe e o sentido podem ser independentes um do outro.

Para explicar a gramática combinatória, inicialmente, usou-se o mecanismo de cadeia de palavras, que consiste em "um grupo de listas de palavras (ou expressões pré-fabricadas) e um conjunto de direções para ir de uma lista para outra" (Pinker, 2002: 106). Chomsky refutou tal ideia e demonstrou que as cadeias de palavras constituem uma maneira equivocada de pensar sobre a língua. Para ele, uma frase funciona como uma árvore em que as palavras se agrupam em sintagmas e estes podem se reunir formando sintagmas maiores: a sentença. E, para que esse agrupamento seja feito, as pessoas, quando aprendem uma língua, sabem inconscientemente, que categorias lexicais seguem outras categorias. Sabem o que são as categorias e como elas se combinam. Essas categorias e essa maneira de combiná-las (sintagma) são universais e inatas.

Chomsky postula um aparato teórico para mostrar que as línguas funcionam com os princípios e os parâmetros, demonstrando que existem princípios universais e que os parâmetros vão constituir as diferenças entre as línguas. Para a linguística moderna "parece haver uma anatomia comum em todos os sintagmas de todas as línguas do mundo" (Pinker, 2002: 125). Os sintagmas contêm uma ordem inerente que tem muito em comum, pois tanto os nomes quanto os verbos constituem núcleos sintáticos que determinam as propriedades do sintagma que projetam.

Considerando os estados inicial e final, há dois problemas fundamentais para a Teoria Gerativa: determinar as propriedades do estado inicial, que correspondem aos princípios da GU e determinar as propriedades do estado final que a faculdade da linguagem atinge, tendo em vista a hipótese de que algumas características são opções abertas, os parâmetros, cujos valores são fixados na aquisição de língua, no contato com o input linguístico, e correspondem à variação translinguística. 
Assim, o modelo dos P\&P traz uma mudança notável e reflete avanços bem significativos para a Teoria Gerativa. Os princípios, universais, estão associados a parâmetros que são fixados pela experiência, no contato com o input linguístico da aquisição de língua. Dessa maneira, os parâmetros devem ter a propriedade de serem fixados por evidências simples, que estejam disponíveis para a criança. Por exemplo, a GU contém um princípio rígido que determina a existência da posição de sujeito nas línguas humanas, mas não determina que essa posição seja obrigatoriamente preenchida, com conteúdo fonético. Assim, algumas línguas são marcadas positivamente para este parâmetro (valor não pro-drop, para a realização fonética obrigatória) e outras não (valor pro-drop, para a realização fonética opcional do sujeito). Em português, podemos deixar essa posição vazia, não realizada foneticamente, mas em francês ou inglês, não (Raposo, 1992: 56):

(15) a. já chegaram da escola.

b. Ils sont déjà arrivés de l'école.

c. *__ sont déjà arrivés de l'école.

d. They already arrived from school.

e. *__ already arrived from school.

A diferença entre as línguas se dará também pela ordem dos termos na estrutura sintagmática, particularmente na posição entre o núcleo e seu complemento. Esse contraste é considerado um parâmetro, o qual prevê que o núcleo pode ser inicial ou final. Por exemplo, o valor do parâmetro em inglês pode ser determinado por sentenças como as que seguem abaixo, que indicam que se trata de uma língua do tipo 'núcleo inicial':
(16) a. John saw Bill
b. *John Bill saw

Assim, o Parâmetro do Núcleo pode ser marcado como [-/+final]. As línguas que possuem o núcleo anteposto ao complemento, são marcadas como Núcleo [-final], como o inglês e o português. Já as línguas que possuem o núcleo posposto a seu complemento, como o japonês, são marcadas como Núcleo [+final]. Desse modo, a ordem dos termos em uma oração transitiva no japonês é SOV, enquanto o português e o inglês manifestam a ordem SVO: 
(17) a. Português: Leda comprou doce

Ordem: $\quad \mathrm{S} \quad \mathrm{V} \quad \mathrm{O}$

b. Japonês: Leda okashi kau

Ordem: $\quad \mathrm{S} \quad \mathrm{O}$ V (dados extraídos de Kenedy, 2013: 107).

O curioso é que há regularidade nas diferenças e, além da ordem SVO ou SOV, o Parâmetro do Núcleo [-/+ final] implica um conjunto de propriedades sintáticas. Vejamos algumas propriedades, elencadas por Kenedy $(2013)^{2}$. Nas línguas em que a ordem predominante é sujeito-verbo-objeto, a tendência é que sejam preposicionais (18a); enquanto nas línguas em que a ordem é sujeito-objeto-verbo, existe uma tendência de que sejam posposicionais (ou seja, tem-se objeto-posposição), como ilustram os dados do Karajá, língua indígena brasileira, com parâmetro do núcleo [+final], em que o núcleo 'ò' (=para) é posposto ao seu complemento $\mathrm{N}(18 \mathrm{~b})$ :

(18) a. Português: Koboi foi para a roça.

b. Karajá: Koboi koworu ò rara.

'Koboi roça para foi. (dados extraídos de Kenedy, 2013: 108).

Na configuração sintática de expressões comparativas, as línguas [-final] posicionam a expressão comparativa antes do termo com o qual se compara algo (19a); enquanto as línguas [+final], (19b), posicionam a expressão comparativa "piaolian" (mais bonita) depois do termo usado para a comparação (o nome próprio Hua), como se pode verificar observando dados do português [-final] com dados do chinês [+final]:

(19) a. Português: Maria é mais bonita do que Ana.

b. Chinês: Mei bi Hua piaolian

'Mei do que Hua mais bonita'.

(dados extraídos de Kenedy, 2013:109)

\footnotetext{
${ }^{2} \mathrm{O}$ parâmetro da ordem é amplamente discutido na literatura e, particularmente, encontra-se sistematizado em vários manuais que abordam os fundamentos da Teoria Gerativa. Tendo em vista os objetivos desta seção em apresentar de forma sintética as bases teóricas em que se insere esta tese, utilizaremos a discussão formulada em Kenedy (2013) para o referido parâmetro.
} 
A ordem em relação ao nome de uma pessoa e o nome de família também será diferente. Em línguas de núcleo [-final], o nome de família ocorre depois do nome próprio; em línguas de núcleo [+final] o nome de família vem primeiro:

(20) a. Português: João da Silva

b. Chinês: Chang Whan (Whan pertence à família Chang)

(dados extraídos de Kenedy, 2013: 109).

Em línguas de núcleo [-final], o nome, tipicamente, ocorre antes do adjetivo; enquanto em línguas de núcleo [+final], o adjetivo ocorre preposto ao nome. Assim, em línguas em que se diz "João da Silva", também se diz "casa grande"; enquanto línguas em que se diz "Chang Whan”, também se diz "ta fenzi” (grande casa, no sentido denotativo):

(21) a. Português: casa grande (nome + adjetivo)

b. Chinês: ta fenzi (adjetivo + nome)

'grande casa' (dados extraídos de Kenedy, 2013: 109).

Os adjetivos genitivos (ou a locução adjetiva genitiva), que indicam a posse de um determinado objeto em relação a alguém ou algo, ficam pospostos ao substantivo sobre o qual a posse é indicada em línguas de núcleo [-final], em português, por exemplo, dizemos "casa de João", mas não *“de João casa”; nas línguas de núcleo [+final], a expressão genitiva é preposta ao substantivo.

As orações relativas em línguas de núcleo [-final] são pospostas ao nome que modificam; nas línguas de núcleo [+final], ocorrem antepostas ao nome modificado:

(22) a. Português: A loja que Kato comprou.

[nome] [oração relativa]

b. Japonês: Kato-ga Katta mise

[oração relativa] [nome]

'Kato comprou (que) loja'

(dados extraídos de Kenedy, 2013: 110). 
Os advérbios de negação ocorrem antes do verbo em línguas de núcleo [-final] ${ }^{3}$ e depois do verbo em línguas de núcleo [+final], como podemos verificar no contraste entre o português e o apinayé (língua indígena brasileira, de núcleo [+final]):

(23) a. Português: O livro que você não leu.

b. Apinayé: Pa krerket ne

'Eu comi não' ～(dados extraídos de Kenedy, 2013: 110).

Por fim, a posição do verbo auxiliar também será diferente: em línguas de núcleo [final], o verbo auxiliar virá antes do verbo principal, enquanto em línguas de núcleo [+final], virá depois:

(24) a. Português: Eu fui pescar.

$$
\text { [auxliar] [principal] }
$$

b. Karajá: Deary waximy rare.

[principal] [auxiliar]

'Eu pescar fui’ （dados extraídos de Kenedy, 2013: 111).

O conjunto de propriedades sintáticas decorrente da marcação do Parâmetro do Núcleo [-/+ final $]$ é resumido pelo autor no quadro abaixo (cf. Kenedy 2013: 108):

\footnotetext{
${ }^{3} \mathrm{O}$ autor ressalta que, em muitos dialetos do português brasileiro, encontram-se variantes em relação à posição do advérbio de negação, pois há brasileiros que dizem "não comi", mas também há os que dizem "comi não". Além da possibilidade da dupla negação: "não comi não" (Kenedy, 2013: 110).
} 


\begin{tabular}{|c|c|c|}
\hline & \multicolumn{2}{|c|}{ Padrão } \\
\hline Estrutura & [+final] & [-final] \\
\hline 1. Ordenação de orações & & \\
\hline 1.1 Posição entre $\mathrm{O}$ e V & OV & VO \\
\hline 1.2 Adposição & posposição & preposição \\
\hline 1.3 Construções termo-padrão & & \\
\hline 1.3.1 Comparativos & termo padrão - adjetivo & adjetivo - termo padrão \\
\hline 1.3.2 Nome de família & família - pessoa & pessoa - família \\
\hline 2. Modificadores do nome & & \\
\hline 2.1 Adjetivos descritivos & adjetivo - nome & nome - adjetivo \\
\hline 2.2 Adjetivos genitivos & genitivo - nome & nome - genitivo \\
\hline 2.3 Orações relativas & oração relativa - nome & nome - oração relativa \\
\hline 3- Modificadores do verbo & & \\
\hline 3.1 Negação & verbo - advérbio negativo & advérbio negativo - verbo \\
\hline 3.2 auxiliares & verbo - auxiliar & auxiliar - verbo \\
\hline
\end{tabular}

A regularidade na realização sintática das categorias encontra-se originalmente sistematizada nos estudos tipológicos, como o de Joseph Greenberg, tendo sido essencial para a sustentação da Teoria X-barra, que é um modelo de projeção sintagmática válido para todos os sintagmas de todas as línguas. Nesse modelo, é possível ainda prever as duas possibilidades de ordem - com núcleo inicial ou final. Assim, para obter português, a informação é de que o núcleo é inicial; para obter japonês, a informação é de que o núcleo é final, conforme apresentado anteriormente.

Chomsky (2005) compara o funcionamento da marcação dos valores paramétricos ao funcionamento de um quadro de interruptores. O quadro seria o estado inicial da faculdade da linguagem. Os interruptores seriam as possibilidades determinadas pela experiência. Se acionarmos os interruptores de uma determinada maneira, teremos a língua $\mathrm{X}$; se acionarmos de outra maneira, teremos a língua Y, como vimos com a ilustração do Parâmetro do Núcleo [-/+ final]; e assim por diante. Cada língua poderia ser identificada como um conjunto específico de interruptores - os parâmetros. Funcionando dessa forma, a criança, para aprender uma língua, não necessita aprender uma longa lista de regras, uma vez que os princípios são universais e inatos. O que ela precisa é aprender o valor dos parâmetros que caracterizam a língua a que é exposta: por exemplo, núcleo inicial (português) ou núcleo final (japonês); é como se ela tivesse apenas que escolher entre posições possíveis de um interruptor. 
O sistema está operativo logo que os valores dos parâmetros estejam fixados, isto é, "o sistema está associado a um conjunto finito de interruptores, possuindo cada um destes um número finito de posições (talvez duas). Exige-se experiência para regular os interruptores. Quando estiverem regulados, o sistema funciona" (Chomsky, 1986: 153).

Essa abordagem é adotada no âmbito do Programa Minimalista, no qual se propõe investigar a Faculdade da Linguagem do ponto de vista do questionamento quanto à sua arquitetura, no que se refere a um critério de 'perfeição' no atendimento às exigências dos sistemas com os quais faz interface - o sistema articulatório-perceptual e o sistema lógicointencional - em que se investiga a hipótese de que, o sistema é ótimo. Para explicar o que é um sistema ótimo, Chomsky (2006: 131) faz uma analogia com a estrutura corporal: o fígado pode ser otimamente projetado para interagir com o sistema circulatório e os rins e assim por diante; no entanto, não é bem projetado para uma vida na Itália, onde as pessoas tomam muito vinho e desenvolvem muitas doenças do fígado. Partindo de tal analogia, um sistema ótimo, do ponto de vista da teoria gerativa, não se refere a um sistema projetado para o seu uso, pois, se fosse esse o caso, aparentemente, não seria um sistema ótimo, uma vez que no uso da linguagem há ambiguidades, sentenças ininteligíveis, sentenças que são inteligíveis, porém não são bem formadas etc. Nesse sentido, o sistema não é otimamente projetado para o uso, mas é bem projetado o suficiente para continuar a existir. Assim, a linguagem humana é um sistema ótimo na perspectiva de sua relação com sistemas que estão dentro da mente.

\subsubsection{Língua Externa (Língua-E) x Língua Interna (Língua-I)}

$\mathrm{Na}$ concepção gerativista, o conhecimento da linguagem é individual e interno à mente/cérebro humano. Assim, o estudo da linguagem precisa tratar de seu constructo mental. A essa entidade teórica, Chomsky (1986) denominou Língua-I (interna), em oposição à Língua-E (externa). A Língua-E é constructo compreendido independentemente das propriedades da mente/cérebro. Nesse âmbito, podemos pensar na noção de língua como um conjunto de ações ou comportamentos. Assim, uma gramática da Língua-E é uma coleção de afirmações descritivas em relação a atos linguísticos (e/ou produções linguísticas) reais ou potenciais, que podem ser acompanhados de uma análise do seu contexto de uso ou de seu conteúdo semântico.

A Língua-I refere-se à existência de uma noção de estrutura na mente do falanteouvinte, que é suficiente para guiar na estruturação das frases, particularmente, nas expressões livres que podem ser novas para o falante e para o ouvinte. A Língua-I é, então, "um componente que existe na mente da pessoa que conhece a língua, adquirido por quem 
aprende, e usado pelo falante-ouvinte" (Chomsky, 1986: 41). Em relação a esse componente, as afirmações de uma gramática são afirmações que remetem a uma teoria da mente acerca da língua-I. A GU é "construída como a teoria das línguas-I humanas, um sistema de condições que deriva do equipamento biológico humano que identifica as línguas-I que são humanamente acessíveis em condições normais" (Chomsky, 1986: 43). Numa hipótese empírica inicial, a língua-I é um sistema de regras, uma realização específica das opções permitidas pela GU, fixadas pela experiência.

A Teoria Gerativa, então, tem como foco a língua-I, o sistema de conhecimento que sustenta o uso e a compreensão da língua, a capacidade inata que permite aos seres humanos alcançarem tal conhecimento. Dessa maneira, seu objeto de estudo precisa ser um falanteouvinte ideal, situado em uma comunidade linguística homogênea, que conhece sua língua. Esse falante-ouvinte ideal não é afetado por condições externas, como distrações, limitações de memória, desvios de atenção, interesses, erros, etc. (Raposo, 1992). Nesse sentido, a Teoria Gerativa busca representar o que um indivíduo sabe quando sabe uma língua.

\subsubsection{O Programa Minimalista}

O Programa Minimalista (PM) (Chomsky, 1995) parte do modelo dos Princípios e Parâmetros (P\&P) (Chomsky, 1986), tal como formulado na teoria da Regência e Ligação (Government and Biding $(G B)$ ). No modelo GB, a GU consiste em vários subsistemas, como a teoria da ligação, a teoria temática, a teoria X-barra, a teoria do Caso, a teoria dos nósfronteira, "que trata de condições de localidade sobre o movimento e outras, contendo cada uma delas certos princípios com um grau limitado de variação paramétrica” (Chomsky, 1986: 113).

Os desenvolvimentos da pesquisa conduziram a reformulações em alguns pressupostos. Apesar de o modelo de P\&P representar um avanço na Teoria Gerativa, em relação à Teoria Padrão Alargada ${ }^{4}$, percebeu-se a necessidade de, para uma adequação explicativa e para uma adequação descritiva, reformular os pressupostos da teoria, no que se refere aos fundamentos metodológicos e às propriedades da GU. Assim, o PM investiga

\footnotetext{
${ }^{4}$ Segundo Raposo (1992: 53), a Teoria Standard Alargada trabalha com uma gramática que "contém um número distinto e autônomo de componentes, cada uma delas com uma organização própria caracterizada por um pequeno número de regras e por princípios que restringem a aplicação dessas regras. Existe uma componente lexical, uma componente das regras de base, uma componente transformacional, uma componente para a interpretação de pronomes e anáforas, e assim sucessivamente". Não nos aprofundaremos aqui, mas sugerimos a leitura de Chomsky 1970 para interessados.
} 
aspectos fundamentais da arquitetura do modelo $\mathrm{P} \& \mathrm{P}$, removendo tudo aquilo que não é necessário. O PM tem como motivação duas questões relacionadas (Chomsky, 19955: 39):

(25) Que condições gerais esperamos que a Faculdade da Linguagem (FL) humana satisfaça?

(26) Até que ponto a FL é determinada por estas condições, sem qualquer outra estrutura adicional para além delas?

Nesse sentido, o PM atribui uma importância particular ao lugar e ao papel da linguagem na mente humana. A FL é um sistema biológico que se adapta a uma tarefa que permite que o ser humano possa falar sobre o mundo, referir-se a algo no mundo, indagar sobre algo, exprimir-se, comunicar-se, persuadir, enfim, utilizar-se da língua de acordo com suas intencionalidades. Esse conjunto de intencionalidades compõe o sistema ConceptualIntencional (CI). A FL associa-se também a um sistema externo de produção (sistema vocálico-articulatório-manual) e recepção (sistema de percepção neuro-auditivo-visual), chamados sistemas sensório-motores, que compõem o sistema Articulatório-Perceptual (AP). Nos níveis de interface, a FL precisa associar cada um dos sistemas de performance: o sistema CI e o sistema AP. O sistema cognitivo interage, então, com os dois sistemas externos: o sistema articulatório-perceptual (AP) e o sistema conceptual-intencional (CI). Assim, temos dois níveis de interface: a Forma Fonética (PF) na interface com AP, e a Forma Lógica (LF) na interface com CI. Essa propriedade de interface dupla, para Chomsky (1995: 40), "é um modo de exprimir a caracterização tradicional da linguagem como sendo som acompanhado de significação, uma visão que remonta pelo menos a Aristóteles”.

\subsubsection{O léxico e o sistema computacional}

O Programa Minimalista considera que a língua L é formada por dois componentes: o léxico, entendido como repositório de exceções, não sendo uma consequência de princípios gerais, e um sistema computacional, que usa os elementos do léxico para gerar derivações e descrições estruturais (DEs) ${ }^{6}$. Assim, “cada língua determina um conjunto de pares $(\pi, \lambda)(\pi$ retirado do vocabulário de $\mathrm{PF}$ e $\lambda$ retirado do vocabulário de LF). Estes pares constituem

\footnotetext{
${ }^{5}$ Utilizamos a versão traduzida para o português: O Programa Minimalista. Tradução, apresentação e notas à tradução de RAPOSO, Eduardo. Lisboa: Editorial Caminho, 1999.

${ }^{6}$ Descrições estruturais são expressões linguísticas.
} 
representações formais de som e de significado dessa língua" (Chomsky, 1995: 245). Sendo cada DE um par $(\pi, \lambda)$, pressupõe-se que uma derivação $\mathrm{D}$ pode convergir ou não. A derivação converge, se produz uma DE legítima; e fracassa, se produz uma DE não legítima.

Porém, não basta que uma expressão linguística seja formada por uma derivação convergente. A derivação precisa ser ótima, no sentido de que o par $(\pi, \lambda)$ está sujeito à Interpretação Plena (Full Interpretation - FI), um princípio de economia representacional que requer que todos os traços deste par sejam legíveis em ambas as interfaces (PF e LF). Assim, a derivação converge se, e somente se, converge tanto na LF quanto na PF. Então, se D é um conjunto de derivações permitidas, o conjunto de derivações convergentes C é um subconjunto de D do qual os membros satisfazem FI na LF e na PF, isto é, o conjunto de objetos sintáticos legíveis é um subconjunto do conjunto de todas as combinações que a gramática pode construir, como podemos visualizar no esquema abaixo, apresentado em Hornstein et al (2005: 16):

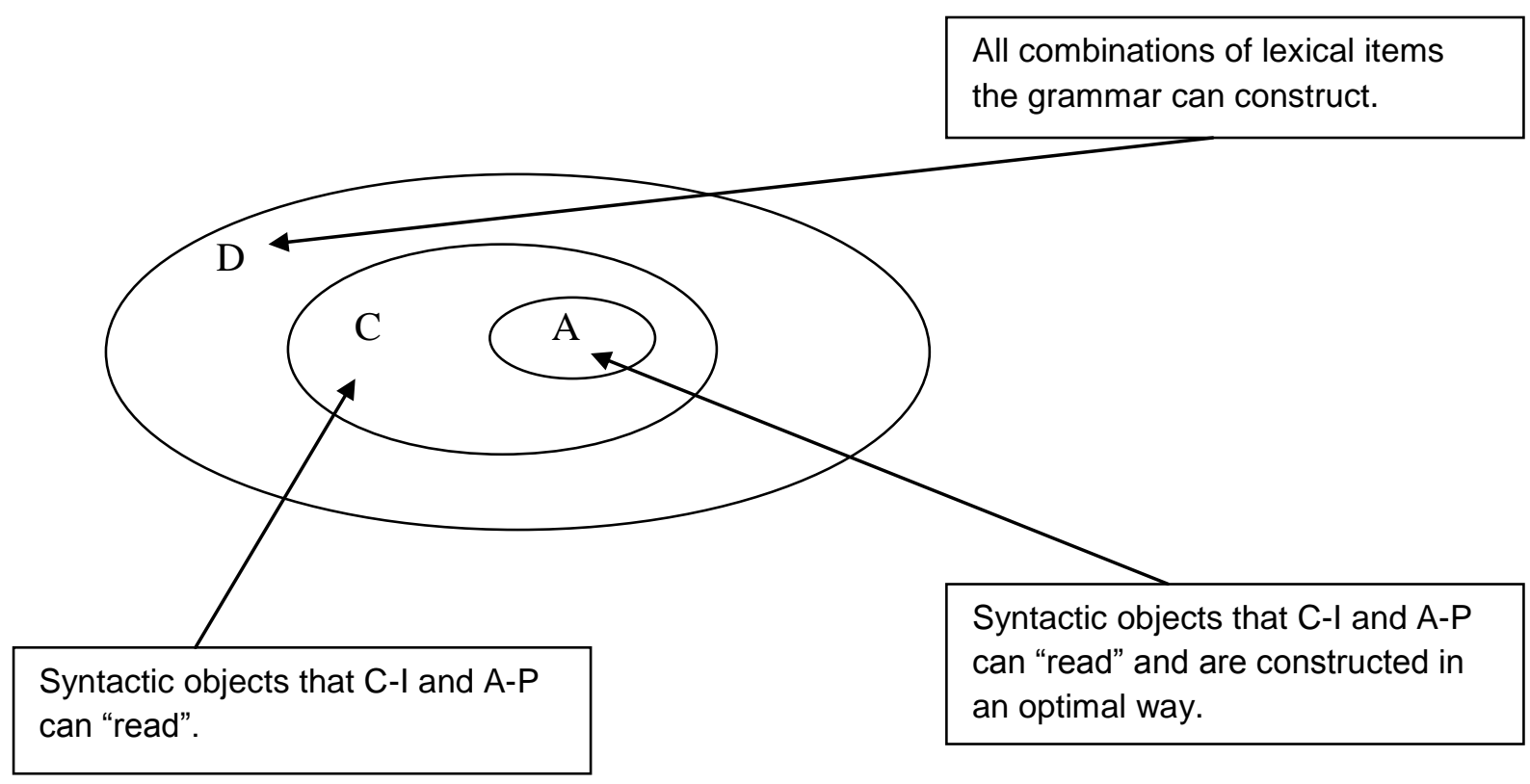

Na caracterização do léxico, Chomsky (1995: 75) distingue categorias substantivas e funcionais, adotando, entre outros, o critério de que aquelas, mas não estas, têm caráter predicativo, propondo ainda que as categorias do léxico se constituem de feixes de traços semânticos, formais e fonológicos. Em relação às categorias substantivas, propõe o sistema de combinação dos traços [+/-N] e [+/-V], o que permite identificar quatro possibilidades lógicas, as quais correspondem às categorias nome $(\mathrm{N})$, verbo $(\mathrm{V})$, adjetivo $(\mathrm{A})$ e preposição $(\mathrm{P})$ : 
(27) a. $\mathrm{N}=[+\mathrm{N},-\mathrm{V}]$

b. $\mathrm{V}=[-\mathrm{N},+\mathrm{V}]$

c. $\mathrm{A}=[+\mathrm{N},+\mathrm{V}]$

d. $\mathrm{P}=[-\mathrm{N},-\mathrm{V}]$

Quanto às categorias funcionais, Chomsky (1995) observa que desempenham um papel essencial, por serem responsáveis por ativar as operações do sistema computacional, manifestando traços (não-interpretáveis) de pessoa/ gênero/ número, a serem validados, em um domínio de busca, por traços correspondentes interpretáveis. A definição do inventário das categorias funcionais conduz à eliminação dos núcleos funcionais AgrS e AgrO (originalmente propostos como licenciadores de DP na função de sujeito e objeto, respectivamente), sob o argumento de que se sustentariam apenas por exigência interna da teoria, não manifestando aporte conceitual próprio. Com isso, passa-se a contar com: C (força/ modo), T (tempo/ estrutura do evento), v (verbo leve) e D (referencialidade), ficando o licenciamento de DPs na posição de sujeito e de objeto associados respectivamente a T e v.

Os traços primitivos constituem a sequência terminal de um indicador sintagmático. São, portanto, núcleos que projetam operações do sistema computacional. São projeções máximas aqueles elementos que não projetam mais. Assim, XP é a projeção máxima de uma categoria X. A dominância e a linearidade são duas relações básicas de um indicador sintagmático. Ilustrando a relação de dominância, em (28), B domina D e E, C domina F e G, e A domina todas as outras categorias. Quanto à relação de linearidade, observa-se que B precede C, F e G; D precede E, C, F e G; e assim por diante (Chomsky, 1995:75):

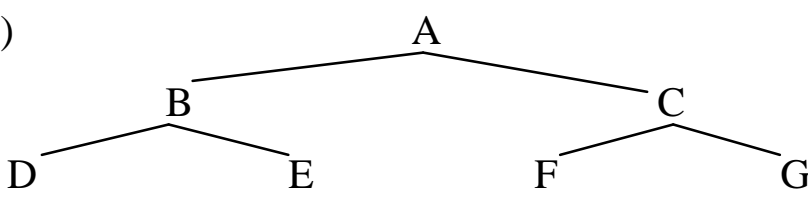

Sendo X um núcleo, terá como nó “irmão” o seu complemento. Considerando uma língua de Parâmetro do Núcleo [-final], como o português, em (28), se D e F são núcleos, E e G são, respectivamente, seus complementos.

A vinculação sintática que se estabelece entre dois constituintes é uma relação fundamental que se aplica em todos os módulos da gramática e denomina-se comando. $\mathrm{Na}$ 
relação de comando, um constituinte c-comanda ${ }^{7}$ e outro é c-comandado. Dizemos que $\alpha$ ccomanda $\beta$ se não domina $\beta$ e todo o $\mathrm{V}$ que domina $\alpha$ domina $\beta$. Considerando a estrutura em (28), podemos dizer que B c-comanda C, F e G; C c-comanda B, D, E; D c-comanda E e conversamente; F c-comanda G e conversamente.

O sistema computacional envolve as seguintes operações: Selecionar (Select), concatenar/compor (Merge) e Mover (Move). A operação Selecionar é um procedimento que seleciona um item lexical da numeração, reduzindo o seu índice de 1, e o introduz na derivação mediante a operação Merge, que forma um objeto sintático a partir de dois itens, e unidades maiores a partir daquelas já construídas, pois uma derivação só converge se esta operação se aplicar tantas vezes quantas forem necessárias. "Se Selecionar não esgotar a numeração, nenhuma derivação é gerada e não surgem questões de convergência ou de economia. A aplicação insuficiente de Compor tem a mesma propriedade" (Chomsky, 1995: 315). A operação Merge é assimétrica, projetando $\alpha$ ou $\beta$, e o núcleo do objeto que projeta converte-se no rótulo do complexo formado, conforme se observa na representação arbórea a seguir:

(29)

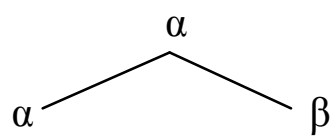

$\mathrm{Na}$ construção de uma estrutura, participa outra operação que forma categorias: a operação Mover. Suponhamos que temos a categoria $\Sigma$ com os termos K e $\alpha$. Pode-se formar $\Sigma$ ' elevando $\alpha$, que toma $\mathrm{K}$ como alvo. Esta operação substitui $\mathrm{K}$ em $\Sigma$ por $\mathrm{L}=\{\mathrm{Y},\{\alpha, \mathrm{K}\}\}$ (Chomsky: 1995: 343):

(30) a.

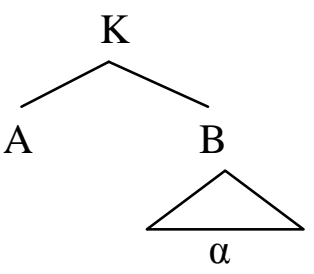

b.

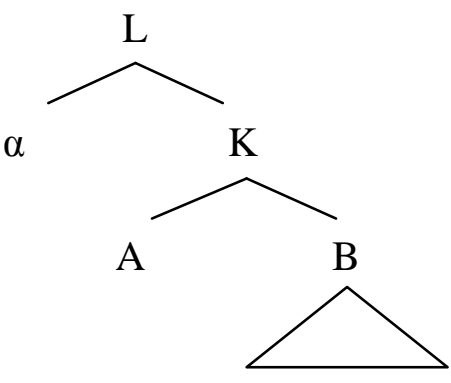

${ }^{7}$ c-comando: a

$\mathrm{t}(\alpha)$ 
Quando Mover forma uma cadeia $(\alpha, \mathrm{t}(\alpha))$, certas condições devem ser obedecidas. A primeira delas é a condição do c-comando: $\alpha$ tem de c-comandar o seu vestígio. Não pode haver uma operação que abaixe $\alpha$ ou mova-o lateralmente, todo o movimento é elevação; uma segunda condição é que as cadeias satisfaçam a condição de uniformidade, em que o estatuto de estrutura de constituintes é a sua propriedade de ser máximo, mínimo ou nenhum dos dois; uma terceira condição é que Mover satisfaça a condição do Último Recurso sobre o movimento: ser determinado morfologicamente, pela necessidade de verificar algum traço (Último Recurso). O Último Recurso pode ser interpretado da seguinte maneira (Chomsky, 1995: 353):

(31) $\alpha$ pode tomar K como alvo apenas se

a. um traço de $\alpha$ é verificado pela operação;

b. um traço de $\alpha$ ou um traço de K é verificado pela operação;

c. a operação é um passo necessário para alguma operação seguinte na qual um traço de $\alpha$ é verificado.

A verificação de traços é uma propriedade central do sistema computacional. Tratase de uma operação que determina o movimento com base na condição do Último Recurso, que é uma tentativa de captar de modo preciso a ideia de que o movimento é determinado por exigências de verificação morfológica. Assim, a verificação é reduzida ao apagamento de traços: um traço verificado é marcado como invisível na interface.

Dado um item lexical como 'avião', os traços que aparecem na entrada lexical são de três tipos: traços fonológicos, como 'começa com vogal', traços formais, como $[ \pm \mathrm{N}]$ e [ \pm plural], acessíveis no decurso da computação de $\mathrm{N} \rightarrow K$; os traços semânticos, como ‘artefato', que não são acessíveis, pois não há operações do sistema computacional sobre traços semânticos. Assim, os traços formais do item lexical 'avião' são a coleção de traços que funcionam na computação de $\mathrm{N} \rightarrow K$, excluindo-se traços fonológicos e puramente semânticos. Alguns traços são intrínsecos ao item lexical, como o traço categorial, o traço de pessoa e o traço de gênero; outros são opcionais, como os traços não-categoriais de número e de Caso, acrescentados no momento em que o item lexical entra na numeração.

Na versão da Teoria da Regência e Ligação, o Caso é atribuído por uma categoria (funcional ou lexical) em uma configuração de regência. No Programa Minimalista, elementos nominais entram na derivação com um traço de Caso a ser valorado em um domínio de busca para a operação Agree, definido por um núcleo funcional. Agree estabelece 
uma relação entre um elemento Sonda e um elemento Alvo. Essa relação é determinada pela presença de traços formais não-interpretáveis em um núcleo funcional. Um núcleo $\mathrm{X}$ com traços não-interpretáveis (Sonda) escaneia seu domínio de c-comando procurando por outro elemento (Alvo) com traços interpretáveis correspondentes, com o qual vai concordar (Agree). Os traços formais de pessoa, número e gênero são uma coleção, referida como traços phi $/ \phi$. Esses traços estão associados à operação Agree, por meio da qual ocorrem a checagem de traços de concordância (traços- $\Phi$ ) e a valoração dos traços de Caso. O valor (interpretável) do elemento Alvo é atribuído ao elemento Sonda.

A depender da categoria funcional envolvida, será valorado o Caso nominativo ou acusativo - respectivamente no domínio de busca de T e v. O elemento selecionado do léxico a ser inserido no terminal da estrutura sintática deve, portanto, manifestar os traços morfofonológicos de acordo com o Caso licenciado. Para ilustrar essa operação, Hornstein et al, (2005: 286-287) apresentam um exemplo simples, em que se verifica a correspondência dos traços e a falta de correspondência:

(32) a. [TP she $_{i}\left[T, T^{0}\right.$ [vp was seen $\left.\left.\left.t_{i}\right]\right]\right]$.

$$
\text { ' } \left.\left[\mathrm{TP}_{\mathrm{P}} \mathrm{ela}_{\mathrm{i}}\left[\mathrm{T}, \mathrm{T}^{0} \text { [vP foi vista } \mathrm{t}_{\mathrm{i}}\right]\right]\right]
$$

b. *[тр $\operatorname{her}_{\mathrm{i}}\left[\mathrm{T}, \mathrm{T}^{0}\left[\mathrm{vP}\right.\right.$ was seen $\left.\left.\left.\mathrm{t}_{\mathrm{i}}\right]\right]\right]$.

Assim, o uso alternado de 'she' e 'her' em (32a, b) mostra que os elementos entram na derivação com seus traços morfofonológicos de Caso especificados e são inseridos em Spec, TP. Sendo T finito associado ao Caso nominativo, 'she', que é marcado morfologicamente em inglês para o caso nominativo, pode ter seu traço de Caso checado nessa configuração, mas 'her' não; o contraste entre 'she' e 'her' acima demonstra que 'her' não tem seu traço de Caso checado, o que faz a derivação fracassar.

Quanto à estrutura, assume-se que os objetos sintáticos são de dois tipos: (i) itens lexicais (feixes de traços listados no léxico); (ii) objetos do tipo $\mathrm{K}$, formados a partir de objetos do tipo (i), como um par ordenado, em que um dos elementos projeta e fornece o rótulo para $\mathrm{K}$, conforme: $\mathrm{K}=\{\alpha\{\alpha, \beta\}$. Assim, uma categoria do tipo (ii) é uma projeção de um núcleo, o qual é retirado do léxico, sendo 'complemento' e 'especificador' relações com um dado núcleo - como em (33), em que núcleo-complemento é a relação mais local de YP com X, e as demais relações dentro de XP são especificador-núcleo (não havendo restrição a múltiplos especificadores) (Chomsky, 1995: 249): 
(33)

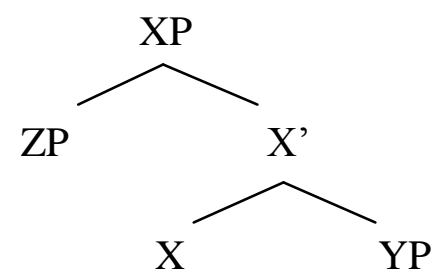

A relação núcleo-complemento não é apenas mais local, mas também mais fundamental por ser geralmente associada às relações temáticas. Chomsky (1995), reelaborando a teoria de Pollock (1989 apud Chomsky, 1995) sobre a flexão, propõe a estrutura básica da oração transitiva, ilustrada em (34), em que sujeito e objeto verificam seus traços em relação a T e v, respectivamente ${ }^{8}$ (Hornstein et al, 2005: 133):

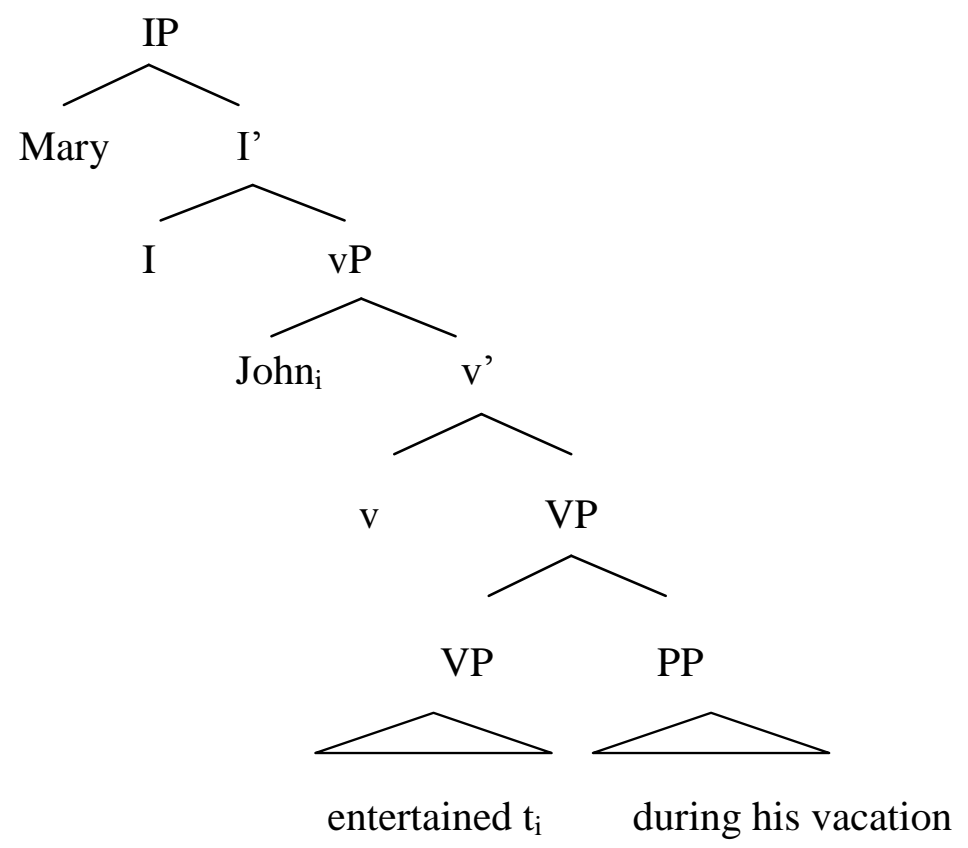

Por fim, são as seguintes conclusões relacionadas ao Programa Minimalista que têm sido levadas a cabo com sucesso (Chomsky, 1995: 299):

a) Uma expressão linguística (DE) é um par $(\pi, \lambda)$, gerado por uma derivação ótima que satisfaz as condições de interface;

\footnotetext{
${ }^{8}$ Em Chomsky (1995), AgrS e AgrO, presentes em versão anterior da teoria, são excluídos, porque, diferentemente das demais categorias funcionais, sua presença se justifica apenas por razões internas à teoria. $\mathrm{O}$ especificador de TP ([Spec, TP]), omitido em Chomsky (1995: 250), diante da opcionalidade do movimento aberto do sujeito, está projetado por razões descritivas. Mantivemos omitido o elemento funcional Neg(ação).
} 
b) Os níveis de interface são os únicos níveis da representação linguística;

c) Todas as condições exprimem propriedades dos níveis de interface e refletem exigências interpretativas;

d) A GU providencia um sistema computacional único, em que as derivações são determinadas por propriedades morfológicas; e a variação sintática entre as línguas restringe-se às propriedades morfológicas;

e) A noção de economia recebe uma interpretação bastante restrita em termos dos seguintes princípios: o princípio da interpretação plena (Full Interpretation - FI), comprimento de uma derivação, comprimento dos elos de uma cadeia, Procrastinar e Cobiça.

\subsection{Considerações parciais}

Neste capítulo, fazemos uma breve exposição sobre o desenvolvimento da noção de categoria lexical ou classe de palavra, na tradição gramatical, remontando à contribuição dos filósofos gregos. Nesta exposição, discutimos o estudo das categorias, principalmente dos advérbios, de filósofos como Platão e Aristóteles até gramáticos como Dionísio o Trácio. Constatamos a herança helenística da gramática tradicional quanto às categorias, mas principalmente, quanto à definição dos advérbios que mantém a sua essência: palavra invariável, que acompanha essencialmente o verbo. Assim, retomamos a contribuição da GT, demostrando que a distinção das categorias foi objeto de análise desde os primeiros estudos mas, ao mesmo tempo, ressaltamos que os autores não se preocuparam diretamente com os problemas colocados pelos dados apresentados e pelas questões formuladas nesta tese. Ou seja, não havia preocupação em destacar as limitações da classificação. Testando alguns dados, percebe-se rapidamente a capacidade dos advérbios de modificarem categorias diversas, lexicais e funcionais. Assim, a linguística vai ser o campo que discutirá as questões do ponto de vista das contradições e das limitações da classificação tradicional, buscando extrair dos dados novas categorias ou novas formas de abordar as classes de palavras.

Na discussão, apresentamos a abordagem de Câmara Jr. (1979), que divide essa categoria em formas nominais (por assinalarem o modo de ser, podendo ser chamados de modais) ou pronominais (por indicarem referência, podendo ser locativos e temporais); aponta o uso de advérbios como conectores e ressalta as dificuldades em caracterizar as palavras que compõem essa categoria. Expusemos também os critérios elencados por Câmara Jr. (2004) para categorizar uma palavra em uma língua. Partindo dos critérios propostos pelo autor, levantamos alguns fenômenos como a flutuação categorial, o uso pronominal de advérbios e 
sua ocorrência em posição de argumento. Tais fenômenos demonstram comportamentos sintáticos e semânticos distintos dessas palavras, que justificam as dificuldades em caracterizar a categoria. Essa dificuldade origina as questões deste trabalho, elencadas em nossa introdução.

Para investigar as propriedades dessa categoria, propusemos como base a Teoria Gerativa, que se propõe descrever e explicar os fatos da língua, buscando a formalização das propriedades identificadas em termos dos pressupostos da Gramática Universal. Desse modo, a seção 1.2 sistematizou os principais pressupostos da Teoria Gerativa.

Nessa discussão, demonstramos que o modelo da GU consiste de operações associadas a categorias que entram em operações de verificação ou identificação de traços formais, em domínios sintáticos específicos. Essas operações podem ser referidas informalmente como operações de concordância, em configurações estruturais, que envolvem a realização de constituintes em diferentes posições sintáticas, com consequências para a ordem dos termos na oração e em consonância com as propriedades inerentes às diferentes categorias sintáticas. Perguntamo-nos então de que maneira a categoria advérbio pode ser afetada por tais operações. Passamos, portanto, a discutir nos próximos capítulos aspectos da sintaxe dessa categoria, tendo como referência o modelo da GU, conforme descrito nesta seção. 


\section{CAPÍTULO 2 \\ ADVÉRBIOS: O ESTATUTO CATEGORIAL}

Em nossa introdução, levantamos questões relacionadas ao estatuto da categoria advérbio, que guiarão o desenvolvimento deste trabalho. Neste capítulo, partimos da constatação de que os elementos que compõem a classe dos advérbios compartilham propriedades, mas também manifestam diferenças significativas, que apontam para o caráter não uniforme da classe e para a existência de subclasses, que nos propomos investigar.

Para tanto, o capítulo está estruturado da seguinte maneira: na seção 2.1, discutiremos as relações entre advérbios e preposições, envolvendo os estudos de Lemle (1984), Bomfim (1988) e Lobato (1989), que discutem a possibilidade de advérbios pertencerem ou não à classe das preposições; na seção 2.2, retornamos ao estudo de Bomfim (1988), mas observando a análise que diz respeito ao compartilhamento de propriedades entre advérbios e pronomes. Nesta discussão, a autora relaciona tais propriedades à possibilidade de advérbios locativos e temporais ocuparem a posição de sujeito; por fim, na seção 2.3, trazemos o estudo de Lobato (2008) que discute a hipótese da flutuação categorial entre advérbios e adjetivos, concluindo que não há flutuação categorial, que cada categoria possui um conjunto de propriedades que lhe permite determinada distribuição sintática. Recorremos ainda ao estudo de Leung (2007) ${ }^{9}$, que busca refinar a proposta de Lobato (2008), demonstrando que as estruturas propostas ocorrem com verbos que denotam atividade e que possuem uma semântica de produção, licenciando um objeto cognato eventivo. Em seguida, fazemos uma breve exposição dos motivos pelos quais Foltran (2010) reavalia a proposta de Lobato (2008) e postula que advérbios e adjetivos podem alternar entre a predicação de indivíduos ou a predicação de eventos, evitando assumir uma mudança de categoria quando há um adjetivo predicando de evento.

Os debates sobre as propriedades compartilhadas ou não entre advérbios e preposições, advérbios e pronomes, advérbios e adjetivos nos permitem perceber mais claramente as propriedades dos advérbios e a refletir sobre quais delas permitem aos advérbios ocupar posições diversas, entre elas, a posição de sujeito.

\footnotetext{
${ }^{9}$ Leung (2007) trabalha com a hipótese de Lobato (2008), no entanto, com uma versão do trabalho não publicada, apresentada no V Workshop 'Formal Linguistics at USP' em 2005.
} 


\subsection{Advérbios e preposições: um diálogo entre Lemle (1984), Bomfim (1988) e Lobato} (1989)

Retomando o estatuto dos advérbios e das preposições na tradição gramatical, Lemle (1984) faz uma reflexão sobre as propriedades de cada uma dessas classes, demonstrando que os advérbios podem ser uma subclasse das preposições. A autora explica que, na tradição gramatical, para dar nome às locuções formadas com preposição, adotam-se os seguintes critérios: a) se uma preposição seguida de um nome estiver em posição equivalente à posição de um advérbio, como (1a), deve ser chamada locução adverbial; b) se a mesma sequência estiver na posição equivalente a de um adjetivo, como (1b), será chamada locução adjetiva.

(1) a. Chegou a cavalo.

b. Um homem a cavalo.

Para Lemle (1984), esses critérios colocados pela tradição gramatical obedecem a um princípio no qual uma locução recebe seu nome em termos da função que exerce dentro da estrutura, o que nomeia rotulação funcional. Contudo, a autora ressalta que existe outro princípio, mais utilizado nas descrições linguísticas mais recentes, no qual uma locução é nomeada de acordo com a classe gramatical de seu termo nuclear. Assim, temos em (2) um sintagma adverbial, pois é o advérbio o núcleo da construção:

(2) Independentemente desse argumento.

De acordo com esse princípio, pode-se dizer que a cavalo (1a) e (1b) é um sintagma preposicional. Esse segundo princípio de nomenclatura é denominado rotulação categorial, e serve de base à teoria X-barra. Segundo Lemle (1984), adotando esse princípio, leva-se em conta somente a estrutura da expressão, deixando-se o ônus da diversidade de funções que um sintagma de uma determinada categoria pode exercer para um componente de regras interpretativas.

Outro lado da mesma questão, segundo Lemle (1984), é a descrição dada às chamadas locuções prepositivas ${ }^{10}$ : expressões formadas de advérbios seguidos de preposições (abaixo

\footnotetext{
${ }^{10}$ Detivemos-nos no tratamento de estruturas como 'dentro de', 'abaixo de'. No entanto, a autora também discute estruturas em que uma preposição é seguida de SP (Lemle, 1984:161):

i) Para com os colegas.
} 
de, dentro de). Adotando o princípio de rotulação categorial e prevendo que um advérbio pode ter complementos, a autora afirma que, na tradição gramatical, em dados como (3a), temos um advérbio e, em dados como (3b), temos um sintagma adverbial, explicitados pela estrutura em (4) (Lemle, 1984:131):

(3) a. Dentro/ depois/ abaixo

b. Dentro da caixa/ depois da festa/ abaixo do título

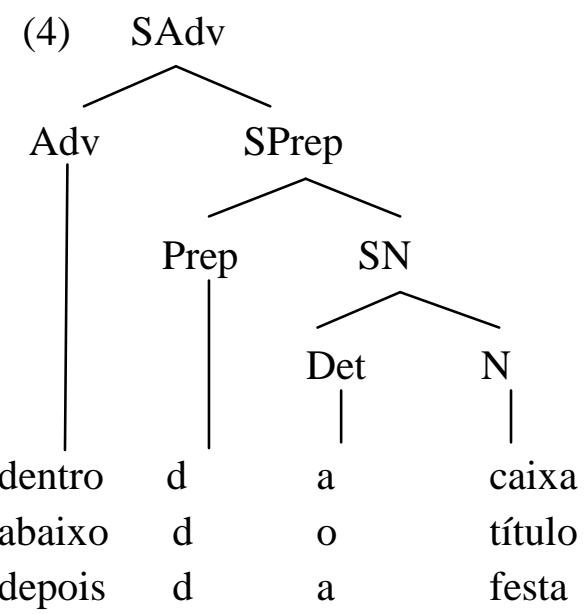

No entanto, para que a análise de (3a, b) seja válida, é preciso considerar que, nos casos em que ocorre a contração entre a preposição e o nome do $\mathrm{SN}^{11}$, como em (5), poderíamos ter uma mudança de classe lexical, ou seja, é possível considerar a adverbialização de sintagmas preposicionais.

(5) Apesar de/ abaixo de/ acima de/ defronte de

ii) De sobre a mesa.

iii) Por entre as árvores.

A autora demonstra que o SP complemento de preposição é, por sua vez, constituído de preposição mais sintagma preposicional (Lemle, 1984: 161-162):

iv) Para fora de casa

v) De dentro da comunidade

vi) Desde antes da festa

vii) Por debaixo da mesa

E aponta que a interação de SPs é gramaticalmente ilimitada (Lemle, 1984: 163):

viii)Depois de depois de depois de amanhã

Lemle (1984) sugere que o processo diacrônico no qual novas preposições formaram-se por aglutinação de duas preposições que eram separadas (de-ex-de >desde; de-entre > dentre; per-ante > perante; a-de-ante > adiante) poderia ser explicado como consequência de uma pressão para minimizar o excesso de interação entre SPs.

${ }^{11}$ Neste capítulo, adotaremos as siglas em português, utilizadas pelas autoras (SN, SV, SAdv, SP, SA). 
Assim, para esclarecer as fronteiras entre advérbio e preposição, a autora coloca a necessidade de rejeitar o princípio da rotulação funcional e reafirmar a rotulação categorial dos sintagmas. Para aceitar a análises em (3) e (5), a autora ressalta a necessidade de reconhecer o fato de que, na gramática do português, é possível adverbializar sintagmas preposicionais devido a um processo que reduz preposições a prefixos.

Para dados como os que constam em (6), Lemle (1984) traz uma análise pouco conservadora da categoria advérbio. Partindo do pressuposto de que preposições podem ser transitivas e intransitivas, Lemle (1984) postula um tratamento uniforme para esses elementos:

(6) antes, depois, abaixo, acima, dentro, fora

Tais itens são classificados nas gramáticas tradicionais como advérbios, quando ocorrem em configuração intransitiva, como em (7a), ou como locuções prepositivas, quando ocorrem em configurações transitivas, como em (7b):

(7) a. João dormiu fora.

b. João dormiu fora de casa.

A autora observa que, além de captar a semelhança na distribuição sintática, o tratamento desses itens como preposição tem o mérito de "revelar a semelhança existente entre a classe das preposições e as demais classes de palavras, pois só com esse tratamento ganhamos a generalização de que a transitividade ou intransitividade é uma propriedade de subcategorização estrita não apenas dos verbos, mas também dos nomes, adjetivos e preposições (p. 161).” Embora reconheça que palavras como

(8) aqui, ali, ontem, amanhã, cedo, bem, mal, cuidadosamente

da suposta classe dos advérbios, sejam exclusivamente intransitivas, Lemle (1984) apoia-se na semelhança semântica e na distribuição sintática para reafirmar a hipótese de que os advérbios são uma subclasse das preposições.

Observando dados sincrônicos, a autora observa que SPs e advérbios são semelhantes semanticamente e podem ocupar funções sintáticas idênticas. Vejamos os dados abaixo, que 
ilustram os seguintes contextos: a) verbos modificados por advérbios em contraste com verbos modificados por SPs sinônimos (9); b) adjetivos modificados por advérbios em contraste com adjetivos modificados por SPs sinônimos (10); advérbio modificando SPs em contraste com SPs modificando SPs (11); e nomes que permitem a modificação por advérbios e por SPs equivalentes (12).

(9) a. Trabalhe atentamente.

b. Trabalhe com atenção.

(10) a. Cuidadoso demais.

b. Cuidadoso em demasia.

(11) a. Excessivamente com cuidado.

b. Com cuidado em excesso.

(12) a. A nossa revolta hoje.

b. A nossa revolta neste dia.

Testando os dados acima, Lemle (1984) chega à conclusão de que todos os contextos que admitem modificação por advérbios também admitem modificação por PPs. Assim, para a autora, a classe mais abrangente é a das preposições, e os advérbios constituem uma subclasse das preposições. Argumentos diacrônicos também sustentam essa afirmação. Lemle (1984) afirma que, na história da língua, o processo de aglutinação lexical, no qual há uma sequência de preposição mais nome ou preposição mais advérbio, contou como uma única unidade léxica, dada como advérbio. Mas, essas aglutinações tiveram lugar porque preservaram a estrutura. Assim, uma preposição intransitiva (que, para a autora, é o mesmo que advérbio) equivale, em termos de categoria, a uma preposição seguida de nome ou de outra preposição intransitiva (p. 170):

(13) a. ad-maniana $>$ manhã

b. ad-bassiu > abaixo

c. ad-nocte $>$ aõnte $>$ ontem

d. de-repente $>$ de repente

e. $a d$-sic $>$ assim 
Apoiando-se, sincronicamente, nas propriedades distribucionais e na semelhança semântica entre advérbios e preposições e, diacronicamente, no processo de aglutinação que, apesar de alterar as fronteiras lexicais, não altera a categoria do nó superior, preservando o rótulo lexical (SP), Lemle (1984) justifica a inclusão dos chamados advérbios como um subconjunto da classe das preposições.

Bomfim (1988) faz uma análise da proposta de Lemle (1984). A autora observa que os estudos têm enfatizado que “(...) uma das características dos advérbios e das locuções adverbiais é conterem explícita ou implicitamente uma preposição” (p. 13). Observa ainda que há, porém, casos em que é impossível admitir-se uma preposição implícita, como no contraste em (14) - exemplos da autora (pp. 12-13):

(14) a. Ele procedeu hipocritamente (=com hipocrisia)

b. Condeno sua atitude hipocritamente amável.

c. *Condeno sua atitude amável com hipocrisia.

Tais dados questionam estudos como o de Lemle (1984) que, como vimos, desenvolve uma argumentação no sentido de propor que os advérbios são uma subclasse das preposições. Bomfim (1988) discorda que itens como perto, atrás, fora, dentro, adiante sejam tratados como preposições. Para Bomfim, esses itens em estruturas similares àquelas propostas por Lemle, são sempre relativas a um ponto de referência explícito ou não, daí a possibilidade de utilizá-los com ou sem preposição:

(15) a. Deixei o carro perto.

b. As crianças vinham atrás e os adultos, adiante.

(16) a. Deixei o lixo perto da escada.

b. As crianças vinham atrás das mães e, adiante do palanque, os professores aguardavam.

Bomfim (1988) concorda com Lemle (1984) em que se pode considerar um espaço vazio, que seria ocupado pela preposição e o termo subordinado, como em (17):

(17) Ele preferiu falar depois. 
No entanto, não concorda que depois, perto, fora etc. sejam sintagmas preposicionais, apoiando-se nos seguintes argumentos: primeiramente, esses elementos podem ser intensificados, enquanto os sintagmas preposicionais não podem (p. 44):

(18) a. Só vim conhecê-la bem depois.

b. Fomos encontrá-lo mais adiante.

c. Pude notar que o som vinha de muito perto.

(19) a. *Vim muito de casa, agora.

b. *Saí muito sem casaco apesar do frio.

c. *Comprei papel muito para embrulhar o presente.

Em dados como (20a), a intensificação recai sobre o verbo, não sobre a preposição ou sobre o SP; em (20b), a intensificação recai sobre o advérbio e não sobre a locução (p.45):

(20) a. Saí muito com ela no ano passado.

b. Saí bem depois da Ana.

Em segundo lugar, as preposições estabelecem uma relação entre dois termos, assim, os elementos relacionados não podem ter a mesma função, o que a autora ilustra com a estruturação do sintagma nominal (p.45):

(21) O sino de ouro

Em (21), a preposição de subordina ouro a sino. Com exceção das próprias preposições e conjunções, praticamente todas as classes aparecem como antecedentes de preposição. Dessa maneira, para a Bomfim (1988), não seria adequado considerarmos os advérbios como preposições, pois os advérbios em questão formariam um conjunto representativo de exceções, não justificando afirmar "que a preposição pode subordinar um termo a outra preposição" (p.46).

Em terceiro lugar, as preposições precisam do pronome pessoal regido em sua forma tônica (22a, b); enquanto advérbios como perto/longe, antes/depois, adiante/atrás etc. (23a, b) possuem seu ponto de referência regido por preposição e é esta que exige a forma tônica do pronome (p.46): 
(22) a. Patrícia, Ana e Cecília têm saudades de mim.

b. Pedro e Leonardo conversaram comigo.

(23) a. Patrícia sentou-se perto de mim.

b. Ana e Cecília chegaram antes de mim.

Em quarto lugar, Bomfim (1988) afirma que o fato de advérbios e SPs poderem ser usados nos mesmos contextos não implica dizer que advérbio é preposição, pois é preciso distinguir classe de função. Nos dados abaixo, a autora admite a mesma leitura, mas bem (24b) modifica todo o sintagma, não apenas a preposição em (p.46):

(24) a. Eles conversaram bem pacificamente.

b. Eles conversaram bem em paz.

Por último, no que se refere ao argumento diacrônico, Bomfim (1988) lembra que, além das estruturas que deram origem à aglutinação lexical (preposição + substantivo e preposição + advérbio) que resultaram em advérbios, em latim, alguns advérbios, como foras ou foris ("do lado de fora") tomaram valor transitivo, passando à classe das preposições. Assim, muitas preposições latinas originárias de advérbios vieram para o português. Resumindo, o trânsito acontece de uma classe para a outra nos dois sentidos. Dessa maneira, Bomfim (1988) conclui que preposições e advérbios constituem classes distintas, apesar de seus pontos de contato.

Lobato (1989) retoma o debate entre Lemle (1984) e Bomfim (1988), fazendo referência à distinção entre verdadeira preposição e preposição marcadora de Caso ${ }^{12}$, para

\footnotetext{
${ }^{12}$ Nesta versão da teoria gerativa, postula-se que marcação de Caso nos DPs é um fenômeno universal. A marcação de Caso é um fenômeno essencialmente sintático, assim, os DPs recebem um Caso abstrato na sintaxe que, dependendo da língua, pode ou não receber manifestação morfológica. No que diz respeito às categorias lexicais nome e adjetivo possuem o traço [+N], enquanto verbos e preposições possuem traço [-N]. O traço [-N] é a propriedade responsável pela atribuição de Caso, logo, Chomsky $(1981 ; 1986)$ observa que nomes e adjetivos não são capazes de realizar superficialmente o Caso que atribuem, dessa maneira, o português recorre à estratégia de introduzir a preposição semanticamente vazia de para marcar a realização de Caso; enquanto verbos e preposições podem realizar superficialmente o Caso que atribuem, não sendo necessária a presença de uma preposição marcadora de Caso. Vejamos os dados abaixo (Raposo, 1992: 364):

i) *A [NP destruição [o brinquedo]].
}

O DP o brinquedo não recebe Caso de NP e é excluído pelo Filtro de Caso, que prevê a agramaticalidade de uma sentença em que haja um DP com matriz fonológica e sem Caso. Assim, para que estruturas como em (i) se 
demonstrar que itens como adiante, atrás, dentro, depois etc. são advérbios, não são preposições. As verdadeiras preposições desempenham um papel semântico próprio e os sintagmas que as seguem são seus reais complementos, consequentemente, delas recebem Caso:

(25) a. Veio sem dinheiro.

b. Viajou com os amigos.

c. Luta contra todos.

Diferentemente, o elemento de, que introduz complementos de adjetivos e nomes, não tem papel semântico próprio e não tem o sintagma seguinte como seu verdadeiro complemento, exercendo, assim, a função de marcador do Caso atribuído ao SN introduzido:

(26) a. O seu desejo de sucesso.

b. Desejoso de sucesso.

Lobato (1989) afirma que quando temos um complemento manifesto para elementos como adiante, além, atrás, dentro, fora, longe, perto, antes, depois, etc., ele é sempre precedido da preposição "de", que não tem o sintagma seguinte como seu verdadeiro complemento, logo trata-se de um marcador de Caso e não de uma verdadeira preposição.

Seguindo essa análise, que distingue verdadeiras preposições e preposições marcadoras de Caso, a autora demonstra que nomes e adjetivos não são capazes de realizar superficialmente o Caso que atribuem, por isso a necessidade de ocorrência do de para marcar a realização do Caso; enquanto verbos e preposições podem realizar superficialmente o Caso que atribuem, não sendo necessária a presença de uma preposição marcadora de Caso. Com essa análise, a autora conclui que, se elementos como perto fossem preposições, não permitiriam a presença do elemento de antes de seu complemento. Como esses elementos exigem a presença da preposição marcadora de Caso para introduzir o complemento, perto pertence a uma categoria sem capacidade para realizar superficialmente Casos atribuídos, o

tornem gramaticais, no português, a preposição de, semanticamente vazia, é introduzida e vai reger e realizar o Caso atribuído inerentemente pelo núcleo nominal ao DP o brinquedo:

ii) A [NP destruição [de [o brinquedo]]]. 
que confirma que constituem uma categoria independente, a dos advérbios, comparável aos nomes e adjetivos no que se refere à incapacidade de realizar Caso.

Assim, para dados como (27), a autora concorda com Bomfim (1988), e seguindo o princípio gramatical de que todo sintagma é projeção de seu núcleo, afirma que temos um sintagma adverbial, pois perto é o núcleo:
(27) a. Perto
b. Perto de casa.

Segundo Lobato (1989), deixando o elemento de de ser tratado como preposição, estruturas como (27b) não conteriam um SP encaixado, mas seriam a projeção de um advérbio que possui um SN complemento, no qual o elemento de apareceria pela necessidade do SN complemento receber Caso. Assim, tanto perto quanto perto de casa seriam tratados como sintagmas adverbiais e não como SPs. Lobato (1989) concorda ainda com Bomfim (1988) no que diz respeito ao fato de que em elementos como perto há um ponto de referência implícito, ocorrendo o SN como uma categoria vazia. Neste caso, para as autoras, não há a necessidade de tratá-los como tendo dois usos, conforme propõe Lemle (1984): um transitivo e outro intransitivo. Para Bomfim e Lobato, simplesmente, o complemento desses advérbios pode vir explícitos ou implícitos (como categoria vazia).

Quanto ao argumento de Bomfim (1988) de que elementos como dentro, fora, etc., se distinguem das preposições por aceitarem intensificadores, Lobato (1989) afirma que não há uma diferença tão notável entre advérbios e preposições por esse motivo. O fato, para Lobato, é que as preposições não aceitam a incidência de intensificador apenas sobre elas, pois as preposições, salvo raras exceções como vote contra, necessitam de seus complementos a fim de se ter o SP, enquanto temos, para advérbios que possuem complementos, a possibilidade de serem manifestos ou não. Lobato também afirma que, para advérbios que exigem a manifestação de seus complementos, como relativamente, referentemente, etc., não se pode ter a incidência de intensificador e a ausência do consequente (p.109):

(28) *Ela falou [bem relativamente] ao assunto do nosso trabalho.

Dessa maneira, um advérbio sem complemento manifesto pode formar um SAdv, mas um SP não pode ser formado apenas pela preposição, necessitando de seu complemento manifesto, por isso não é possível ocorrer uma sequência com intensificador da preposição. 
Além disso, a autora ressalta que, os elementos em questão não são preposições, pois admitem a não manifestação lexical de seu complemento, as preposições não a admitem.

Lobato (1989) traz também o argumento da convenção pied-piping para a análise de que advérbios não são preposições. A autora lembra que, em português, ao contrário do inglês, é necessária a aplicação da convenção pied-piping em que, ao se deslocar um sintagma que integre um PP, a preposição precisa se deslocar junto (p.110):

(29) a. Para onde você viajou?

b. *Onde você viajou para?

Com os advérbios em questão, o deslocamento junto com seus complementos não é necessário (p.110):

(30) a. Ele passou adiante de quem?

b. De quem ele passou adiante?

Segundo a autora, em português, uma preposição não pode ficar órfã, mas os elementos em questão podem, assim, tais elementos são advérbios, não são preposições.

Enfim, a proposta de Lobato (1989) retém da proposta de Lemle (1984) as vantagens de se dar um tratamento unificado aos elementos denominados pela tradição ora advérbios, ora preposições; mas, em Lobato, temos advérbios em qualquer emprego desses elementos. A generalização intercategorial relacionada à complementação proposta por Lemle também é retida no estudo de Lobato, no entanto, se refere a advérbios e não a preposições. Da análise de Bomfim (1988), Lobato retém a classificação como advérbios, mas não mantém o tratamento de estruturas como dentro de como locuções prepositivas ou SPs.

Lobato (1995) faz novamente uma retomada dos estudos de Lemle (1984) e Bomfim (1988) no que se refere à discussão que distingue preposição e advérbios. Nesta discussão, a autora continua defendendo a hipótese de que itens como adiante são, efetivamente, advérbios; mas, contrariamente à hipótese de seu trabalho de 1989, a autora chega à conclusão de que itens como adiante de mim são SPs, concordando integralmente com a proposta de Bomfim (1988).

Lobato (1995) considera que os advérbios permitem dois tipos de estruturação sintática (semelhantes à estruturação interna dos adjetivos): 1) podem ocorrer à esquerda do elemento que modificam (na ordem da regência da língua), projetando um SAdv com 
estrutura de complementação, da qual são núcleos (31a); e 2) podem ocorrer à direita do elemento que modificam (ordem inversa da regência da língua), projetando uma estrutura de adjunção (31b).

(31) a.

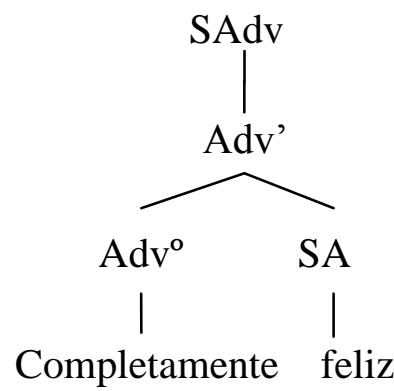

b.

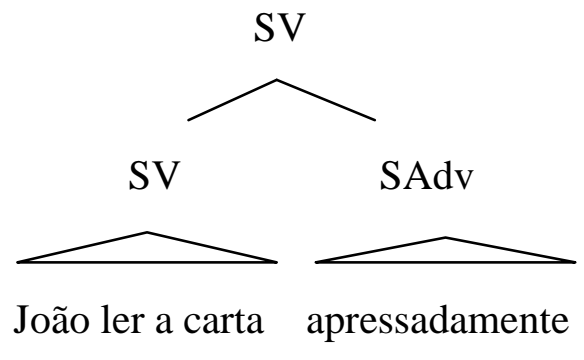

Assim, para itens como adiante, a autora propõe a estrutura em (32), pois há uma categoria vazia como complemento e, por não haver realização fonética do complemento, não há projeção de uma preposição:

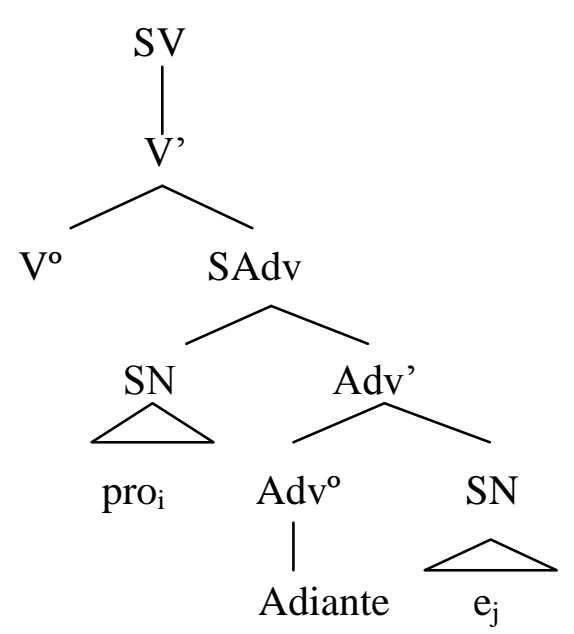

Para itens como adiante de mim, a autora propõe a estrutura em (33) e, considerando que as preposições projetam uma configuração de pequena oração, o SV do exemplo abaixo conterá duas configurações desse tipo: 
(33)

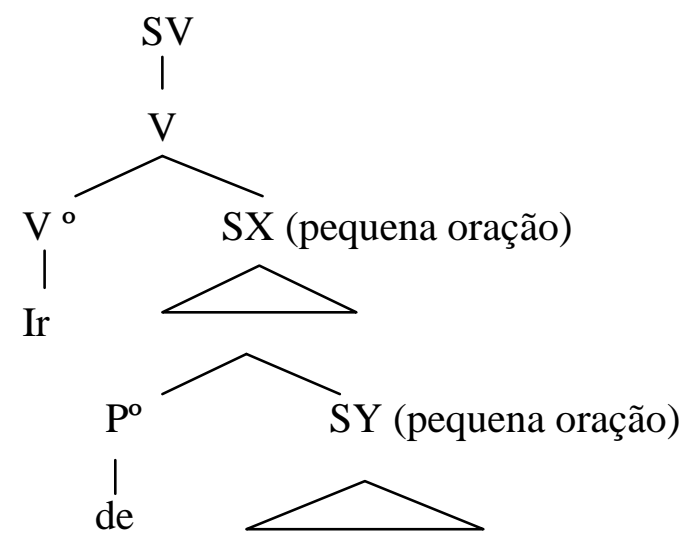

Em (34), a estrutura de adjunção do complemento de de precisa ter como argumentos os itens adiante e mim, que são antecedente e consequente de $d e$. Assim, o nódulo que a sequência de adiante mim projeta é um SP. O SP é o segundo constituinte da pequena oração complemento de $\mathrm{V}$, pois o primeiro argumento é pro:

(34)

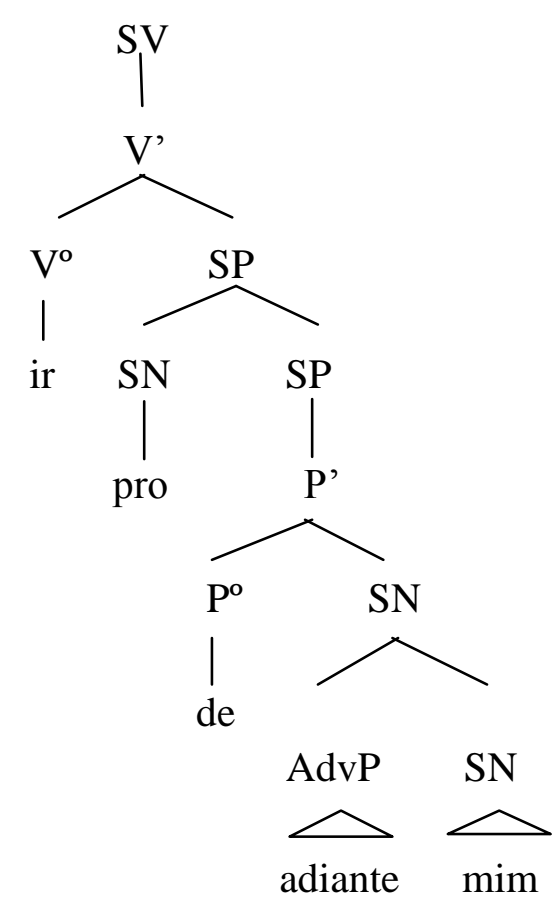

A autora ressalta que tanto para a derivação em (32) quanto para a derivação em (34) há movimento de constituintes. Em (32) há deslocamento do SN no Spec de SAdv para o Spec de SV (35); e em (34), há deslocamento do constituinte à esquerda, no interior de cada estrutura de adjunção para a posição imediatamente mais alta de Spec (36): 
(35)

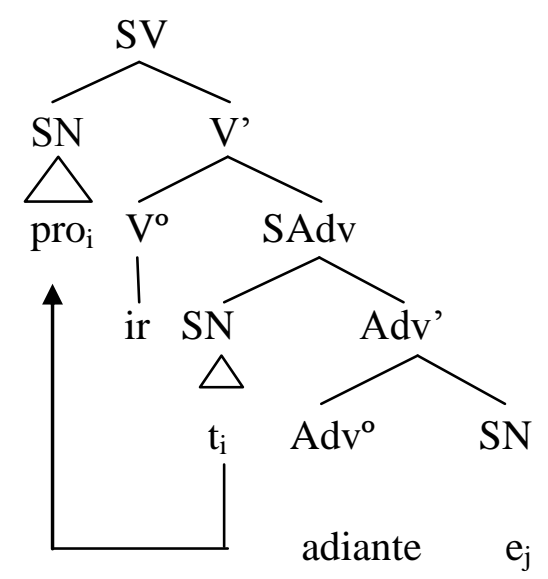

(36)

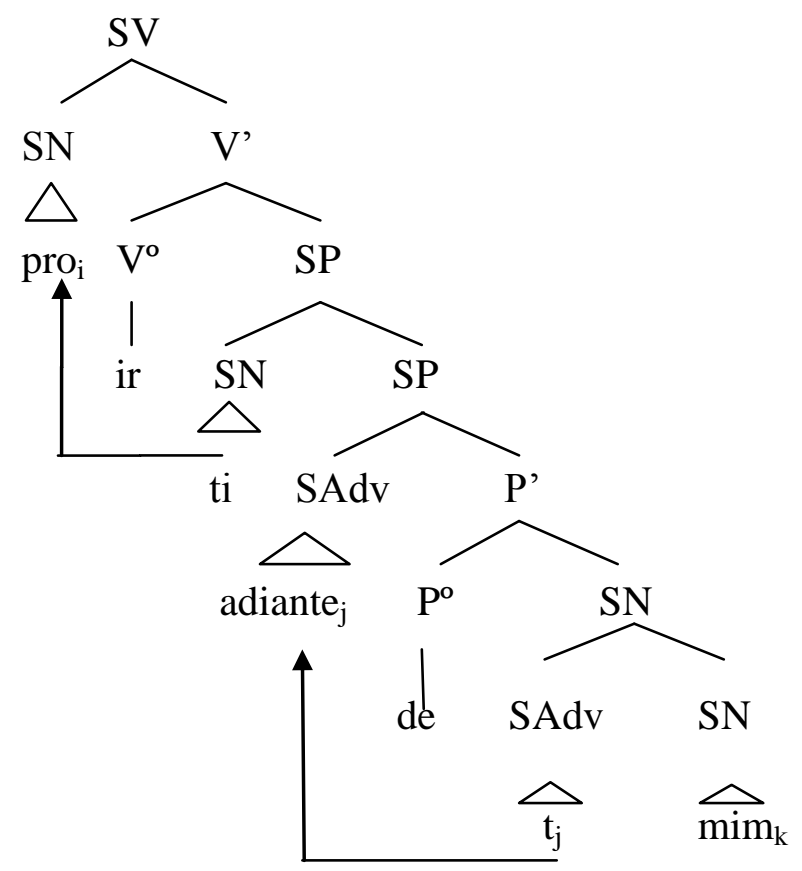

Dessa maneira, Lobato (1995) demonstra que itens como adiante podem ocorrer em estruturas de adjunção ou de complementação, a depender do elemento com o qual irá combinar-se. Se o elemento for uma categoria manifesta, vai exigir Caso. Como adiante não atribui Caso, faz-se necessária a presença do marcador de Caso de, assim, será projetado um SP e, no interior desse SP, adiante será um dos constituintes da configuração de adjunção. Mas, se adiante se combina com uma categoria vazia será capaz de projetar um complemento sem a presença da preposição. Assim, na análise da autora, palavras como adiante são advérbios, porque de é o núcleo do sintagma que contém o SAdv adiante na configuração de pequena oração. Nesse sentido, confirma-se a posição tradicional defendida por Bomfim (1988) de que adiante é advérbio e adiante de é uma locução prepositiva. 
Consideramos que a análise de Lobato (1995) se sustenta em termos teóricos e conceituais, ao garantir a uniformidade no tratamento dos itens do tipo adiante, perto, independentemente de estarem em configurações transitivas e intransitivas, confirmando-se seu estatuto categorial de advérbio, em oposição à categoria preposição. Essa distinção mostra-se desejável no tratamento da produtividade das locuções prepositivas, por um lado, e das propriedades denotativas do advérbio, por outro, confirmando-se sua autonomia categorial.

$\mathrm{Na}$ próxima seção, continuaremos a discussão quanto ao estatuto categorial dos advérbios, e à hipótese de que tal categoria compreende subclasses, retomando o estudo de Bomfim (1988) no que se refere a advérbios com interpretação locativa e temporal. A discussão se torna relevante para este trabalho na medida em que a autora atribui propriedades de pronomes a advérbios locativos e temporais.

\subsection{Advérbios e pronomes: Bomfim (1988)}

Conforme mencionado, o estudo de Bomfim (1988) também tem como questionamento inicial o tratamento uniforme encontrado nos compêndios gramaticais em relação aos elementos que compõem a classe dos advérbios. Nesse sentido, a autora propõe-se demonstrar que tais elementos apresentam propriedades distintas do ponto de vista semântico e sintático. Um aspecto relevante dessa discussão é o estatuto categorial desses elementos. Por isso, retomamos aqui o estudo de Bomfim (1988), mas agora, para analisar as propriedades de advérbios de tempo e lugar ${ }^{13}$. A autora ressalta que, segundo a tradição, advérbios de tempo devem responder à pergunta: quando?; e advérbios do tipo ontem, hoje e amanhã são incluídos no mesmo grupo de advérbios como cedo e tarde. No entanto, é necessário separálos, uma vez que demonstram propriedades diferentes. De fato, uma característica que os distingue diz respeito ao fato de que cedo e tarde não respondem à pergunta quando?. Tal restrição se explica pelo fato de que cedo e tarde se ligam ao processo verbal. A autora acrescenta:

\footnotetext{
${ }^{13}$ Discutiremos mais adiante a proposta de Cinque (1999), que demonstra que advérbios com interpretação locativa e temporal (ib, id) podem realizar-se como PPs (ia, c), o que está de acordo com a discussão de Bomfim (1988), em que a semelhança entre preposições e advérbios não exclui que sejam considerados classes distintas.
}

(i)a. Ela está na Universidade.

b. Ela está aqui.

c. Ela chegou neste momento.

d. Ela chegou agora. 
(...) não podemos, entretanto, dizer que indique posição no tempo em relação ao momento em que se fala, nem tampouco a um fenômeno focalizado, a não ser que esse seja entendido como um ponto neutro convencional, impreciso, subjetivo, com respeito ao qual houvesse uma anterioridade (cedo) e uma posteridade (tarde) (BOMFIM: 1988, pp. 27-28).

Bomfim (op. cit.) ainda observa que cedo, tarde, por um lado, e ontem, hoje, amanhã, por outro, também se distinguem porque cedo e tarde podem co-ocorrer com outros advérbios de tempo (37a), podem ser intensificados (37b) e podem ser antecipados (37c):

(37) a. Ele chegará amanhã cedo.

b. Ele chegará muito cedo.

c. Ele chegará cedo amanhã.

Além disso, tais elementos podem ser intensificados e antecipados, mesmo quando ocorrem com outros advérbios de tempo:

(38) a. Ele chegará amanhã muito cedo.

b. Ele chegará muito cedo amanhã.

Por sua vez, advérbios como ontem, hoje e amanhã é que possuem uma referência precisa e referem-se a todo o enunciado, o que, segundo Bomfim (op. cit.), pode contribuir para que não haja alteração de sentido na mudança de posição:

(39) a. Marcelo chegará do Maranhão amanhã.

b. Amanhã Marcelo chegará do Maranhão.

c. Marcelo amanhã chegará do Maranhão.

d. Marcelo chegará amanhã do Maranhão.

Por denotarem um ponto de referência preciso, não são passíveis de intensificação, distinguindo-se, portanto, dos advérbios do primeiro grupo (cedo e tarde):

(40) a. *Marcelo chegará do Maranhão muito amanhã.

b. *Marcelo chegou cansado muito ontem.

c. *Marcelo está cansado muito hoje. 
Segundo Bomfim (1988), os advérbios do tipo ontem, hoje e amanhã compartilham algumas características dos pronomes: são dêiticos, substituem uma expressão nominal e podem exercer a função de sujeito da oração ${ }^{14}$. É o que está ilustrado nos exemplos abaixo: ${ }^{15}$

(41) a. Hoje e amanhã são dias de festa.

b. Ontem foi um dia péssimo.

c. Amanhã será outro dia.

(Bomfim: 1988, p. 31)

Constatamos que 'cedo' também pode ocupar posição de sujeito, no entanto há restrições semânticas, pois tal distribuição só será possível quando o advérbio ‘cedo' ocorrer em um predicado que denote um ponto específico em uma escala que o opõe a outro ponto (42a), sendo a construção agramatical quando o predicado não apresenta essa denotação (42b):

(42) a. Cedo é o momento ideal do dia para viajar.

b. *Cedo é dia de festa.

Os advérbios de lugar do tipo aqui, aí, lá, entre outros, segundo Bomfim (1988), também compartilham com os pronomes as mesmas características citadas em relação aos advérbios de tempo, entre elas, a de poderem exercer a função de sujeito:

(43) a. Aqui é o melhor lugar do mundo.

b. Lá continua [sendo] um paraíso.

Para Bomfim (1988), palavras como ontem, hoje e amanhã, aqui, aí e lá estariam mais bem classificadas como pronomes. No entanto, a autora reconhece que, se tais palavras compartilham certas características com a classe dos pronomes, também compartilham características com os advérbios, como, por exemplo, expressar circunstância, conforme

\footnotetext{
${ }^{14}$ Trataremos mais detalhadamente de advérbios locativos na posição de sujeito no capítulo 4.

${ }^{15}$ Conforme observado por A. Nevins (p. c.), evidência adicional para o caráter pronominal de advérbios é observada em línguas como o italiano e o francês, em que as formas $c i$ e $y$, respectivamente, ocorrem como categorias pronominais e anafóricas.
} 
propõe a definição tradicional. Assim, o que percebemos é que é necessário descrever suas propriedades para definir se há uma subclasse com comportamento sintático-semântico comparável ao dos pronomes, mantendo-se, porém, vinculados à categoria dos advérbios.

Ilari et al. (1989) também ressaltam que os advérbios dêiticos possuem propriedades diferentes das demais palavras que compõem o grupo dos advérbios. Os autores apontam que advérbios do tipo dêiticos podem ocorrer como determinativos, como em (44a), e em posição argumental, como em $(44 \mathrm{~b}, \mathrm{c})$ :

(44) a. Mas a cadeia de supermercados aqui é do Recife.

b. Hoje tem sistema financeiro de habitação.

c. Eu gosto demais de lá e gostaria de morar, então eu estive vendo

preços de aluguel. (Ilari et al: 1989, p,59)

Para os autores, "a elipse de lá depois de morar reforça a análise de lá como argumental depois de gosto de" (ILARI et al: 1989, p.59).

Como será demonstrado adiante, algumas propriedades citadas podem ser discutidas em termos da tipologia proposta por Cinque (1999), particularmente no que se refere à distinção entre advérbios altos e baixos e à possibilidade de ocorrerem em posição argumental. Nossa hipótese de trabalho é a de que os advérbios dêiticos, ao ocorrerem como modificadores sentenciais, manifestam propriedades de núcleos funcionais, podendo também assumir propriedades argumentais, por suas propriedades referenciais. Essa questão será retomada adiante. ${ }^{16}$

Na próxima seção, apresentamos estudo de Lobato (2005/2008), em que a autora investiga construções em que o advérbio em -mente alterna com uma forma reduzida, em posição idêntica, o que leva ao questionamento quanto ao seu estatuto categorial - como advérbio homófono ao adjetivo correspondente ao advérbio em -mente, como resultado de conversão morfológica, ou ainda como uma categoria - considerando ainda os casos em que a alternância não ocorre. Essa discussão coloca o problema do estatuto do advérbio na relação com o adjetivo, mostrando o significado da oposição entre essas categorias, mostrando-se significativa para o nosso trabalho na medida em que demonstra de maneira profícua o significado da distinção categorial para a teoria gramatical.

\footnotetext{
${ }^{16} \mathrm{Na}$ análise de Pilati (2006), advérbios temporais/ locativos, como 'hoje', 'ali', na posição de sujeito, licenciam a ordem VS, sugerindo uma configuração do tipo 'inversão locativa'. Em Pilati e Naves (2013), a existência dessa configuração no $\mathrm{PB}$ é vinculada à ocorrência de outros fenômenos de preenchimento da posição de sujeito por categorias não argumentais, encontradas nessa língua.
} 


\subsection{Advérbios e adjetivos: Lobato (2005/2008), Leung (2007), Foltran (2010)}

Lobato (2008: 219) ${ }^{17}$ contribui para a discussão acerca do estatuto dos advérbios, analisando "atributos tradicionalmente classificados como adjetivos em uso adverbial", como ilustram os dados abaixo:

(45) Elas andam torto.

(46) Maria fazia isso automático.

Para a autora, as construções acima possuem uma característica marcante: ocorrem sem o sufixo -mente, mas não concordam em gênero ou número com qualquer expressão nominal na sentença, distinguindo-se das construções com uso predicativo do atributo, em que não ocorre o sufixo -mente, mas há concordância:

(47) Elas andam tortas.

Comparando os dados abaixo, a autora ressalta que tanto em (48a) como em (48b), a predicação do atributo relaciona-se com uma projeção verbal (o andar é torto):

(48) a. Elas andam torto.

b. Elas andam tortamente.

Diferentemente, em (47), a predicação do atributo relaciona-se com o sintagma nominal (elas). Além da questão do escopo (sintagma nominal ou sintagma verbal), há também diferenças semânticas em alguns casos de alternância com ou sem o sufixo -mente, como nos dados abaixo, em que, no primeiro caso, entende-se a maneira como a banda toca e, no segundo, o intervalo de tempo em que a ação acontece:

(49) A banda toca regular.

(50) A banda toca regularmente.

\footnotetext{
${ }^{17}$ Lobato (2008) é a versão publicada da comunicação oral ao V Workshop 'Formal Linguistics at USP' em 2005.
} 
Outra questão relevante é que a alternância entre a forma em -mente e a forma reduzida nem sempre é possível, conforme indicado nos contrastes a seguir:

(51) Catarina falou claro.

(52) Catarina falou claramente.

(53) João fala alto.

(54) *João fala altamente.

A autora passa então a discutir algumas explicações encontradas em estudos prévios, particularmente para as ocorrências como as que aparecem em (45) e (46). Entre elas consta a hipótese de conversão morfológica, segundo a qual torto e automático passariam por um processo derivacional no léxico, entrando na estrutura sintática como advérbio; aponta que também já foi proposta uma zona fronteiriça entre advérbios e adjetivos, na qual estes portariam traços daqueles; e ainda a hipótese daqueles que defendem que são advérbios, havendo aí um caso de homofonia.

A hipótese de que torto e automático, nas orações acima, são tratados como adjetivo em uso adverbial justifica-se com o argumento de que não há concordância e com o de que as palavras destacadas possuem como escopo o verbo. Assim, conclui-se que tais palavras são genuinamente adjetivos que funcionam como advérbios em contextos como os ilustrados. Isso explica, inicialmente, o caráter invariável dessas palavras e o uso da vogal temática $-o$, típica de adjetivos. Contudo, segundo a autora, esta explicação apresenta alguns problemas:

Primeiro, impossibilita a distinção nítida entre as diferentes categorias gramaticais. Afinal, se existem duas categorias diferentes, cada uma definida por um tipo semântico específico que leva a uma dada distribuição sintática, é de se esperar que essa distinção se mantenha claramente em todos os usos dos membros de cada categoria. Em caso contrário se destruiria a generalidade da distinção. Em outras palavras, se esses itens são realmente adjetivos, não podem estar ocorrendo em contexto típico de advérbios e atípico de adjetivos têm que estar ocorrendo em contexto típico de adjetivos. Segundo, essa hipótese deixa sem explicação os fatos distribucionais. Terceiro, não explica a diferença semântica entre o uso do atributo com e sem o sufixo -mente nas sentenças com alternância (Lobato, 2008: 221).

No caso da hipótese de conversão morfológica, segundo Lobato (2008), torto e automático deixam de ser tratados como adjetivos em uso adverbial, pois trata-se de um processo morfológico, em que esses adjetivos assumem globalmente as propriedades dos 
advérbios. Nesse caso, eles passam a pertencer também à categoria gramatical 'advérbio', o que leva à hipótese de que são dois itens lexicais distintos, um adjetivo e outro advérbio. A autora considera que o problema seria aparentemente resolvido, pois os advérbios estariam sendo tratados como advérbios, e não como adjetivos em uso adverbial, já que a morfologia teria processado a conversão; e, consequentemente, resolveria a questão de serem invariáveis. Entretanto, a conversão morfológica não consegue explicar o uso da vogal temática - $o$ e não da vogal temática $-a$ - típica de advérbio-, além de sua distribuição e das diferenças semânticas entre o uso desses atributos com e sem o sufixo -mente.

Na hipótese de zona fronteiriça e de definição categorial por traços distintivos lexicais, a autora sintetiza a proposta de Perini (1989), em que as categorias gramaticais são identificadas por meio de marcação de traços distintivos. Os traços sugeridos pelo autor são (Perini, 1989 apud Lobato, 2008: 223):
A) A propriedade de ocorrer após um artigo, formando a sequência um sintagma nominal;
B) A propriedade de concordar em gênero com o núcleo do sintagma nominal a que pertence;
C) A propriedade de ocorrer após o verbo e sintagma nominal opcional, sem concordar, formando a sequência um sintagma verbal.

De acordo com os traços distintivos citados, uma palavra como cadeira seria marcada com traço A positivo (+), e traços B e C negativos (-); palavras como verde, que ocorrem como adjetivos e substantivos - mas não como advérbios- têm os traços A e B marcados positivamente (+), e o traço C marcado negativamente (-); e, palavras que podem ocorrer com o substantivo, como o adjetivo e o advérbio, como alto, por exemplo, os traços A, B e C seriam marcados positivamente (+). Todavia, Lobato (2008: 223) afirma que esta hipótese também não se sustenta, pois não explica as diferenças semânticas nem os padrões distribucionais - já que nem sempre ocorre a alternância entre as formas.

Na hipótese da homofonia, postula-se que há dois itens lexicais: torto, adjetivo; torto, advérbio; ou seja, constariam duas entradas lexicais. Há certa semelhança com a hipótese da conversão morfológica, mas, segundo Lobato (2008), a distinção está no fato de que, na conversão, há um processo morfológico, que transforma o adjetivo em advérbio e, na hipótese da homofonia, estes dois itens existem no léxico, independentemente de processo morfológico. Entretanto, para Lobato (2008), essa hipótese também é problemática, na medida em que não responde a questões como o fato de o advérbio, neste contexto, não 
apresentar a vogal temática - $a$, típica de advérbio; além de não explicar a possibilidade ou impossibilidade de alternância com ou sem o sufixo -mente.

Assim, Lobato (2008) propõe que os supostos adjetivos em uso adverbial são genuínos adjetivos em uso adjetival. As evidências favoráveis a essa hipótese são: os fatos distribucionais, as restrições à produtividade lexical das formações em -mente, as diferenças semânticas que as formas alternantes podem provocar, a vogal temática e a flexão de grau das formas sem -mente, o fato de serem formas invariáveis e seu uso em construção comparativa.

Assim, observa que atributos com e sem -mente podem ocorrer em três ambientes: ambiente 1, em que apenas são permitidas as formas sem -mente; ambiente 2, em que apenas as formas com - mente são permitidas; e ambiente 3, no qual ambas as formas são licenciadas. Nos casos de ocorrência no ambiente 1, a predicação recai sobre uma propriedade nominal não explícita; nos casos do ambiente 2, recai sobre a relação proposicional, que poderá ser toda a sentença ou uma relação intra-sentencial; e, no ambiente 3, o atributo pode recair sobre a relação proposicional ou sobre uma propriedade nominal não manifesta.

Em relação ao ambiente 1, Lobato (2008: 225) afirma que "a propriedade nominal é uma informação integrante da estrutura léxico-conceptual do verbo. Em outra parte, é a informação que leva à interpretação do ato verbal". Para ilustrar esta afirmação, utiliza, entre outros, o exemplo dos atributos barato/ caro.

(55) Vendi barato/ caro o apartamento.

(56) Comprei barato/ caro o apartamento.

(57) *Vendi baratamentel caramente o apartamento.

(58) *Comprei baratamente/caramente o apartamento.

Segundo Lobato (2008), os verbos vender e comprar implicam uma propriedade de preço/ valor, que é uma informação nominal. Assim, vender caro/ barato significa vender a um preço alto (caro) ou baixo (barato). E é sobre essa informação nominal que o atributo predica. A autora ressalta que não se trata da estrutura sintática da oração, mas da estrutura léxico-conceptual dos verbos.

Além de predicar sobre a propriedade nominal embutida no verbo, o atributo também pode predicar do ato que o verbo expressa. Observe:

(59) Paulo fuma escondido.

(60) *Paulo fuma escondidamente. 
É o ato de fumar que é escondido, isto é, o fumar é escondido ${ }^{18}$.

Neste ambiente, de uso categórico do atributo sem -mente, há também outra característica apontada por Lobato: sua posição é pós-verbal (antes ou depois do objeto), e isso decorre do fato de ser uma predicação sobre a propriedade do verbo:

(61) *Barato / caro vendi o apartamento.

(62) *Alto a professora fala.

Em ocorrências no ambiente 2, uso categórico do atributo com -mente, a autora postula dois grupos, de acordo com as posições possíveis na oração: o primeiro é composto por atributos de posição flexível, e o segundo, por atributos pós-verbais.

Os atributos de ordem flexível são aqueles cujo escopo da predicação é uma relação proposicional que inclui o sujeito e o tempo verbal. Precisamente, esses são os atributos sentenciais, os de tempo ou frequiência e os de maneira que predicam propriedade relativa à atitude mental, à postura, do indivíduo referido pelo sujeito. Os atributos de ordem estritamente pós-verbal são aqueles cujo escopo da predicação é o predicado, uma relação sintática que não inclui nem o sujeito nem o tempo verbal. Precisamente, esses são os atributos de grau e os de maneira que não predicam propriedade relativa ao indivíduo referido pelo sujeito (Lobato, 2008: 227).

Lobato (2008) considera três casos para atributos categóricos em -mente, com flexibilidade posicional: os atributos sentenciais, temporais e de modo. O primeiro caso é do tipo sentencial e compreende as seguintes subdivisões: atributos subjetivos, intersubjetivos, veritativos, modais e delimitadores. Atributos subjetivos podem expressar a opinião do falante ou do sujeito da oração mais alta em relação ao conteúdo proposicional:

(63) Infelizmente, choveu no fim de semana.

(64) *Infeliz, choveu no fim de semana.

Atributos intersubjetivos implicam que o falante manifesta-se para o interlocutor, demonstrando o que sabe sobre a veracidade da proposição:

\footnotetext{
${ }^{18}$ Embora não tenha sido exemplificado pela autora, consideramos válido comparar com: Maria fuma corrido/prolongado (=com baforadas seguidas/ longas).
} 
(65) Sinceramente, ele não serve para você.

(66) *Sincero, ele não serve para você.

Atributos veritativos expressam a posição do falante ou do sujeito da oração mais alta, para quem a proposição é verdadeira ou pode expressar concordância com a oração anterior:

(67) Certamente, passei na prova.

(68) *Certo, passei na prova.

Nos atributos modais, a relação proposicional no seu escopo é verdadeira, possível, necessária ou provável, e é expressa pelo falante ou pelo sujeito da oração mais alta:

(69) Possivelmente, serei convocada em novembro.

(70) *Possível, serei convocada em novembro.

Os atributos delimitadores expressam o ponto de vista com que o falante ou o sujeito da oração mais alta delimita o domínio em que a relação proposicional no seu escopo é verdadeira:

(71) Intelectualmente, Camila está bem.

(72) *Intelectual, Camila está bem.

Os atributos temporais, para a autora, constituem o segundo caso:

(73) Esporadicamente/ periodicamente/ geralmente, ministro aulas fora de Brasília.

(74) *Esporádico/ periódico/ geral, ministro aulas fora de Brasília.

Segundo ela, existem, ainda, casos em que pode haver focalização de constituinte. Assim, na posição pré-verbal, o atributo mantém sua predicação sentencial, mas em posição pós-verbal seu escopo é, a primeira vista, o primeiro constituinte mais próximo à direita:

(75) Provavelmente a professora leu esse livro. 
(76) A professora provavelmente leu esse livro.

(77) A professora leu provavelmente esse livro.

Neste último exemplo (77), segundo Lobato (2008), a relação se dá entre provavelmente esse livro, por um lado, e a professora leu, por outro. Os atributos de modo constituem, para a autora, o terceiro caso:

(78) Pedro resistiu à doença heroicamente.

(79) *Pedro resistiu à doença heróico.

Lobato aponta dois casos em que atributos categóricos em -mente acontecem apenas em posição pós-verbal. O primeiro é o de atributos que expressam grau de completude do evento, eles não predicam sobre o sujeito, apenas sobre o verbo e seus eventuais complementos e, por isso, são barrados na posição pré-verbal:

(80) Decorei a sala completamente.

(81) *Decorei a sala completo.

(82) Decorei, completamente, a sala.

(83) *Decorei, completo, a sala.

(84) *Completamente decorei a sala.

(85) *Completo decorei a sala.

O segundo caso é constituído por atributos de modo que não predicam propriedade do indivíduo referido pelo sujeito. Seu escopo, assim como no caso anterior, é o predicado, como em (86). Quando é possível a ocorrência pré-verbal, deixa-se de ter escopo sobre o predicado e passa-se a ter escopo sentencial, como em (87):

(86) a. Felipe vive arriscadamente.

b. *Felipe vive arriscado.

(87) a. Produtivamente, essa Universidade vai bem.

b. *Produtivo, essa Universidade vai bem. 
Outro uso categórico de atributos em -mente ocorre quando se trata de um intensificador, em que há predicação sobre o sintagma adjetivo:

(88) Este aluno é altamente qualificado para a vida acadêmica.

(89) *Este aluno é alto qualificado para a vida acadêmica.

Dessa análise com os dois grupos examinados, com e sem flexibilidade posicional, Lobato conclui que há uso exclusivo com -mente, o que se deve ao fato de a predicação ser de relação proposicional.

Resumindo, há bloqueio da forma sem mente (a) quando o atributo predica de relação proposicional (sentença ou relação intra-sentencial, estando aí incluído o predicado) e (b) quando predica de adjetivo. Logo, o bloqueio ocorre em contextos típicos de advérbios e atípicos de adjetivos. Temos aí um argumento a favor de as formas sem mente serem adjetivos genuínos: a proibição ao uso da forma sem mente nesses contextos se deve ao fato de ela ter o estatuto de adjetivo e não haver, nesses contextos, predicação de propriedade nominal (Lobato, 2008: 230 -231).

Já no ambiente 3, podem ocorrer atributos com e sem -mente:

(90) Renata fala manso.

(91) Renata fala mansamente.

Contudo, Lobato (2008) ressalta que há diferença de escopo, pois em (90), o atributo predica do produto de falar: a voz, propriedade integrante da semântica do verbo; ao passo que, em (91), predica do processo verbal. Dessa maneira, pode-se concluir que a mansidão, em (91), manifesta-se não somente na fala, mas nos gestos, por exemplo, que fazem parte do processo. Este é, para a autora, mais um fator a favor da hipótese de que os atributos sem mente são genuínos adjetivos, já que predicam sobre a forma nominal.

O estudo da autora, sem dúvida, traz uma discussão consistente acerca dos problemas envolvidos nos casos de ocorrência alternada da forma em - mente e da forma reduzida, como torto-tortamente, exemplificado em (48a, b): o uso da vogal temática típica de adjetivos em palavras em contextos típicos de advérbios, a alternância entre as formas com e sem o sufixo -mente, bem como a mudança de sentido. Assim, a autora trabalha com a hipótese de que, 
nesses casos, tais palavras possuem um escopo sobre um elemento que não está realizado foneticamente na oração.

Leung (2007) ${ }^{19}$ concorda com a análise de Lobato de que, em dados como (90), manso predica sobre a informação nominal implícita (objeto cognato implícito), e chama essas construções de Pseudo-Adverbiais (PAs). A autora postula que os PAs sempre ocorrem adjacentes ao verbo, não apenas dentro do VP, mas também junto ao verbo (p.40):

(92) O Tor mordeu forte no meu braço.

(93) * O Tor mordeu meu braço forte..$^{20}$

Nos dados acima, (93) não é paráfrase de (92), pois o modificador incide sobre o objeto direto em (93), possibilitando a interpretação de que Tor mordeu o meu braço forte, e não o fraco. Para a autora, essa impossibilidade de se mover livremente pela sentença indica que os PAs possuem um escopo de modificação bastante restrito, o que demonstra que eles são diferentes dos advérbios.

Leung analisa os contextos de produtividade dos PAs, percebendo que essas construções ocorrem apenas com verbos que denotam atividade, que têm uma semântica de produção, ou seja, que licenciam um objeto cognato eventivo (p.50): abraçar um abraço apertado; beijar um beijo gostoso; chorar um choro amargo; rir uma risada engraçada; tossir uma tosse seca; pular um pulo alto; gritar um grito rouco, etc. Assim, não permitem objetos cognatos, nem modificadores PAs os verbos que não possuem um "produto" como (p.50) *aceitar uma aceitação, *afastar um afastamento demorado, *derrubar uma derrubada proposital, etc.:

(94) a. Maria aceitou a proposta *pronto/*gentil/*tímido.

b. Maria afastou a cadeira *delicado/*brusco/*calmo.

\footnotetext{
${ }^{19}$ Leung (2007) trabalha com a hipótese de Lobato (2008), no entanto, com uma versão do trabalho não publicada, apresentada no V Workshop 'Formal Linguistics at USP' em 2005.

${ }^{20}$ Foltran, em comunicação pessoal (por ocasião de defesa desta tese), questionou a agramaticalidade da sentença em (93), pois considera a leitura de modo permitida. Concordamos com Foltran, no entanto, consideramos que algum elemento prosódico é necessário para que haja essa leitura. Desse modo, a estratégia de adjacência não é explicativa. No entanto, a nosso ver, a proposta de Leung (2007) se sustenta uma vez que, em dados como (94), a autora confirma a agramaticalidade quando há um adjetivo modificando um objeto que não é cognato.
} 
Leung (2007) observa que, considerando que o PA tem como escopo o objeto cognato implícito, faz-se necessária a compatibilidade semântica entre o modificador e esse objeto (p.52):

(95) a. A Maria riu engraçado/esquisito/alto.

b. *A Maria riu *espontâneo/*escandaloso/*malicioso.

$\mathrm{Na}$ análise dos dados acima, a autora afirma que "uma risada pode ser, por si só, esquisita, engraçada ou alta. Porém, uma risada não pode ser, por si só, espontânea, escandalosa ou maliciosa" (p.52), já que em (95a) os modificadores não acarretam que Maria também seja engraçada ou esquisita, mas em (95b), não é possível que a risada seja maliciosa ou escandalosa sem que Maria também o tenha sido ${ }^{21}$.

Com essa análise, Leung (2007) adota a hipótese de Lobato (2005) refinando-a, pois, na proposta de Lobato, um modificador predica de uma propriedade nominal na estrutura léxico-conceptual do predicado. No entanto, alega que, em princípio, os verbos possuem uma informação que leva à interpretação de ato verbal, em termos de uma propriedade nominal, sendo assim, todos eles deveriam permitir, além do advérbio, a modificação por um adjetivo, mas, segundo a autora, não é isso o que acontece, visto que há dados em que a modificação por adjetivo não é possível, como ilustrado novamente abaixo. Nesse caso, segundo a Leung (2007), existiria incompatibilidade lexical/ semântica entre o modificador e a propriedade nominal, uma vez que o uso do modificador acarreta a orientação para o sujeito.

(96) Ela falou orgulhosamente/*orgulhoso dos filhos.

Um aspecto que parece relevante nessa discussão é que se, por um lado, o modificador na forma reduzida predica de um nominal (na estrutura léxico-conceptual do predicado), alternando modificadores em - mente que predicam do evento, por outro, é possível ainda que exista uma relação de posse inalienável entre esse nominal e o argumento na posição de sujeito, o que autoriza que haja alternância entre modificadores em -mente orientados para o

\footnotetext{
${ }^{21}$ Não consideramos os dados em (95) ruins. Mas, ainda assim, consideramos possível o argumento de Leung, tendo em vista a agramaticalidade dos dados em (94).
} 
sujeito e formas reduzidas, como em Maria falou raivoso comigo - essa questão será retomada.

Foltran (2010) questiona a proposta de Lobato, avaliando como vaga e nebulosa a propriedade nominal postulada, da qual os adjetivos predicariam, pois, para Foltran, não é trivial distinguir uma predicação sobre o ato verbal (um elemento nominal) ou sobre o processo verbal (um elemento verbal) em dados como (97), em que a propriedade escondido se aplicaria ao ato de comer:

(97) Ela come escondido.

Partindo da hipótese de Larson (1998), Foltran (2010) postula que adjetivos e advérbios podem predicar tanto de evento quanto de indivíduos e propõe redimensionar a categoria advérbio, em particular, os advérbios predicativos. Para explicar a alternância entre as formações com e sem -mente, a autora retoma a proposta de Geuder (2002). Segundo Geuder (2002 apud Foltran, 2010), a morfologia adverbial não tem papel principal na mudança de sentido entre predicados de indivíduos e predicados de eventos. O autor (apud Foltran, 2010) apoia-se em autores como Radford (1988) e Alexiadou (1997), que afirmam que o afixo adverbial faz parte do paradigma flexional do adjetivo em algumas línguas e no fato de que no alemão não há marcas que distinguem advérbios de modo e adjetivos, conforme dados abaixo:

(98) Hans verliess den Raum traurig.

H. left the room sad.

(99) John left sad / John left sadly. ～(Geuder, 2002: 38 apud Foltran, 2010: 165)

Considerando ainda que formas adverbiais não servem como input para novas derivações, que há um vazio semântico na morfologia adverbial e que com a adição de -mente não se podem formar novos lexemas, além de haver uma leitura regular do adjetivo, Geuder (2002 apud Foltran, 2010) propõe que a morfologia adverbial em -mente é mais próxima da flexão, sendo, portanto, desencadeada no contexto sintático e não no léxico. 
Partindo dos estudos de Kratzer (2005), Foltran (2010) delimita os contextos em que construções com adjetivos adverbiais ${ }^{22}$ podem ocorrer: com verbos intransitivos ou que se comportem como intransitivos:

(100) a. Ela falou duro.

b. A menina respondeu certo.

c. Ela leu gozado.

d. Ela dorme pesado.

(Foltran, 2010: 170)

A autora demonstra que, em alguns casos, pode haver um NP que funciona como argumento interno do verbo, mas, na presença do adjetivo adverbial, não pode ocupar a posição adjacente ao verbo ${ }^{23}$ :

(101) a. ? Ela leu esta carta bonito.

b. Ela leu bonito esta carta.

(Foltran, 2010: 171)

Concordando com as hipóteses de Larson (1998) e Geuder (2002), Foltran (2010) assume a hipótese de alternância entre predicar de indivíduos ou predicar de eventos, evitando assumir uma mudança de categoria quando há um adjetivo predicando de evento. Além disso, Foltran (2010) assume que a morfologia dos advérbios é de ordem flexional, o que implica deixar de tratar advérbios em -mente como novo lexema, e possibilita tratá-los como uma forma flexionada de um adjetivo, sendo a flexão desencadeada ou não, dependendo do contexto em que tais predicados são colocados na sintaxe. Desse modo, na proposta da autora, adjetivos e advérbios predicativos (adjetivos adverbiais) compõem a categoria $[+\mathrm{N}+\mathrm{V}]$ e propõe que "a estrutura mais plausível para esse adjetivo é aquela que o coloca, em algum lugar da derivação, como irmão de V" (Foltran, 2010: 173) ${ }^{24}$.

As análises das autoras são importantes para a reflexão sobre o estatuto categorial dos advérbios e adjetivos. De acordo com as análises de Lobato (2005; 2008) e de Leung (2007),

\footnotetext{
${ }^{22}$ A autora ressalta que a nomenclatura adjetivo adverbial é inapropriada, mas a utiliza por falta de outra melhor.

${ }^{23}$ Além de haver restrições quanto a operações próprias de objetos diretos, como a propriedade de ser medida do evento (denotando um evento télico /atélico) e as construções passivas (cf. Foltran, 2010: 171-172).

${ }^{24}$ A autora esclarece que não está certa sobre se ele é gerado ali ou se ele se move para essa posição (Foltran, 2010: 173).
} 
advérbios em - mente são categorias lexicais independentes dos adjetivos. Em Foltran (2010), as formações em -mente são adjetivos flexionados. O que depreendemos das propostas é que não temos um elemento que pode funcionar ora como uma categoria, ora como outra (nesse caso, um adjetivo que funciona como advérbio), nem temos uma duplicação desses itens no léxico. Cada categoria possui um conjunto de propriedades que a distingue de outras.

Em relação à análise de Foltran, consideramos ser plausível a hipótese de generalizar o estatuto adjetival para itens em -mente (mais precisamente, advérbios de modo), por compartilharem a propriedade de predicar tanto de evento quanto de indivíduos. Uma questão que se coloca é por que a forma (supostamente) não flexionada é bloqueada como modificadora proposicional. Ou inversamente, por que a forma (supostamente) flexionada é exigida nesses casos:

(102) a. ${ }^{*}$ Esporádico/ Esporadicamente ministro aulas fora de Brasília.

b. *Inteligente/ Inteligentemente ele comentou a reportagem.

Nesse sentido, é o caso de verificar se a manifestação da forma flexionada é determinada por um fator independente - uma questão que merece elaboração.

Tentativamente, gostaríamos de fazer as seguintes ponderações. Em primeiro lugar, vimos que a forma (supostamente) flexionada é obrigatória em contexto de modificação sentencial. Nesse contexto, ocorrem os modificadores do tipo subjetivos, intersubjetivos, veritativos, modais e delimitadores. Entre essas classes, gostaríamos de destacar o caso dos modificadores sentenciais orientados para o sujeito. Esses casos são discutidos por Leung, sendo excluída a possibilidade de uso da forma (supostamente) não-flexionada. No entanto, questionamos essa restrição (e o julgamento da autora para os dados em (95b)). De fato, consideramos que exemplos como Maria falou estúpido/ raivoso/ delicado comigo são possíveis autorizando, portanto, a ocorrência da forma (supostamente) flexionada e nãoflexionada (ou, nos termos de Lobato, o advérbio em -mente e a forma adjetival). Consideramos que esses dados devem ser trazidos para a discussão, uma vez que demonstram:

1. Seja a possibilidade de ter a forma não-flexionada (conforme Foltran 2010), associada a uma propriedade tipicamente da modificação sentencial;

2. Seja a possibilidade de ter a forma adjetival modificadora de um nominal na estrutura conceptual do predicado (conforme Lobato 2008), em que se verifica a orientação para o sujeito, como se depreende da relação de acarretamento 
identificada por Leung (2009) (Se Maria falou raivoso [=com a voz raivosa] acarreta que Maria foi raivosa).

\subsection{Considerações parciais}

Neste capítulo, buscando refletir sobre o estatuto categorial do advérbio, fizemos uma retomada dos estudos sobre essa classe e suas relações com preposições (Lemle, 1984; Bomfim, 1988; Lobato, 1989), com pronomes (Bomfim, 1988) e com adjetivos (Lobato, 2005/ 2008; Leung, 2007; Foltran 2010).

Para Lemle (1984), o advérbio constitui a categoria das preposições, hipótese que ela defende com base na distribuição sintática e semelhança semântica entre advérbios e SPs, além do argumento diacrônico de que o processo de aglutinação de preposição e nomes ou preposição e advérbios conserva o rótulo categorial inicial (SP). No entanto, vimos que a análise de Bomfim (1988) contesta o argumento de distribuição sintática e semelhança semântica de Lemle (1984), pois coloca contextos que permitem o advérbio, mas não permitem SP, tal como (14), reapresentado abaixo:

(14) a. Ele procedeu hipocritamente (=com hipocrisia)

b. Condeno sua atitude hipocritamente amável.

c. *Condeno sua atitude amável com hipocrisia.

Bomfim também rejeita o tratamento dos advérbios como preposições, proposto por Lemle (1984), apoiando-se nos seguintes argumentos: 1) advérbios podem ser intensificados, preposições não; 2) uma preposição relaciona dois termos e pode vir precedida de praticamente todas as classes gramaticais, com exceção de outra preposição ou de uma conjunção; 3) preposições exigem a forma tônica do pronome subsequente, mas nos casos de advérbios como dentro, perto, é o ponto de referência que é necessariamente precedido por preposição, e é ela que exige a forma tônica do pronome; e 4) advérbios e SPs podem se realizar em contextos idênticos, mas a autora ressalta a necessidade de distinguir classe e função, pois o fato de poderem exercer a mesma função, não implica dizer que advérbios são preposições.

Lobato (1989) dialoga com as propostas de Lemle (1984) e Bomfim (1988). A autora, partindo da distinção entre verdadeiras preposições e preposição marcadora de Caso, demonstra que palavras como dentro, perto são uma categoria, denominada advérbio, no nível de nomes e adjetivos quanto à incapacidade de realizar Caso, capacidade que as preposições, 
assim como os verbos, possuem, não sendo razoável, por isso, incluir palavras como dentro, perto na classe das preposições. Quanto à questão de incidência ou não de intensificadores, proposta por Bomfim (1988), Lobato (1989) afirma que a questão que faz a diferença não é essa, mas é o fato de preposições não aceitarem a incidência de intensificadores só sobre elas, uma vez que preposições não admitem complemento não manifesto; assim, a verdadeira diferença está no fato de que, enquanto o complemento da preposição é obrigatoriamente manifesto, os advérbios permitem a não manifestação lexical do seu complemento. Além disso, Lobato (1989) utiliza também o argumento da convenção pied-piping para manter o tratamento de palavras como dentro, perto como advérbios: as preposições, em português, precisam se deslocar junto com o sintagma que integram, já no caso dos advérbios, o piedpiping não é necessário.

Com todos esses argumentos, Lobato (1989) retém da análise de Bomfim (1988) a classificação desses elementos como advérbios e não como preposições, mas não retém o tratamento de estruturas como adiante de como locuções prepositivas ou SPs, uma vez que trata de como preposição marcadora de Caso e, assim, não teríamos um SP encaixado, mas uma projeção direta de um advérbio que possui um SN complemento, surgindo o elemento de pela necessidade de o SN complemento receber Caso. Da análise de Lemle (1984), Lobato (1989) retém a ideia de que seria mais adequado tratar esses elementos como uma classe apenas, e não incluí-los em classes distintas, como o faz a tradição. No entanto, na proposta de Lobato, essa unificação do tratamento das ocorrências em questão se dá em relação à classificação de advérbios, em qualquer função, esses elementos são advérbios. Lobato (1989) retém também de Lemle (1984) a proposta sobre a generalização intercategorial referente à complementação dos elementos, mas Lobato se refere a advérbios, não a preposições.

Lobato (1995) novamente retoma a questão "advérbios versus preposição" e mantém a hipótese de que itens como adiante são advérbios, mas concorda com Bomfim (1988) em que itens como adiante de mim são SPs. Nesse caso, o estatuto preposicional é determinado pelo elemento 'de', analisado como preposição marcadora de Caso, enquanto 'adiante' mantém o estatuto de advérbio.

Retomamos a proposta de Bomfim (1988), ainda na discussão quanto ao estatuto categorial, mas considerando, em particular, aqueles advérbios que manifestam interpretação locativa e temporal, observando a posição que podem ocupar na oração, em que se destaca a possibilidade de ocorrerem na posição de sujeito. A autora demonstra que advérbios de tempo e lugar possuem um comportamento sintático distinto dos demais e, mais particularmente, que advérbios de tempo como ontem, hoje, amanhã possuem propriedades distintas de advérbios 
como cedo e tarde. Para a autora, os advérbios com propriedades dêiticas estariam mais bem classificados como pronomes, por serem dêiticos, substituírem sintagmas nominais e ocuparem posição de sujeito. Nesse sentido, advérbios locativos e temporais podem ser discutidos em termos desse estatuto pronominal do advérbio, que viabiliza sua ocorrência como sujeito em predicados descritivos e como sujeito/ predicativo em predicados equativos, respectivamente. Essa questão será retomada no capítulo 4.

Em seguida, passamos a discutir dados como 'O carro anda rápido/rapidamente', abordando a questão categorial, do ponto de vista da relação entre o adjetivo e o advérbio, considerando particularmente a análise de Lobato (2008), em que a autora discute análises prévias e sistematiza propriedades que determinam a distribuição das formas reduzidas e das formas em -mente. A autora argumenta, em sua análise, que, em dados como 'andar rápido/rapidamente', não temos adjetivos em função adverbial, mas genuínos adjetivos em função de adjetivo, pois eles têm como escopo um sintagma nominal (implícito) na estrutura do predicado, e não o sintagma verbal, como proposto em vários estudos examinados pela autora, com diferentes soluções teóricas.

Os trabalhos de Leung (2007) e Foltran (2010) questionam a hipótese de Lobato (2008) sobre a propriedade nominal às quais os adjetivos adverbiais predicariam. No entanto, temos duas posições distintas: Leung (2007) busca refinar a proposta de Lobato, delineando os contextos verbais nos quais as construções com PAs ocorreriam: apenas com verbos que denotam atividade, que possuem uma semântica de produção, ou seja, que licenciam um objeto cognato eventivo; enquanto Foltran (2010) propõe que os dados sejam analisados por outro viés: ao invés da predicação de uma propriedade nominal na estrutura do sintagma verbal, a autora orienta a discussão para uma hipótese em que a classe dos elementos $[+\mathrm{N}+\mathrm{V}]$ inclui adjetivos e advérbios predicativos (especificamente, os de modo). Enquanto a proposta de Lobato (refinada por Leung) mantém a identidade das categorias (cada uma com suas propriedades: advérbio continua sendo advérbio e adjetivo continua sendo adjetivo), a proposta de Foltran reúne o que é tratado pela tradição como duas classes de palavras distintas numa categoria $[+\mathrm{N}+\mathrm{V}]$, sendo as formas em -mente um tipo de adjetivo flexionado.

No próximo capítulo, aprofundaremos a nossa discussão, observando como a distribuição do advérbio na estrutura oracional pode contribuir para a reflexão sobre o seu estatuto. Para tanto, retomamos o estudo seminal de Jackendoff (1972) acerca da distribuição dos advérbios na estrutura oracional do inglês e examinamos as observações desse autor, relacionando-as ao português, tomando como referência o estudo de Gonzaga (1997). Em seguida, apresentamos a proposta de Cinque (1999) para a tipologia dos advérbios em francês 
e italiano, em que é adotada uma abordagem cartográfica para a distribuição desses elementos na estrutura oracional. Trazemos também a análise de Costa (2008), que avalia as implicações das generalizações da abordagem cartográfica de Cinque (1999), e a proposta de Pereira (2011), que adota a hipótese de Cinque (1999) e propõe que o advérbio "lá", discursivamente marcado, no PB, é realizado como especificador de núcleos funcionais. 


\section{CAPÍTULO 3 \\ A DISTRIBUIÇÃO DOS ADVÉRBIOS NA ESTRUTURA ORACIONAL}

Neste capítulo, daremos continuidade à reflexão sobre o estatuto categorial do advérbio, mas observando sua distribuição sintática na estrutura oracional. Para tanto, retornamos aos estudos de Jackendoff (1972), que faz uma análise dos advérbios na língua inglesa, e refletimos sobre as aplicações de sua análise ao PB, a partir do estudo de Gonzaga (1997). Fazemos também uma exposição dos estudos de Cinque (1999) sobre os advérbios no francês e no italiano, seguindo com uma reflexão de Costa (2008), que baseia-se em Ernst (1984, 2002), sobre a proposta cartográfica de Cinque (1999). Por último, ilustramos a aplicação da proposta de Cinque para o PB, a partir do estudo de Pereira (2011), que faz uma análise de "lá" como especificador de núcleos funcionais.

\subsection{Advérbios: estrutura e informação veiculada - Jackendoff (1972)}

Jackendoff (1972) faz uma análise dos advérbios na língua inglesa, ressaltando a dificuldade em compreender essa categoria devido à variedade de seus papéis sintáticos e semânticos. O autor coloca a importância de um estudo que busque reduzir o número das várias relações gramaticais em que alguns advérbios aparecem. Assim, assume uma abordagem que vincula a informação de cada advérbio e as características sintáticas das estruturas onde ocorre. $\mathrm{O}$ autor propõe que, para advérbios do inglês com o sufixo -ly, existem três posições básicas na sentença: posição inicial, posição final sem pausa e posição auxiliar (entre o sujeito e o verbo principal); e, dessas três posições básicas, distinguem-se várias classes. A primeira classe pode ocupar as três posições, mas com mudança de sentido, como ocorre com clumsily, carefully, carelessly, happily, truthfully, specifically, frankly and cleverly.

(1) a. John clumsily dropped his cup of coffee.

John desajeitadamente derramou seu café.

b. Clumsily (,) John dropped his cup of coffee.

c. John dropped his cup of coffee clumsily.

Em (1a) há ambiguidade, pois pode significar (1b ou c), que podem ser parafraseadas como $(2 \mathrm{a}, \mathrm{b})$ respectivamente: 
(2) a. It was clumsy of John to drop his cup of coffee.

b. The manner in which John dropped his cup of coffee was clumsy.

Os advérbios que podem ocupar as três posições, sem mudança de sentido, como quickly, slowly, reluctantly, sadly, quietly, indolently, frequently, immediately, often, soon, compõem uma segunda classe.

A terceira classe é composta por advérbios que ocorrem somente nas posições inicial e auxiliar, como probably, evidently, unbelievably, certainly, understandably, unfortunately, naturally, apparently.

(3) a. Probably Horatio has lost his mind.

Provavelmente Horatio perdeu a cabeça.

b. Horatio has probably lost his mind.

c. *Horatio has lost his mind probably.

Frequentemente, esses advérbios na posição final ficam gramaticais se estiverem acompanhados de pausa:

(4) Horatio has lost his mind, probably.

A quarta classe pode ocorrer somente na posição auxiliar e na posição final, como completely, purposefully, totally, altogether, handily, badly, mortally, tremendously:

(5) a. *Completely Stanley ate his Wheaties.

Completamente Stanley comeu seu cereal.

b. Stanley completely ate his Wheaties.

c. Stanley ate his Wheaties completely.

Outros advérbios, em que não é utilizado tipicamente o sufixo -ly, ocorrem somente em posição final, compondo a quinta classe, como well, hard, more, less, before, early, fast, home, slow, terribly, lenghwise, indoors, downstairs:

(6) a. Sam did his work well.

Sam fez o seu trabalho bem. 

b. *Well Sam did his work.
c. *Sam well did his work.

Finalmente, a sexta classe ocorre somente em posição auxiliar, como truly, merely, simply, utterly, virtually, hardly, scarcely:

(7) a. Albert is truly being a fool.

Albert verdadeiramente é um tolo.

b. *Truly Albert is being a fool.

c. *Albert is being a fool truly.

Além de estabelecer as três posições básicas, o autor coloca a possibilidade de alguns advérbios ocorrerem dentro do VP. Os advérbios dominados por S são marcados com um traço extra [+transportável], enquanto os dominados por VP, por serem selecionados, não podem mover-se livremente.

Semanticamente, o autor considera que advérbios orientados para o falante ou para o sujeito da sentença são dominados por $\mathrm{S}$ e, tipicamente, ocupam posição inicial, posição auxiliar e posição final com pausa, como ilustram os dados abaixo:

(8) a. Evidently John ate the beans.

b. John evidently ate the beans.

c. John ate the beans, evidently.

O autor considera advérbios com interpretação de modo como advérbios de VP. Eles podem ocupar posição final sem pausa e posição auxiliar e, neste caso, além da interpretação de modo, pode haver uma interpretação de orientação para o falante ou para o sujeito da sentença (ambiguidade estrutural):

(9) a. John ate the beans completely.

b. John completely ate the beans.

Advérbios de VP e advérbios de $\mathrm{S}$ distinguem-se quanto à posição auxiliar quando estão diante de um verbo modal ou de um verbo auxiliar. Os advérbios de $\mathrm{S}$ podem ocorrer 
em posição auxiliar e depois dos modais ou dos auxiliares, enquanto advérbios de VP não podem ocorrer em posição auxiliar:

(10) a. George probably has read the book.

b. *George completely has read the book.

c. George has probably read the book.

d. George has completely read the book.

Se houver dois auxiliaries ou modais, entre eles ocorrerá, preferencialmente, um advérbio de S; mas, depois deles, ocorrerá um advérbio de VP, dada a propriedade de transportabilidade de advérbios de $\mathrm{S}$ e a restrição de movimento de advérbios de VP:

(11) a. George will probably have read the book.

b. ?/*George will completely have read the book.

c. *George will have probably read the book.

d. George will have completely read the book.

A análise de Jackendoff (1972) é muito relevante, pois abandona uma classificação dos advérbios baseada em critérios exclusivamente semânticos, relacionando as informações semânticas com as posições sintáticas em que ocorrem.

Na próxima seção, traremos a análise de Gonzaga (1997), que verifica a aplicação das hipóteses de Jackendoff (1972) ao português.

\subsubsection{A análise de Jackendoff (1972) e suas aplicações ao português}

Testando as hipóteses de Jackendoff (1972) no português, Gonzaga (1997) observa que alguns advérbios também podem ocupar as três posições (inicial, final, auxiliar). No entanto, podem ocorrer com ou sem pausa na posição inicial, conforme ilustram os dados (12b) e final (12c), retirados de Gonzaga (1997: 31). Nos estudos de Bomfim (1998), observamos que o fato de haver pausa no início ou no final, no PB, significa que a opinião do locutor está sendo expressa; quando não há pausa, trata-se de um advérbio oracional.

(12) a. O João desastradamente deixou cair o café.

b. Desastradamente (,) o João deixou cair o café.

c. O João deixou cair o café (,) desastradamente. 
A primeira classe proposta pelo autor (advérbios que podem ocupar as três posições, com mudança de sentido) se aplica ao PB, mas não somente com advérbios com o sufixo mente. Além disso, notamos também que no PB há uma posição a mais: o advérbio pode ocorrer entre o verbo e seu complemento (cf. 13c):

(13) a. Apenas a garota folheou o livro.

b. A garota apenas folheou o livro.

c. A garota folheou apenas o livro.

d. A garota folheou o livro apenas.

Em (13a), temos uma leitura de restrição relativa à garota: apenas a garota, e não o garoto, por exemplo, folheou o livro; em (13b), a leitura é de que apenas se refere ao verbo, apenas folheou, não o leu; em $(13 \mathrm{c}, \mathrm{d})$, a leitura é de referência ao NP o livro: apenas o livro ou o livro apenas, e não o jornal, a revista.

Existem também no $\mathrm{PB}$ advérbios que podem ocupar as três posições básicas propostas por Jackendoff, sem mudança de sentido (mas, no caso do PB, quatro posições básicas, tendo em vista a possibilidade de ocorrência entre o verbo e o complemento, citada anteriormente):

(14) a. Rapidamente eu fiz o almoço.

b. Eu rapidamente fiz o almoço.

c. Eu fiz rapidamente o almoço.

d. Eu fiz o almoço rapidamente.

Quanto aos advérbios que ocorrem apenas em posição final e de auxiliar (entre o sujeito e o verbo principal) no inglês, existe a correspondência em $\mathrm{PB}$, no que diz respeito à restrição na posição inicial (15a). No entanto, um contraste se manifesta de forma interessante, pois existe restrição, no PB, à ocorrência do advérbio na posição entre o sujeito e o verbo, permitida em inglês, mas o PB tem a possibilidade já apontada de ocorrência entre o verbo e o complemento. No entanto, com advérbios como completamente, há restrição na posição entre sujeito e verbo (15c), que não ocorre no inglês (15d):

(15) a. * Completamente decorei meu quarto.

b. Decorei completamente a casa. 
c. *Eu completamente decorei a casa.

d. Stanley completely ate his Wheaties.

Gonzaga (1997) aponta ainda uma diferença na ocorrência do advérbio completamente com os verbos comer e comprar. No português, não apenas é impossível a ocorrência de completamente entre o sujeito e o verbo, no caso do verbo comer, como também é impossível em qualquer outra posição no caso do verbo comprar:

(16) a. O João comeu completamente o bolo

b. O João comeu o bolo completamente.

c. *O João comprou completamente o bolo.

d. *O João comprou o bolo completamente.

Advérbios que, em inglês, ocorrem apenas em posição final (well), em PB podem ocorrer também na posição pós-verbal:

(17) a. Maria fez bem a prova.

b. Maria fez a prova bem.

c. *Maria bem fez a prova.

d. *Bem Maria fez a prova.

Gonzaga (1997) observa que a ocorrência de advérbios como bem em posição final no português está relacionada à complexidade do NP objeto, ou ao seu caráter "pesado" (“heavy NP shift”), pois, quando o complemento é modificado por uma frase, o advérbio ocupa, preferencialmente, a posição pós-verbal:

(18) a. ?? O João fez [o trabalho [que tu lhe pediste a semana passada]] bem.

b. O João fez bem [o trabalho [que tu lhe pediste a semana passada]].

No que diz respeito aos advérbios que, em inglês, ocorrem apenas em posição auxiliar, também teremos observações: no PB, esse tipo advérbio pode ocorrer também em posição inicial e final com pausa:

(19) a. O João simplesmente é um tolo. 
b. O João é simplesmente um tolo.
c. O João é um tolo, simplesmente.
d. Simplesmente, o João é um tolo.

Como vimos na análise de Jackendoff (1972), a maior ou menor mobilidade dos advérbios dentro da oração pode ser também explicada a partir da sintaxe, na qual se distinguem advérbios selecionados (de VP) e advérbios sentenciais, estes últimos com mais mobilidade. Os advérbios de VP só podem se referir ao verbo ou a qualquer dos argumentos internos ao VP: especificador e complemento. A distribuição dos advérbios na estrutura oracional e as implicações para a caracterização dos elementos que integram esta classe serão retomadas na próxima seção, com o estudo de Cinque (1999), que considera primordialmente o italiano e o francês.

Um aspecto que merece destaque, do ponto de vista translinguístico, é a diferença entre o inglês e o português, em relação à ocorrência do advérbio entre o verbo e o complemento, possível neste, mas não naquele. Descritivamente, foi possível demonstrar dois aspectos interessantes: em primeiro lugar, a distribuição do advérbio completely/ completamente, que ocorre em posição pré-verbal, em inglês, mas não em português, embora, no português, seja encontrado entre o verbo e o complemento, mas não em inglês, com significado idêntico. Em segundo lugar, a distribuição de advérbios como well/ bem, que em inglês ocorrem apenas em posição final, em português, são encontrados adicionalmente na posição entre o verbo e o complemento.

Conclui-se que a posição do advérbio entre o verbo o complemento tem um correlato tanto na posição final, como na posição pré-verbal. Nossa hipótese de trabalho é a de que essa equivalência constitui uma condição necessária para que o advérbio de VP seja deslocado para a posição de sujeito no PB. A previsão é, portanto, que em línguas que restringem a ocorrência do advérbio entre o verbo e o complemento, essa estrutura não ocorre. Essa questão será retomada no Capítulo 4. 


\subsection{Advérbios de VP e advérbios sentenciais: a contribuição de Cinque (1999) em questão}

Cinque (1999) ${ }^{25}$ traz uma nova perspectiva sob a qual se pode olhar os advérbios, pois questiona a caracterização tradicional dessa classe como acessória (adjunto). O autor propõe que os advérbios são especificadores de categorias funcionais e, como tal, checam traços do núcleo dessas categorias.

Um exame acurado das propriedades sintáticas e semânticas de advérbios em francês e italiano permite ao autor distinguir duas classes: os advérbios de VP (mais baixos) e os advérbios sentenciais (mais altos). Examinando o deslocamento dos advérbios em diferentes posições na oração, Cinque demonstra que os advérbios mais baixos possuem uma ordem relativa fixa, enquanto os advérbios oracionais manifestam mobilidade, embora alguns contrastes relevantes sejam observados.

Dessa maneira, o autor observa que advérbios habituais do italiano como solitamente 'normalmente' precedem o advérbio de negação mica 'NEG'; se solitamente estiver posposto a mica, o resultado é uma frase agramatical, como se pode conferir nos exemplos abaixo:

(20) a. Alle due, Gianni non ha solitamente mica mangiato, ancora.

'At two, G. has usually no eaten yet.'

b.*Alle due, Gianni non ha mica solitamente mangiato, ancora.

'At two, G. has no usually eaten yet'.

(Cinque, 1999: 4)

Essa ordem também é verdadeira para o francês:

(21) a. A deux heures, Gianni n'a généralement pas mangé, encore.

b. *A deux heures, Gianni n'a pas généralement mangé, encore.

(Cinque, 1999: 5)

Em italiano (22a, b), o advérbio negativo mica necessariamente precede o advérbio già (já), assim como, em francês (22c, d), pas (não) e déjà (já) apresentam a mesma ordem:

(22) a. Non hanno mica già chiamato, che io sappia.

\footnotetext{
${ }^{25}$ Agradecemos à professora Marina Augusto por, na ocasião do Encontro Nacional do Grupo de Trabalho de Teoria da Gramática/ GTTG - Anpoll, 2011, ter apontado a relevância de Cinque (1999) para a presente discussão.
} 
'They have not already telephoned, that I know.'

b. *Non hanno già mica chiamato, che io sappia.

'They have already not telephoned, that I know.'

c. Si tu n'as pas déjà mangé, tu peux le prendre.

'If you have not already eaten, you can take it.'

d. *Si tu n'as déjà pás mangé, tu peux le prendre.

'If you have already note aten, you can take it.'

(Cinque, 1999: 5)

Seguindo este modelo de teste, Cinque chega à conclusão de que a ordem relativa dos advérbios mais baixos pode ser ilustrada pela sequência abaixo, em que cada elemento relacionado representa uma classe de advérbios:

(23) a. Solitamente> mica > già > più > sempre> completamente> tutto>bene

b. généralement $>$ pás $>$ déjà $>$ plus $>$ toujours $>$ complètement $>$ tout $>$ bien

(Cinque, 1999: 11)

Assim como os advérbios mais baixos, os advérbios mais altos também são caracterizados por uma ordem relativa. Segundo Cinque (1999), de acordo com Jackendoff (1972), advérbios orientados para o sujeito como intelligently (inteligentemente) e clumsily (desajeitadamente) seguem advérbios orientados para o falante como probably (provavelmente). A classe de advérbios orientados para o falante, no entanto, não é homogênea, o que permite nova divisão em classes, como propõe Bellert (1977, apud Cinque 1999: 11), considerando aspectos sintáticos e semânticos:

(24) a. domain adverbs: politically, legally.

b. pragmatic adverbs: frankly, sincerely, honestly.

c. evaluative adverbs: luckily, fortunately, happily.

d. modal adverbs: probably, presumably.

e. perhaps.

Com a proposta de Bellert, pode-se observar que os advérbios de cada categoria em (24) podem co-ocorrer em uma determinada ordem, fato não esperado se eles fossem membros de uma mesma classe. Cinque aponta que, além de preceder advérbios de orientação para o sujeito, forse 'talvez' segue advérbios modais, como probabilmente 'provavelmente': 
(25) a. Gianni sarà probabilmente forse ancora in grado di aiutarci.

'G. will probably perhaps still be able to help us.'

b. *Gianni sarà forse probabilmente ancora in grado di aiutarci.

'G. will perhaps probably still be able to help us.'

(Cinque: 1999:12)

Advérbios modais seguem advérbios avaliativos (26a, b); e advérbios avaliativos, por sua vez, seguem advérbios pragmáticos $(26 c, d)$ :

(26) a. Gianni ha per fortuna probabilmente accettado.

'G. has luckily probably accepted.'

b. *Gianne ha probabilmente per fortuna accettado.

'G. has probably luckily accepted.'

c. Francamente ho purtroppo una pessima opinione di voi.

'Frankly I have unfortunately a very bad opinion of you.'

e. *Purtroppo ho francamente una pessima opinione di voi.

'Unfortunately I have frankly a very bad opinion of you.' (Cinque, 1999: 12)

Além das classes de advérbios mais altos já mencionadas, Cinque chama a atenção para advérbios temporais ancorados ao tempo de fala, como ora, adesso (agora) e allora (depois), que possuem maior liberdade de distribuição, podendo seguir ou preceder advérbios modais, avaliativos e pragmáticos:

(27) a. Probabilmente ora ci ascolterà.

'(S)he probably now will listen to us.'

b.Ora probabilmente ci ascolterà.

'(S)he now probably will listen to us.'

(28) a. Fortunatamente ora sei con noi.

'Luckily now you are with us.'

b.Ora fortunatamente sei con noi.

'Now luckily you are with us.'

(29) a. Francamente ora mi hai stufato. 
'Frankly now you have annoyed me.'

b.Ora francamente mi hai stufato.

'Now frankly you have annoyed me.'

No entanto, tais advérbios podem aparecer somente à esquerda de forse 'talvez' e de advérbios orientados para o sujeito:

(30) a. Gianni è ora forse partito.

'G. has now perhaps left.'

b. * Gianni è forse ora partito.

'G. has perhaps now left.'

(31) a. Gianni ha ora saggiamente ceduto.

'G. has now wisely surrendered.'

b. *Gianni há saggiamente ora ceduto.

'G. has wisely now surrendered.'

Segundo Cinque, os dados acima nos dão a seguinte ordem para os advérbios mais altos:

(32) a. francamente> fortunatamente $>$ evidentemente $>$ probabilmente $>$ ora $>$ forse > intelligentemente.

b. franchement> heureusement> évidemment> probablement> maintenant> peut être> intelligentement. ${ }^{26}$

(Cinque, 1999: 13)

A análise de Cinque faz uma previsão de correspondência um a um entre o tipo de advérbio e a hierarquia de especificadores adverbiais e os núcleos funcionais das sentenças. Tendo em vista os testes propostos, o autor postula a seguinte estrutura hierárquica (Cinque, 1999: 106):

(33) The universal hierarchy of clausal functional projections

\footnotetext{
${ }^{26}$ Cinque (1999, p.12-13) demonstra que o francês manifesta os mesmos contrastes, autorizando uma hierarquia como a do italiano.
} 
[frankly Mood $_{\text {speech act }}$ [fortunalely Mood $_{\text {evaluative }}$ [allegedly Mood $_{\text {evidential }}$ [probably Mod $_{\text {epistemic [once T(Past) [then T(Future) [perhaps Mood }}$ irrealis [necessarily

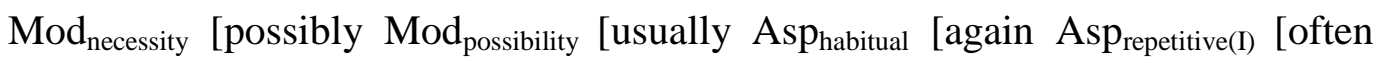
$\mathrm{Asp}_{\text {frequentative(I) }} \quad$ [intentionally $\operatorname{Mod}_{\text {volitional }}$ [quickly Asp celerative(I) [already

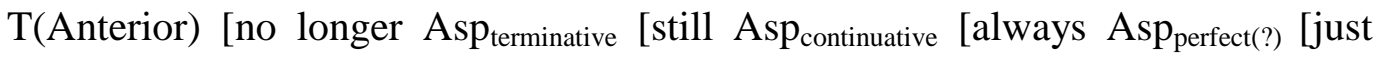

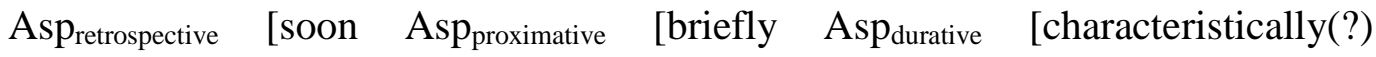

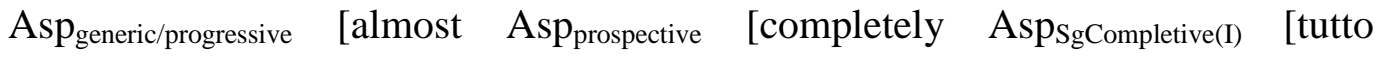

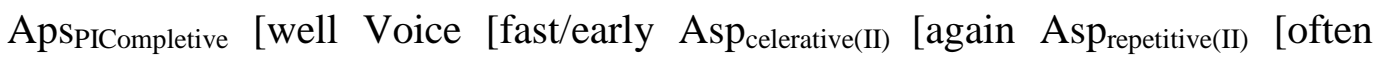
Asp $_{\text {frequentative(II) }}$ [completely Asp $\mathrm{sgCompletive(II)}_{\text {Sg }}$

O autor observa que as línguas são geralmente mais ricas na realização de diferentes classes de AdvPs do que na realização de núcleos correspondentes, embora haja exceções. Nesse sentido, se cada classe de advérbio de fato corresponde a diferentes núcleos funcionais, então, há evidências de que a matriz inteira de núcleos funcionais (e projeções) está disponível, bem como os respectivos especificadores, mesmo que não haja morfologia evidente correspondente aos núcleos.

\subsubsection{Advérbios de VP: sobre os circunstanciais}

De acordo com Cinque (1999), advérbios circunstanciais que seguem o complemento do verbo possuem um comportamento diferente dos advérbios sentenciais/predicativos, compreendendo uma variedade de elementos que codificam diferentes significações a saber: modo, lugar e tempo; realizando-se, por hipótese, dentro do VP. Como modificadores do predicado, não são rigidamente ordenados um em relação ao outro, sendo intercambiáveis, embora haja distinção de interpretação decorrente do escopo. Assim, em (34a), a expressão adverbial de lugar tem escopo sobre a expressão adverbial de tempo, e em (34b), verifica-se que a expressão adverbial de tempo tem escopo sobre a expressão de lugar:

(34) a. He attended classes every day of the week in a different university.

b. He attended classes in each university on a different day of the week.

(Cinque, 1999: 28)

Para o autor, adverbiais circunstanciais que seguem o complemento são predicados de $\mathrm{VP}$, o que leva a atribuir uma estrutura como (36) para dados como (35), onde 'at the 
university' é predicado do VP 'John attended classes', e 'every day' é predicado de um VP maior 'John attended classes at the university' (Cinque, 1999: 29):

(35) John attended classes at the university every day.

(36)
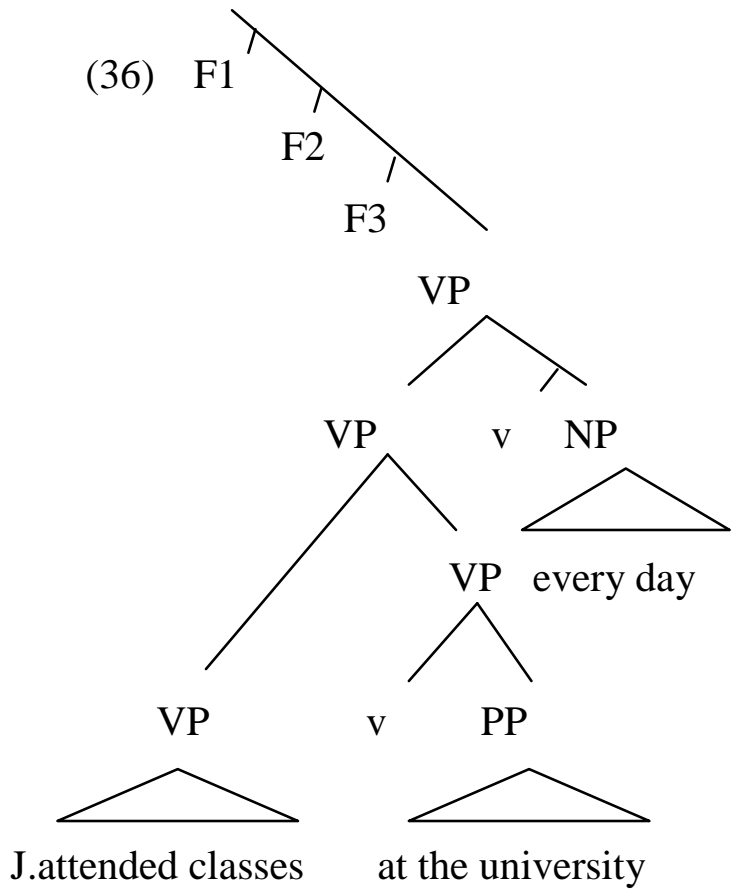

O autor observa que uma variante dessa ideia é considerar a configuração em (36) como derivada de uma estrutura subjacente como (37), com o PP adverbial no spec de uma concha de VP distinta, seguido de sucessivos movimentos obrigatórios à esquerda do VP mais baixo para o especificador mais alto (talvez para estabelecer a predicação requerida) (Cinque, 1999: 30):

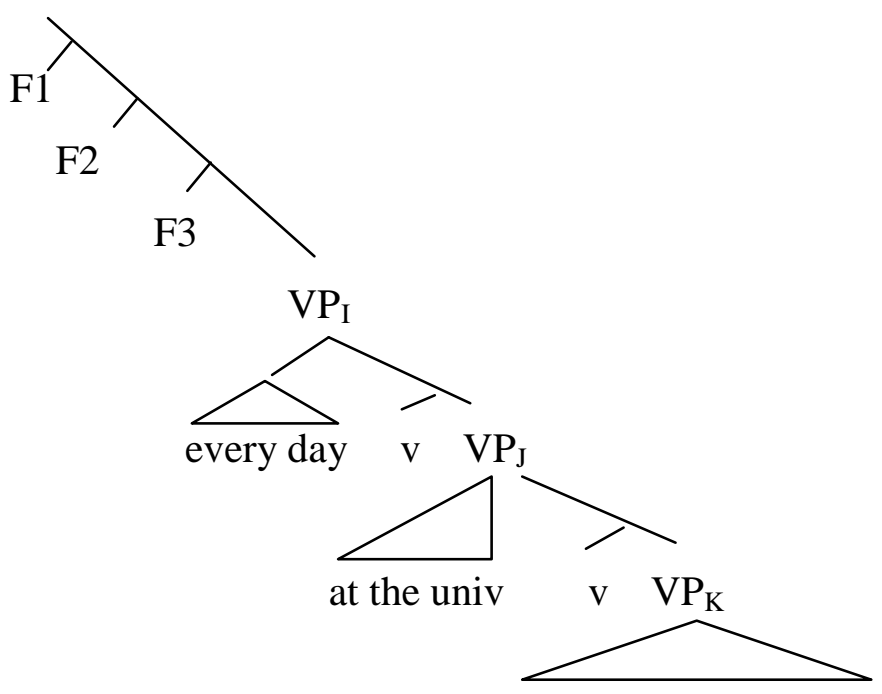

John attended classes 
As expressões adverbiais de circunstância também se distinguem dos sintagmas adverbiais canônicos (propriamente ditos) ${ }^{27}$, que compreendem os advérbios mais altos e os mais baixos citados na seção anterior, porque podem ser realizadas por sintagma preposicional (por três horas, na cozinha, com grande zelo, por seu amor, com a bicicleta, de uma maneira rude, etc), ou em forma de NP (um dia depois, amanhã, neste lugar, aqui, etc.). Possivelmente como consequência disso, eles não podem aparecer em qualquer das posições pré-VP abertas aos advérbios típicos/canônicos (exceto em posição inicial de tópico). Enquanto estes são caracteristicamente operadores, as expressões adverbiais de tempo e lugar podem ser vistas como modificadoras de predicado de uma variável de evento subjacente. Se advérbios típicos/canônicos ocupam a posição de especificador de projeções funcionais distintas acima de VP e o mesmo não acontece para os adverbiais circunstanciais, entre eles, os de tempo e lugar, é natural que a ordem rígida de advérbios seja uma consequência (via Spec/head agreement) da ordem de seus respectivos núcleos funcionais. Assim, a ordem livre dos circunstanciais se correlacionaria com o fato de eles não serem gerados na posição de especificador de projeções funcionais.

Entre os advérbios apontados por Cinque (1999) como circunstanciais, nos interessam, mais especificamente, os de lugar, que discutiremos no capítulo 4, pois, demonstram um comportamento sintático específico.

Vimos que, de acordo com Cinque (1999), advérbios são realizados como especificadores de núcleos funcionais na estrutura oracional, o que se sustenta pela observação de que as diferentes classes de AdvPs e sua ordem relativa parecem combinar, nas línguas do mundo, em relação ao número, ao tipo e à ordem relativa dos morfemas que realizam os núcleos funcionais. Várias críticas a esse modelo têm surgido, seja do ponto de vista conceitual ou técnico, como veremos a seguir em Ernst (2002) e Costa (2008).

Ernst (2002: p 13) defende que as ordens relativas entre advérbios são determinadas por relações de escopo (as quais se definem na interface conceitual-intencional) e são expressas na sintaxe por adjunção às categorias relevantes. Na maioria dos casos, conforme observa o autor (cf. ERNST 2010, p. 183) "adverbials may adjoin wherever they receive their proper interpretation, [which is] determined in part by the lexical requirements of the

\footnotetext{
${ }^{27}$ No original "AdvP proper".
} 
adverbial in question, by the requirements of other lexical items, and by general principles of semantic composition for adverbials". ${ }^{28}$

Em sua análise, os adjuntos que participam de relações de escopo (referidos como adjuntos predicacionais) selecionam proposições ou eventos, mediante o cálculo FEO (FACTEVENT-OBJECT), o qual corresponde a zonas ordenadas da estrutura oracional. Dada essa configuração, os diferentes tipos de adjuntos permitem identificar os seguintes níveis de ordenamento: ato-de-fala > fato > proposição > evento > evento especificado. Aos diferentes níveis correspondem os diferentes tipos de advérbios (predicacionais), assim ordenados: 'orientados para o discurso' > 'avaliativos' > 'modais' > 'evidenciais' > 'orientados para o sujeito'> 'modo', embora a posição relativa dos adjuntos em cada zona seja decorrente das relações de escopo, e não da associação a um tipo de posição sintática. Ernst (2002, p. 143) distingue ainda os adjuntos do tipo 'participantes', que incluem locativos, instrumentais e benefactivos, e que não têm exigências de escopo, e os adjuntos/ advérbios funcionais, como advérbios de negação, tempo, frequência, que manifestam relações fracas de escopo.

Em relação a essas objeções, Cinque (2004) observa que, mesmo sendo consensual que exista uma necessidade semântica de que algumas noções estejam no escopo de outras, por determinação de um princípio semântico da interface conceitual-intencional, isso não implica que a sintaxe estreita (narrow syntax) seja amorfa, em relação a essas propriedades. Em particular, considera que as abordagens baseadas na adjunção devem especificar claramente as propriedades lexicais e semânticas das diferentes classes de advérbios, pelas quais se definem as relações de escopo e os pontos de adjunção, o que não foi suficientemente alcançado na teoria linguística.

Cinque observa ainda que a abordagem baseada na adjunção livre não tem nada a dizer a respeito das classes de advérbios, que se manifestam de maneira uniforme nas línguas do mundo. Em sua argumentação, alega que existem muitas noções no repertório conceitualintencional que poderiam ser gramaticalizadas, mas não o são, cabendo reconhecer que as noções existentes correspondem a distinções funcionais fornecidas pela GU (por um acidente evolutivo), assim como a relação com as classes de advérbios correspondentes (conforme propõe o modelo baseado em sua inserção como especificadores). Diante disso, conclui:

\footnotetext{
28 “(...) advérbios podem adjungir-se onde quer que recebam a respectiva interpretação, a qual é determinada em parte pelas exigências lexicais do advérbio em questão, pelas exigências de outros itens lexicais, e por princípios gerais da composição semântica para adverbiais" [tradução minha].
} 
“(...) it seems reasonable to require that there be a formal means to relate the functional head distinctions to the corresponding AdvP distinctions, irrespective of the possibility that the relative scope relations among such UG entities ultimately reflect a more general cognitive order of scope among them. ${ }^{29}$ (Cinque, 2004: 34)

Além disso, ainda segundo Cinque (2004), a proposta da adjunção, em que a ordem relativa de advérbios é baseada em relações de escopo, nada tem a dizer a respeito da ordem relativa entre um advérbio e o verbo, ou entre um advérbio e um dos complementos da oração, uma vez que tais relações não se prestam a uma análise em termos de escopo. Nesse aspecto, faz referência ao caso das línguas românicas, em que a ordem do advérbio em relação ao verbo, além de variar de língua para língua, é determinada pela a forma do verbo (finita, infinitiva, participial).

A escolha entre as propostas citadas é uma decisão a ser tomada com base em argumentos conceituais, teóricos e empíricos, estando o debate ainda em aberto em relação a várias questões. Do ponto de vista dos questionamentos deste trabalho, as hipóteses formuladas confirmam a necessidade de postular a categoria advérbio, em oposição às demais classes (lexicais) - independentemente de sua manifestação (ou a de suas subclasses) estar associada ao léxico funcional e/ou substantivo. Conforme mencionado, será discutido, no próximo capítulo, o problema da ocorrência de advérbios (circunstanciais) na posição de sujeito. Como será demonstrado, as propriedades sintáticas desses advérbios não colocam os problemas teóricos apontados na análise dos advérbios predicacionais, sendo esse aspecto crucial para a análise a ser proposta para essas construções - uma vez que a mobilidade do advérbio não trará mudança de significado.

Antes de abordar essa questão, vamos ainda nos deter em alguns aspectos da sintaxe dos advérbios no português, o que nos permitirá demonstrar a complexidade dessa categoria e dos traços (formais e semânticos) que realiza.

\subsubsection{A relação entre o mapeamento sintático e a interpretação semântica do advérbio em português: Costa (2008)}

Em estudo que examina a proposta de Cinque (1999), Costa (2008) observa que, além do domínio de aplicação pelo qual se distinguem os advérbios sentenciais e modificadores de

\footnotetext{
29 “(...) parece razoável exigir que existam meios formais de relacionar distinções no nível dos núcleos funcionais às distinções correspondents no nível dos sintagmas adverbiais (AdvP), independentemente da possibilidade de que as relações de escopo relativo entre essas entidades da GU reflitam, em última análise, uma ordem cognitiva mais geral de escopo entre elas.” [tradução minha]
} 
VP, fatores adicionais devem ser considerados, como o significado lexical do advérbio (que pode ser inerente ou não-inerente, sendo o primeiro associado a maior flexibilidade sintática). Assim, se o sentido do advérbio não é especificado no léxico, como é o caso de advérbios ambíguos, seu sentido será derivado na sintaxe.

Costa aponta que os advérbios podem modificar predicados da sentença, a sentença inteira ou um PP:

(38) a. A Maria canta lindamente (predicado).

b. Supostamente, a Maria cantou (sentença).

c. A Maria cantou provavelmente para o patrão (PP).

A análise de Costa leva à flexibilização da proposta de Cinque (1999), já que, para o autor, esses domínios de modificação não são capazes de estabelecer uma relação um-a-um entre o elemento modificado e a interpretação do advérbio, pois num mesmo domínio de modificação, o advérbio pode obter sentidos diferentes. Com os dados abaixo, Costa demonstra tal afirmação, pois se podem analisar os advérbios destacados em comportamento sintático semelhante (adjuntos ao domínio de IP), mas com sentidos distintos:

(39) a. Francamente, eu tenho fome (orientação para o falante).

b. Honestamente, diz-me o que achas (orientação para o ouvinte).

c. Estupidamente, o João respondeu à pergunta (orientação para o sujeito).

d. Matematicamente, isso é absurdo (orientação para o domínio).

e. Provavelmente, ela é feliz (orientação para o valor de verdade).

Da mesma maneira, há advérbios que pertencem à mesma classe semântica e apresentam um comportamento sintático diferente:

(40) a. Eu já te tinha dito isso.

b. Eu, frequentemente, dizia-te isso.

Em cada sentença acima há um advérbio aspectual. No entanto, o advérbio já é um "proclisis trigger", mas o advérbio frequentemente, não o é. Para o autor, dados como esses reforçam a ideia de que o comportamento sintático e a semântica dos advérbios são, pelo menos, parcialmente independentes. 
Costa analisa também a proposta de Ernst (2002 apud Costa 2008), que propõe uma semântica lexical inerente para os advérbios. Alguns advérbios podem ter sentido inerente, enquanto outros advérbios podem ter o sentido associado à distribuição sintática. Em trabalho anterior, o autor esclarece a diferença comparando advérbios como 'ontem' e 'estupidamente'. Independentemente de seu lugar na sintaxe, 'ontem' tem um sentido inerente (algo como um dia antes da referência ou do tempo enunciado), assim, posições diferentes não afetarão a sua interpretação, e sua distribuição se dará mais livremente, como se pode ver nos dados abaixo (Costa, 2004: 719):

(41) a. O João ontem tinha estado a falar com os amigos.

b. O João tinha ontem estado a falar com os amigos.

c. O João tinha estado ontem a falar com os amigos.

d. O João tinha estado a falar ontem com os amigos.

e. O João tinha estado a falar com os amigos ontem. (Costa 2004: 719)

Um advérbio como 'estupidamente', por outro lado, sem sentido inerente, pode ter dois sentidos: uma leitura de maneira, que pode ser parafraseada como 'uma maneira estúpida', ou pode ter uma leitura orientada para o sujeito, que pode ser parafraseada como 'foi estupidez de $\mathrm{X}$ fazer $\mathrm{Y}$ '. Dessa maneira, sua distribuição é mais restrita, pois não são todas as posições que estão disponíveis para as duas leituras (Costa, 2004: 719):

Leitura de maneira:

(42) a. *O João estupidamente tinha estado a falar com os amigos.

b. O João tinha estupidamente estado a falar com os amigos.

c. O João tinha estado estupidamente a falar com os amigos.

d. O João tinha estado a falar estupidamente com os amigos.

e. O João tinha estado a falar com os amigos estupidamente.

Leitura orientada para o sujeito:

(43) a. O João estupidamente tinha estado a falar com os amigos.

b. ?? O João tinha estupidamente estado a falar com os amigos.

c. *O João tinha estado estupidamente a falar com os amigos.

d. *O João tinha estado a falar estupidamente com os amigos.

e. *O João tinha estado a falar com os amigos estupidamente. 
Segundo o autor, embora a diferença seja pequena, pois envolve somente a posição pré-auxiliar versus todas as outras potenciais posições, o contraste entre (42) e (43) demonstra que há uma diferença entre a livre distribuição de advérbios como 'ontem' e 'estupidamente'.

Baseando-se na proposta de Ernst, Costa (2008) afirma ainda que há advérbios predicativos que são, frequentemente, ambíguos entre a leitura orientada para o agente e a leitura de modo. Para ele, a posição mais alta engatilha a leitura orientada para o agente, enquanto a posição mais baixa engatilha a posição orientada para o modo. Mas há advérbios predicativos que não são ambíguos. Vejamos os dados abaixo que ilustram a diferença entre advérbios ambíguos (como com estupidamente, em (42) e (43)), e o comportamento de advérbios orientados para o agente, que não são ambíguos entre essa leitura e a leitura de modo (propositadamente) nos dados abaixo:

Leitura orientada para o agente (advérbios não-ambíguos)

(44) a. O João propositadamente tinha estado a falar com os amigos.

b. O João tinha propositadamente estado a falar com os amigos.

c. O João tinha estado propositadamente a falar com os amigos.

d. O João tinha estado a falar propositadamente com os amigos.

e. O João tinha estado a falar com os amigos propositadamente.

Com os dados acima, o autor demonstra que advérbios que manifestam significação ambígua, como estupidamente, têm distribuição rígida, sendo a leitura predicativa restrita à realização como advérbio alto; enquanto advérbios não-ambíguos, como propositadamente e ontem, que têm significação lexical inerente, admitem diferentes posicionamentos sintáticos.

Costa faz uma importante observação à proposta de Ernst, pois afirma que advérbios com o mesmo significado podem se distribuir de forma diferente:

(45) a. *O Pedro bem cozinhou.

b. O Pedro cozinhou bem.

A análise dos dados em (45) pode conduzir a um abrandamento do mapeamento sintático-semântico proposto por Ernst. Costa propõe que esse mapeamento é operatório apenas quando o sentido do advérbio é suficientemente transparente. No caso de (45), há um 
advérbio com leitura de modo inerente, e isso não é suficiente para licenciar sua livre distribuição.

Vimos, no capítulo 1, que Câmara Júnior (1979) aponta a existência de advérbios que podem acumular a função de conectivo. Costa (2008) desenvolve também essa questão. Consideremos os dados abaixo analisados pelo autor:

(46) a. A Maria está grávida. Consequentemente, tem enjoos matinais.

b. Assim, chegamos ao fim desta viagem.

c. Compreendo que estejas aborrecido. Agora, fazer greve de fome não é justificável.

d. Estas são as minhas conclusões. Bem, não tenho mais nada a dizer.

As palavras destacadas nos dados acima possuem um comportamento específico, mas o autor assume que esse comportamento como conectivo não tem implicações para a classificação dessas palavras como advérbios, o que está de acordo com a proposta de Câmara Jr. (1979). Costa afirma que palavras como porém, todavia e contudo (tradicionalmente classificadas como conjunções) não se comportam como a conjunção mas por duas razões: primeiro, seus lugares são diferentes. Todas elas podem aparecer na posição inicial da sentença, porém apenas a conjunção mas não pode aparecer entre o sujeito e o verbo, posição disponível para os advérbios:

(47) a. Quase todas as aves voam, \{mas/ porém/ todavia/ contudo $\}$ os pinguins não voam.

b. Quase todas as aves voam. Os pinguins, \{porém/ todavia/ contudo/*mas \} não voam.

Segundo, a conjunção e o advérbio conectivo podem co-ocorrer na mesma sentença, e não estão em distribuição complementar:

(48) Quase todas as aves voam, mas os pinguins, porém, não voam.

Os dados acima, segundo o autor, demonstram que, embora os advérbios conectivos e as conjunções possam ter a mesma função no discurso, pertencem a classes diferentes. Os 
advérbios conectivos podem aparecer como modificadores do predicado, obtendo uma leitura típica de tempo, lugar ou modo:

(49) a. Assim, conseguimos abrir a porta.

b. Conseguimos abrir a porta assim.

c. Ter enxaqueca é ruim. Agora, ficar em casa é bom.

d. Fico em casa agora.

Para o autor, o sentido e a distribuição desses advérbios seguem o padrão geral: advérbios de VP ocorrem em posição baixa e funcionam como modificadores do predicado; advérbios sentenciais tendem a aparecer em posições mais altas e funcionam como modificadores da oração; e os advérbios conectivos aparecem nas mesmas posições dos advérbios sentenciais, mas não demonstram um papel de modificação.

\subsection{Advérbios como especificadores de núcleos funcionais (Cinque, 1999) e uma proposta de análise para o advérbio "lá" no português brasileiro (Pereira, 2011)}

Sabemos que no PB o advérbio "lá" pode realizar-se de diferentes maneiras. Segundo Pereira (2011), esse advérbio pode indicar dêixis locativa, além de indicar negação, imperativo, questão retórica, entre outros. A autora parte do pressuposto de Cinque (1999) de que advérbios são especificadores de projeções funcionais e, por isso, teriam uma ordem rígida determinada pela GU e checariam traços de um núcleo de categorias funcionais como, por exemplo, negação, modo e especificidade. A autora também se baseia na distinção feita por Cinque (1999) entre advérbios propriamente ditos, que ocupam posição rígida na oração, como já, sempre, frequentemente, etc., que checam traços dos núcleos de categorias funcionais na posição de especificador; e advérbios circunstanciais, que são indicadores de circunstância (lugar, tempo etc.), ocupam a posição de adjunto, são mais flexíveis e, por isso, não podem ser analisados como especificadores de categorias funcionais (são realizados tipicamente por itens que não são advérbios, mas NPs nus ou PPs, como amanhã, na cozinha, por três horas). Partindo dessa distinção, Pereira (2011) contrasta basicamente dois grupos de realizações de "lá": o grupo em que "lá" seria um item circunstancial locativo, com relativa mobilidade na sentença:

(50) Vi o menino lá (no refeitório) 
e o grupo em que "lá" conteria propriedades não locativas, apresentando ordenação rígida na estrutura da sentença, pertencendo à classe dos advérbios propriamente ditos, conforme ilustrarão os dados nas seções seguintes.

\subsection{1 "Lá" em questões retóricas e em sentenças imperativas (em Spec, FocusP)}

Pereira (2011) propõe que "lá" em questões retóricas e em sentenças imperativas faz parte da cartografia do $\mathrm{CP}$, ocupando a posição de especificador em projeções funcionais.

(51) O João (lá) comprou (lá) um carro?

Uma questão retórica, segundo a autora, caracteriza-se por não ser feita para obter informações do ouvinte e por ter a capacidade de inverter a polaridade da sentença, assim, uma questão retórica positiva tem a força ilocucionária de uma asserção negativa e vice-versa, como se pode ver na paráfrase de (52a) por uma sentença negativa em (52b):

(52) a. O João (lá) comprou (lá) um carro?

b. O João não comprou um carro.

Em estruturas como (51), "lá" pode tanto ser pré-verbal quanto pós-verbal, além de poder ser omitido. Por poder ocupar a posição pré-verbal, Pereira (2011) propõe que, nesse caso, "lá" está situado acima da categoria que aloja o verbo (acima de IP), provavelmente na periferia esquerda, pois "lá" veicula informações condizentes com o domínio de CP: informações de caráter enfático e discursivo. No caso de "lá" ocupar a posição pós-verbal, a posição seria justificada pelo alçamento do verbo para uma posição mais alta que aquela em que "lá" está. Pereira (2011), então, postula que "lá" é inserido por merge no domínio de CP, possivelmente em Spec, FocusP, pois recebe foco entonacional, é incompatível com itens focalizados (53b) e permite recursão de tópico acima e abaixo dele:

(53) a. TUDO, o João comprou. Não faltou nada.

b. *TUDO o João lá comprou?

Em particular, a autora nota que as interrogativas retóricas permitem que seus constituintes sejam ordenados de várias maneiras: 
(54) a. O João lá comprou um carro? Foi o pai dele.

b. Lá um carro o João comprou? Aquilo é uma lata velha.

c. Lá o João comprou um carro? Foi o pai dele.

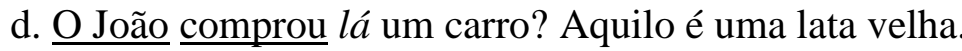

e. (?) Lá comprou carro o João? Ele pediu emprestado ao pai dele.

Apesar das possibilidades de ordenação, Pereira (2011) observa que "lá" continua na posição de foco, enquanto "o João" (54a), "um carro" (54b), “o João" (54c), e "comprou” (54d) movem-se para posições de tópico mais altas ou mais baixas que a posição ocupada por “lá". Vejamos as derivações propostas por Pereira (2011: 61-62):

(54) a. O João lá comprou um carro? Foi o pai dele.

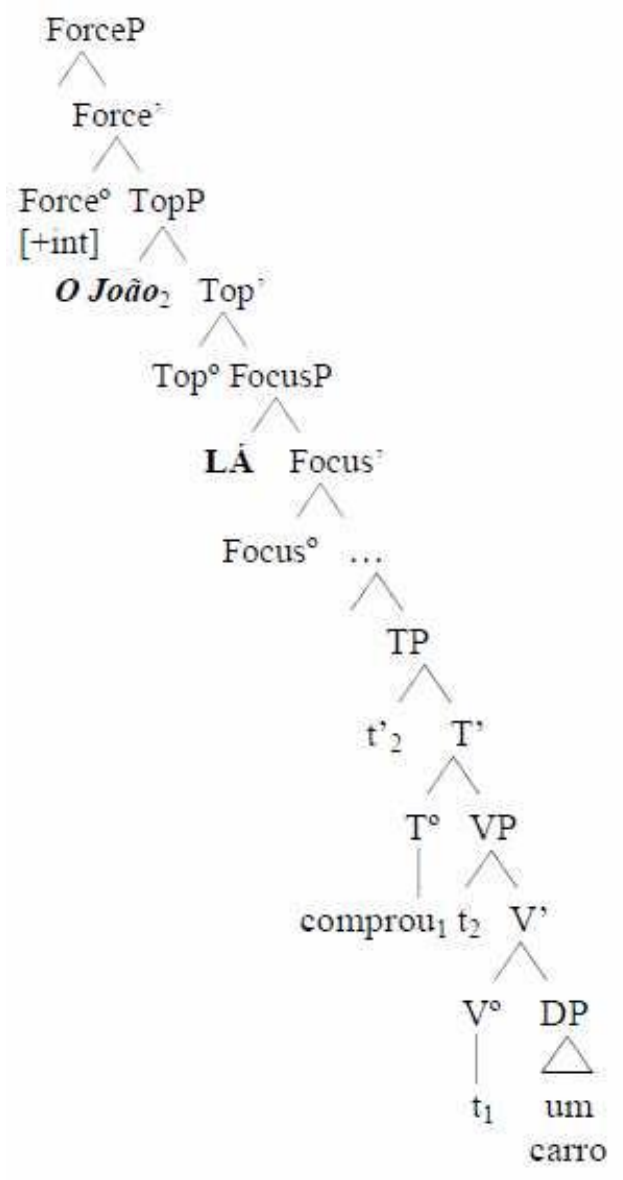

(54) b. Lá um carro o João comprou? Aquilo é uma lata velha.

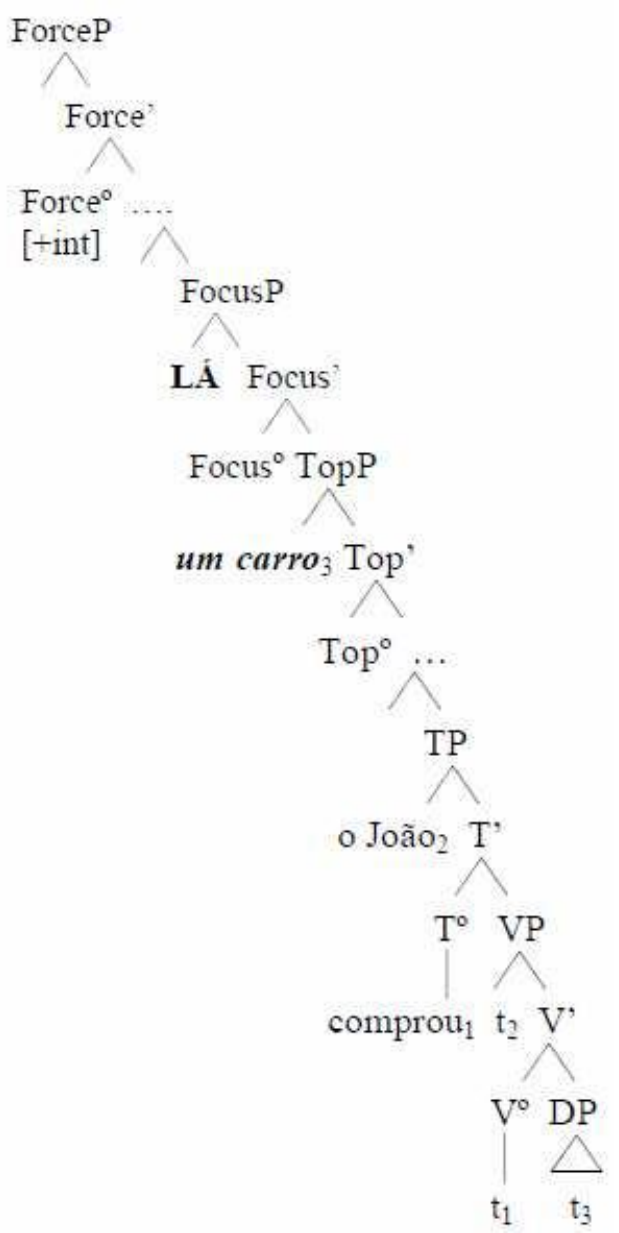


(54) c. Lá o João comprou um carro? Foi o pai dele.

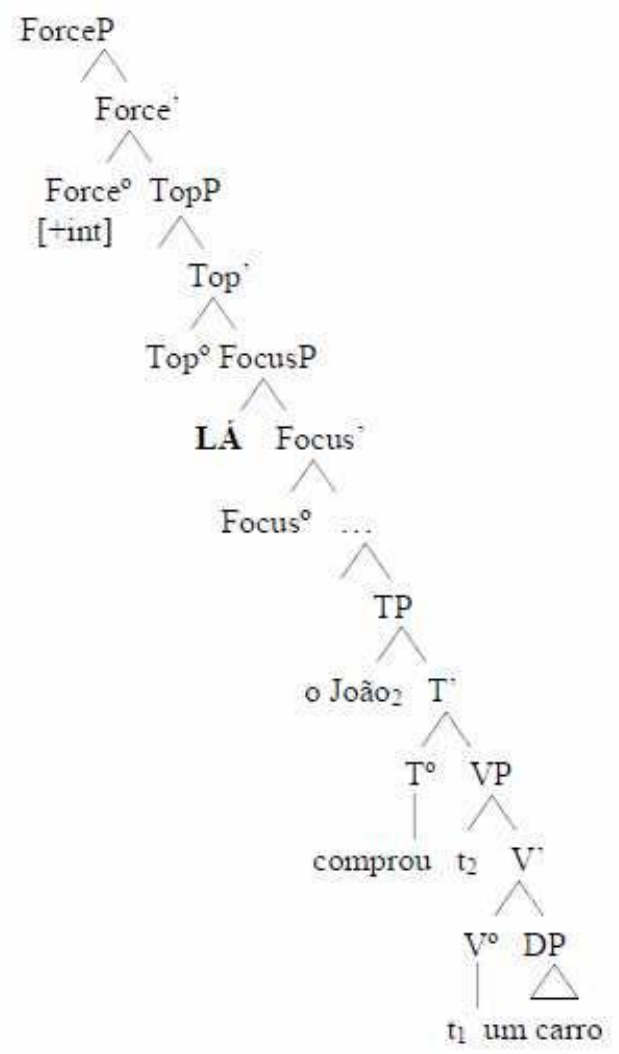

(54) d. O João comprou lá um carro?

Aquilo é uma lata velha.

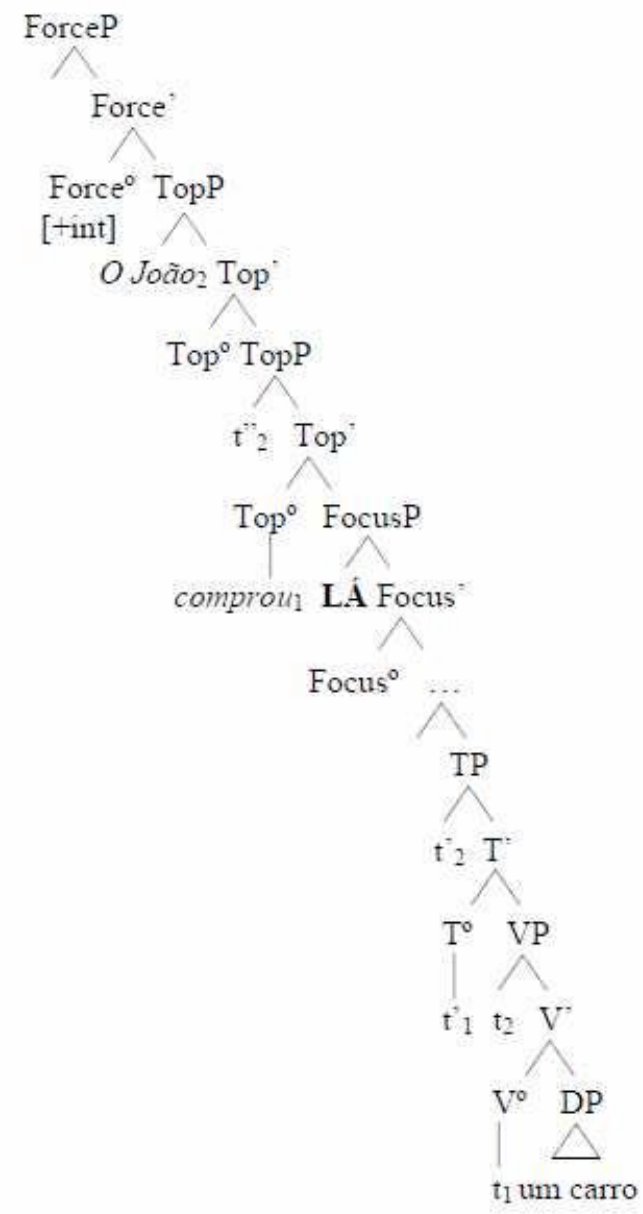

A autora ressalta que "lá" nessas estruturas não é um marcador de negação, pois pode ser elidido em questões retóricas de polaridade positiva e, ainda assim, a sentença continuar sendo entendida como negação:

(55) a. O João (lá) comprou um carro?

b. Eu sou (lá) mulher de levar desaforo para casa?

c. Vê (lá) se eu vou aceitar meu marido mandar em mim?

Dessa maneira, a interpretação de negação em (55) se deve à inversão de polaridade causada pela força ilocucionária das questões retóricas, não pela presença de "lá".

Para "lá" em sentenças imperativas, como (56), Pereira (2011) propõe que também é inserido por merge em Spec, FocusP no domínio do CP. 
(56) Calma lá! Você não pode me acusar assim.

Assim, "lá" em sentenças imperativas ocuparia a mesma posição de "lá" em questões retóricas, porém, nas imperativas o verbo alça para Force e "lá" fica sempre na posição pósverbal (56), enquanto em questões retóricas o verbo não pode alçar para ForceP, mas pode, opcionalmente, alçar para uma posição TopP e, por isso, "lá" pode aparecer antes ou depois do verbo (cf.51).

(57) *Lá calma!

Nos dados abaixo, a autora verifica que "lá" é compatível com "aqui" e intercambiável com "aí", o que corrobora para o esvaziamento de seu valor locativo nesses contextos:

(58) a. Raciocina lá comigo aqui nessa conta.

b. Calma aí! Você não pode me acusar assim.

Dessa maneira, a autora propõe que "lá" é inserido em Spec, FocusP e marca alguma ênfase tanto nas questões retóricas quanto nas sentenças imperativas, mas as estruturas são diferentes, uma vez que, nas imperativas há o alçamento do verbo para Force, mas isso não ocorre nas questões retóricas. Além disso, nas questões retóricas Force comporta traços [+Interrogativa], nas imperativas, comporta traços [+Imperativa]. Essa possibilidade de atribuir a mesma posição para "lá" nesses dois contextos é justificada por ser impossível a concomitância de imperativa e questão retórica na mesma sentença. Assim, "lá" ocorre na mesma posição nesses dois contextos, mas em construções distintas, conforme a autora ilustra na seguinte derivação (Pereira, 2011: 69): 
(59) Calma lá!

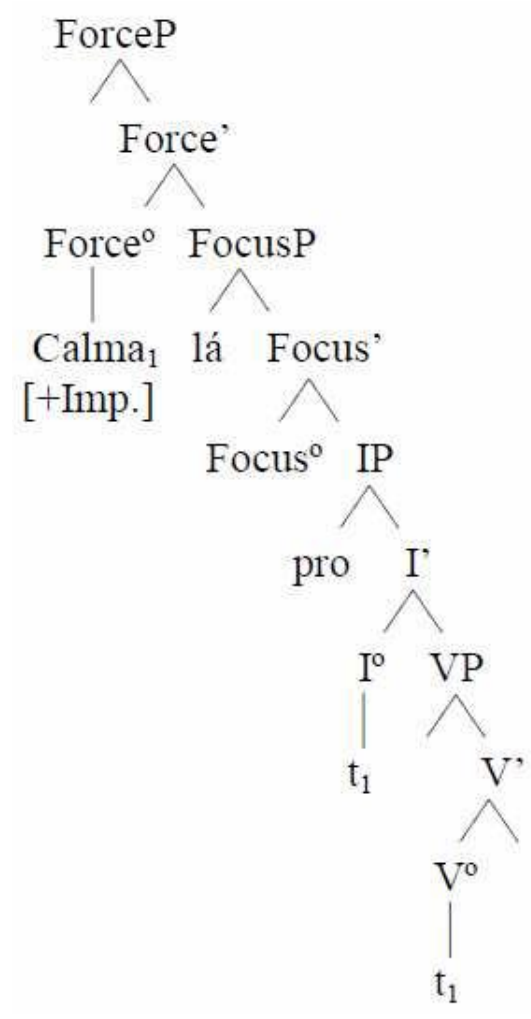

\subsection{2 "Lá” em construções inacusativas e em construções existenciais (em Spec, TopP)}

Pereira (2011) propõe que para sentenças com construções inacusativas (60a) e com construções existenciais (60b), "lá” é inserido por merge em Spec, TopP.

(60) a. Lá vem a Maria.

b. Lá tinha um trem lá.

A autora sustenta que ' $l a ́$ ' veicula informação dada, pois não são sentenças construídas para informar a localização de algo, por isso, as sentenças em $(60 a, b)$ respondem a questões concentradas no evento (61) e (62), mas não respondem a questões concentradas na informação de localização das entidades (63) e (64):

(61) A: O que está acontecendo?

B: Lá vem a Maria.

(62) A: O que tinha lá?

B: Lá tinha um trem lá. 
(63) A: De onde está vindo a Maria?

B: *Lá vem a Maria (resposta inadequada).

B': De lá (resposta adequada).

(64) A: Onde tinha um trem?

B: *Lá tinha um trem lá (resposta inadequada).

B’: Lá (resposta adequada).

Pereira (2011) demonstra ainda que é possível a recursão de tópicos para essas estruturas, pois o DP que, inicialmente, está localizado na posição pós-verbal, pode ser alçado para o domínio do CP para uma posição mais alta que aquela em que "lá" está. Assim, esse DP passa pela posição de Spec, IP até alcançar a posição de Spec, TopP, o que não poderia acontecer se "lá" estivesse em Spec, IP:

(65) A Maria lá em vem ${ }^{30}$.
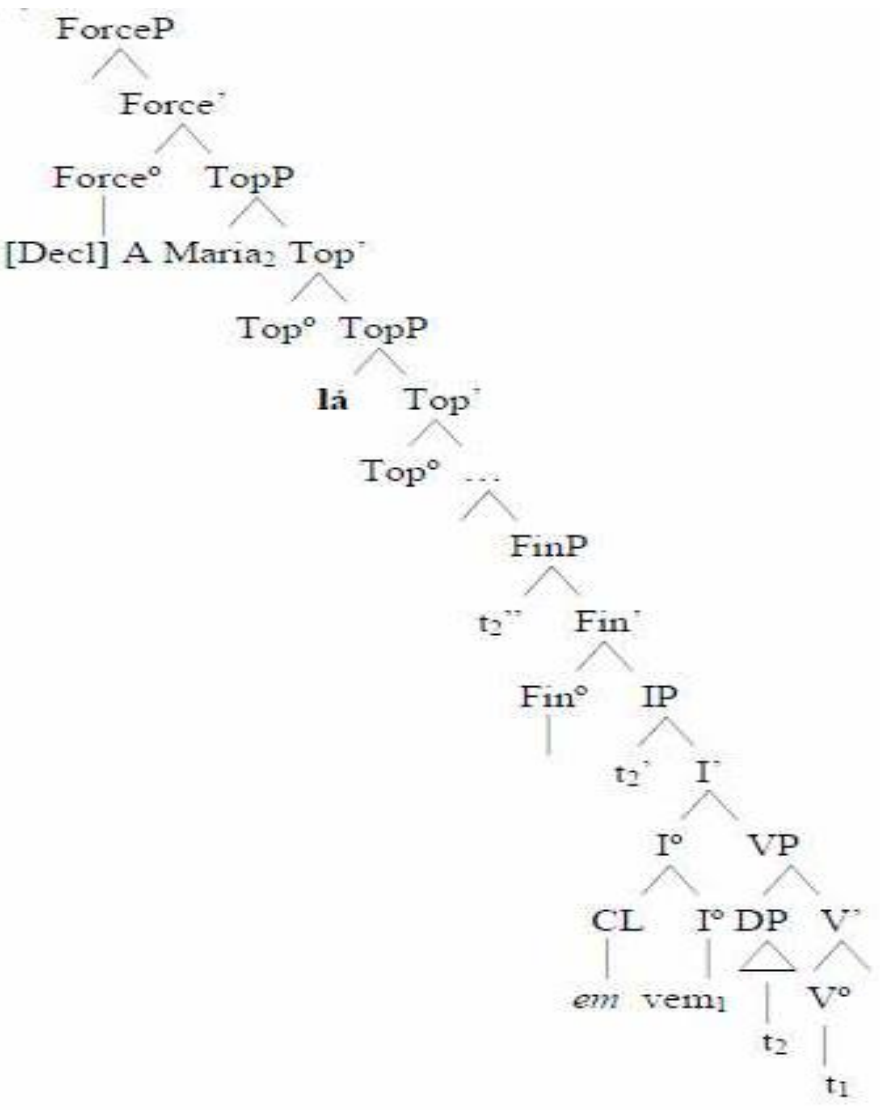

\footnotetext{
${ }^{30}$ A presença de em é uma marca dialetal, analisada pela autora como um clítico realizado na projeção de IP. Entendemos que a questão colocada pela autora é o fato de que o DP Maria que está em posição pós-verbal em 'Lá vem a Maria' pode ser alçado para o domínio de CP, passando pela posição de SpecIP.
} 
Dessa maneira, Pereira (2011) conclui que veicular informação dada, ocupar a posição inicial e poder ser precedido por um DP topicalizado são características que sugerem que "lá" pode ser analisado como tópico no $\mathrm{PB}$, pois sua posição pré-verbal não se justifica pela necessidade de checagem de traços EPP, mas por uma demanda discursiva que é codificada na periferia esquerda. O Spec, IP é realizado por uma categoria pro, enquanto o DP pósverbal está situado em Spec, VP (Pereira, 2011: 85-86):

(60) a. Lá vem a Maria.

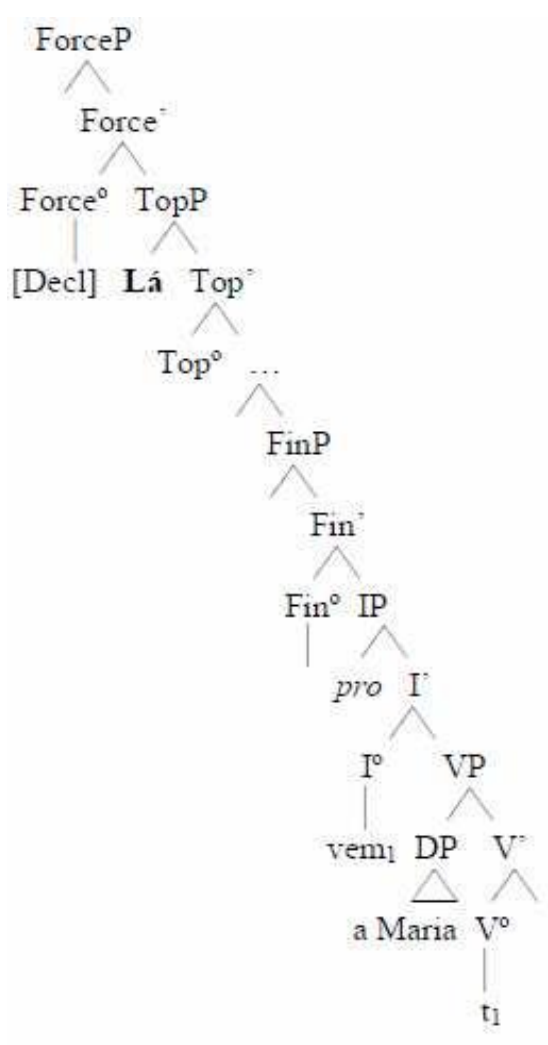

(60) b. Lá tinha um trem lá.

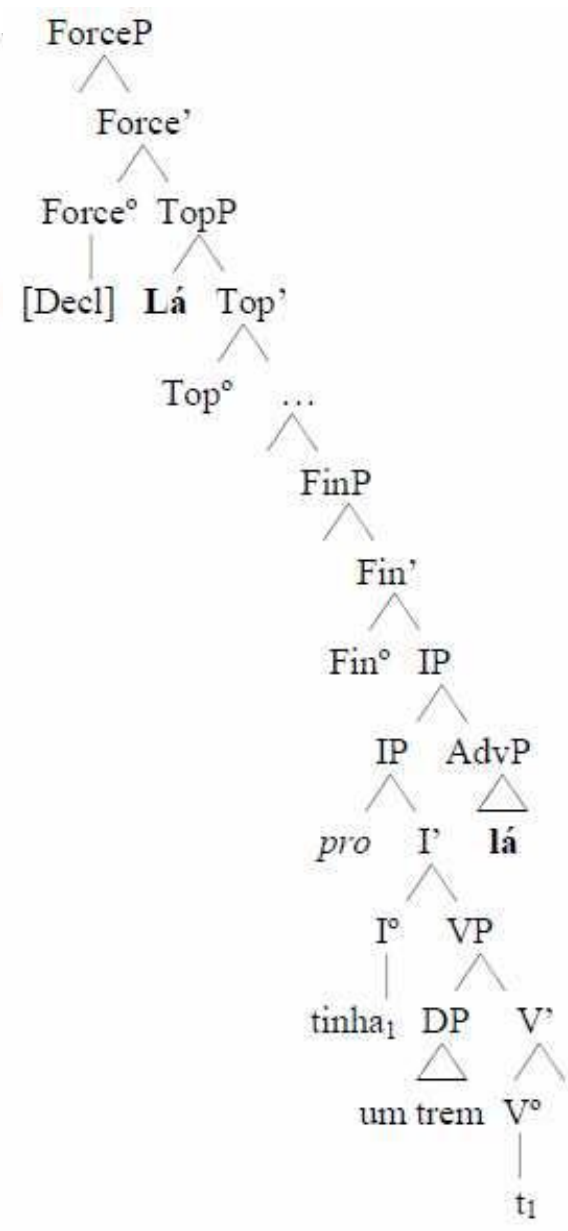

\subsection{Considerações parciais}

Neste capítulo, fizemos uma retomada dos estudos sobre a distribuição dos advérbios na estrutura oracional, recorrendo às análises de Jackendoff (1972) para o inglês, de Cinque (1999) para o italiano e o francês. E, a fim de perceber até que ponto essas análises podem contribuir para a caracterização dos advérbios no português, buscamos os estudos de Gonzaga (1997) e Pereira (2011). 
Em sua análise, Jackendoff (1972) assume uma abordagem que alia a informação de cada advérbio e as características sintáticas das estruturas onde ocorre. O autor propõe três posições básicas para o advérbio: posição inicial, posição final sem pausa e posição auxiliar (entre o sujeito e o verbo principal). Dessas três posições, derivam-se seis classes: 1) advérbios que podem ocupar as três posições com mudança de sentido; 2) advérbios que ocupam as três posições sem mudança de sentido; 3) advérbios que ocorrem somente nas posições inicial e auxiliar; 4) advérbios que ocorrem somente nas posições auxiliar e final; 5) advérbios que ocorrem somente na posição final; e 6) advérbios que ocorrem somente na posição auxiliar. Recorrendo ao estudo de Gonzaga para testar as hipóteses de Jackendoff para o português, notamos que também temos as três posições básicas: inicial, final e auxiliar (entre o sujeito e o verbo principal). No entanto, em PB, temos uma posição a mais, pois advérbios podem ocupar também a posição entre o verbo e seu complemento interno em posição de objeto direto. Além disso, as posições inicial e final podem vir com ou sem pausa no PB; a pausa pode indicar a opinião do locutor e a ausência de pausa pode indicar que o advérbio refere-se à oração, conforme aponta Bomfim (1988). Em PB, temos advérbios que podem ocupar as três posições com mudança de sentido, no entanto, não necessariamente advérbios com o sufixo -mente, como no inglês.

Na análise de Cinque (1999) para advérbios do italiano e do francês, o autor faz a distinção entre advérbios de VP e advérbios sentenciais, demonstrando que possuem uma ordem relativa fixa nessas línguas. O autor aponta também os advérbios circunstanciais, que se comportam de maneira distinta, pois podem se realizar como NPs ou como PPs, podem mudar de posição dentro do VP, e podem aparecer na posição pré-VP para ocupar a posição de tópico. Costa (2008), com base em estudos prévios de Ernst (1984, 2002), examina a proposta de Cinque (1999), observando que, além do domínio de aplicação pelo qual se distinguem os advérbios sentenciais e modificadores de VP, fatores adicionais devem ser considerados, como o significado lexical do advérbio (inerente ou não inerente), que pode estar associado a maior ou menor flexibilidade sintática.

Vimos que o estudo de Costa (2008), que se baseia em Ernst (1984; 2002), demonstra ser necessário flexibilizar a proposta de Cinque (1999), a fim de contemplar os casos em que os domínios de modificação não são capazes de estabelecer uma relação um-a-um entre o elemento modificado e a interpretação do advérbio, já que, num mesmo domínio de modificação, o advérbio pode ter sentidos distintos. Deixamos em aberto o debate quanto a se a distribuição é determinada pela estrutura sintática (Cinque 1999) ou pelas propriedades semânticas das bases lexicais e pelas relações de escopo (Ernst 1984; 2002/ Costa 2008), 
tendo em vista que neste ponto essa discussão não tem implicações para o reconhecimento de que tais elementos constituem a categoria mais abrangente dos 'advérbios'. Além disso, no capítulo a seguir, vamos nos deter na análise das construções em que o advérbio (locativo) ocorre, por hipótese, na posição de sujeito. Conforme mencionado nesta seção, os elementos desse subgrupo são realizados como advérbios de VP, não estando sujeitos às restrições de escopo encontradas nos demais casos. Além disso, por sua denotação locativa, serão analisados como categorias com índice referencial, nos termos de Baker (2004), uma característica que os identifica com os Nomes e com a série pronominal da língua, conforme proposto por Bomfim (1988). Fechamos a análise de Costa (2008) com a discussão sobre advérbios como marcadores conectivos, já apontados por Câmara Jr. (1979). Delineando as propriedades sintáticas dos advérbios em contraste com a conjunção canônica 'mas', Costa (2008) chega à conclusão de que embora advérbios conectivos e conjunções possam desempenhar a mesma função, pertencem a classes diferentes; e os advérbios conectivos seguem o padrão geral dos advérbios sentenciais, mas não demonstram um papel de modificação.

Por último, ilustramos a aplicação da proposta cartográfica de Cinque (1999) ao PB a partir do estudo de Pereira (2011). A autora parte do pressuposto de Cinque (1999) de que advérbios são especificadores de projeções funcionais e, por isso, teriam uma ordem rígida determinada pela GU e checariam traços de um núcleo de categorias funcionais como, por exemplo, negação, modo e especificidade. Assim, a proposta é de que, por exemplo, "lá" em questões retóricas e em sentenças imperativas faz parte da cartografia do CP, mais especificamente, em Spec, FocusP. Para construções inacusativas e existenciais, a autora propõe que "lá" está em Spec, TopP.

Enfim, se perguntarmos qual é o poder da sintaxe na determinação da classe e do significado dos advérbios temos então, segundo Costa (2008), duas perspectivas opostas: no trabalho de Cinque (1999), temos a hipótese de relação um-a-um entre o significado e o mapeamento sintático do advérbio; na perspectiva Costa (2008), que baseia-se na proposta de Ernst (1984, 2002), a relação entre o significado e a posição do advérbio é bem mais restrita, pois, no caso dos advérbios com significado inerente, a sua posição é condicionada pela sua semântica lexical. Para a presente discussão, interessa-nos essencialmente a distinção do domínio sintático de aplicação dos advérbios, entre modificadores sentenciais e modificadores do predicado (VP), o que nos permite, por um lado, identificar o advérbio como classe independente, em relação a outras classes de palavras, e, por outro, reter as análises de Cinque (1999) e Costa (2008), sem que se faça necessário discutir, neste trabalho, as implicações 
teóricas da relação entre a significação inerente dos advérbios e a distribuição hierárquica (rígida) dos núcleos funcionais que os hospedam.

No capítulo 4, retomaremos a questão em relação à ocorrência de advérbios em posições mais baixas. Conforme mencionado anteriormente, no grupo de advérbios modificadores de VP, Cinque destaca os advérbios circunstanciais, que se distinguem dos demais advérbios deste domínio. Antecipamos que será feita uma relação entre a mobilidade do advérbio e a sua ocorrência na estrutura do VP (como modificador do VP). Aprofundaremos a discussão acerca das propriedades formais de advérbios de VP, em particular, dos denominados locativos, que possuem uma característica sintática específica: parecem ocupar a posição de sujeito no PB. Como será demonstrado, existem restrições quanto ao tipo de advérbios que ocorrem nessa posição e quanto aos traços formais relevantes. Iniciaremos o capítulo com considerações gerais sobre a tendência de preenchimento dessa posição em nossa língua. Para abordar a questão, recorreremos ao estudo de Larson (1985), que examina sintagmas nominais com habilidade de funcionar como modificadores adverbiais. Esse estudo se faz relevante para esta discussão, na medida em que constatamos que advérbios locativos podem ser intercambiáveis com NPs e PPs (conforme também foi apontado por Cinque (1999)), o que sugere que podem compartilhar propriedades que licenciam determinadas posições. Discutiremos a hipótese de realizar advérbios, NPs e PPs locativos na posição de sujeito a partir dos estudos de Pontes (1986) e (1987), Galves (1998), Bresnan (1994), Pilati (2006), Avelar e Cyrino (2008) e (2009), Avelar (2009). Para finalizar a discussão, examinaremos possíveis propriedades formais que licenciam advérbios locativos nessa posição, aprimorando nossas reflexões anteriores, em particular, Teixeira e Salles (2013 $\mathrm{a} ; \mathrm{b})$. 


\section{CAPÍTULO 4}

\section{ADVÉRBIOS LOCATIVOS E A POSIÇÃO DE SUJEITO NO PB}

$\mathrm{Na}$ abordagem gerativa, encontra-se formulada a hipótese de haver o traço EPP (originalmente relacionado ao Princípio de Projeção Estendida), que impõe que o núcleo do predicado projete um especificador (Chomsky 1981; 1995). Há maneiras diferentes de realizar esse especificador na estrutura: por um argumento do verbo, como em (1a), ou por meio de um pronome expletivo - foneticamente realizado, como 'it', em (1b) do inglês, ou nulo, como pro, em (1c), do português:

(1) a. Mary slept.

b. It rains.

c. pro Chove

De acordo com a Teoria dos Princípios e Parâmetros (Chomsky, 1981; 1986; 1995), os dados em (1b) e (1c) ilustram o chamado Parâmetro do Sujeito Nulo, que pode ser marcado positiva ou negativamente nas línguas naturais. Enquanto em (1b), do inglês, o parâmetro é marcado negativamente, em (1c), do português, a ocorrência de pro é associada à marcação positiva do parâmetro do sujeito nulo.

Os estudos funcionalistas de Pontes $(1986,1987)$ e os estudos gerativistas de Galves (1996, 1998) demonstram a existência de uma mudança gramatical na língua, que estaria associada a uma nova gramática na qual há um enfraquecimento no paradigma dos morfemas de flexão verbal, que resultaria numa tendência de maior preenchimento da posição de sujeito. Enquanto a necessidade de realizar foneticamente o sujeito em outras línguas foi satisfeita com o desenvolvimento do expletivo, como $i l$, no francês, pelo qual o sujeito não referencial aparece foneticamente realizado, no PB, a estratégia é diferente, já que elementos não canônicos parecem preencher essa posição.

No capítulo 2, apontamos a possibilidade de advérbios locativos ocuparem a posição de sujeito (Bomfim, 1988). No capítulo 3, vimos que esse tipo de advérbio é interno ao VP e difere-se dos demais por poder se realizar como PPs ou como NPs (conforme proposta de Cinque, 1999).

Neste capítulo, discutiremos, então, a relação entre advérbios locativos e seus NPs, PPs locativos correspondentes, examinando suas propriedades sintáticas e a hipótese de 
ocuparem tal posição. Baseando-nos nessa hipótese, formulamos a terceira questão desta tese, repetida abaixo:

Questão 3: Os advérbios, nesses casos, ocupam a posição de sujeito no $\mathrm{PB}$ ou estão na periferia da oração, por deslocamento à esquerda? Em cada caso, quais são os fatores sintáticos e semânticos responsáveis pelo licenciamento de advérbios? Que fatores restringem a presença de outros advérbios nessa posição?

Para discutirmos essa questão, e considerando que advérbios circunstanciais podem realizar-se como PPs ou NPs, recorremos aos estudos de Bresnan (1994), Pilati (2006), Avelar e Cyrino (2008a, b; e 2009) e Avelar (2009) que examinam a possibilidade de PPs locativos ocuparem a posição de sujeito. Na seção seguinte, traremos estudos que discutem a hipótese do NP locativo nessa posição, como Larson (1985), Pontes (1986; 1987), Galves (1998), Munhoz e Naves (2010) e Munhoz (2011). Esses estudos se tornam relevantes para este trabalho na medida em que nos auxiliam a refletir sobre a possibilidade de que sintagmas que compartilham propriedades distribucionais poderão compartilhar propriedades categoriais:

(2) a. Nessa casa bate sol.

b. Essa casa bate sol.

c. Aqui bate sol.

Em seguida, traremos a nossa proposta, refinando nossos estudos anteriores (Teixeira e Salles, 2013a, b) sobre o advérbio na posição de sujeito.

\subsection{A Inversão Locativa e a posição de sujeito: Bresnan (1994)}

Numa análise léxico-funcional, Bresnan (1994) investiga estruturas do inglês e do chichew $^{31} \mathrm{a}^{31}$ (uma das línguas Bantu da África centro-oriental, tipologicamente distante do inglês), que envolvem um locativo anteposto ao verbo e um sujeito posposto. Além disso, a inversão das posições não causa alterações na estrutura semântica do verbo. Tais estruturas, ilustradas pelos dados abaixo (Bresnan, 1994:75) são conhecidas como Inversão Locativa (IL):

\footnotetext{
${ }^{31}$ Agradecemos ao professor Fábio Bonfim Duarte (UFMG) que, em ocasião do evento Portuguese Linguistics in the United States (PLUS) 2013, na Universidade da Georgia, contribuiu com o nosso trabalho, discutindo os dados de línguas Bantu, que possuem advérbios com marcadores nominais na posição de sujeito.
} 
(3) a. A lamp was in the corner.

b. In the corner was a lamp.

'No canto estava um abajur'

(4) a. My friend Rose was sitting among the guests.

b. Among the guests was sitting my friend Rose.

'Entre os convidados estava sentada minha amiga Rose'.

(5) a. The tax collector came back to the village.

b. Back to the village came the tax collector.

'De volta à vila veio o coletor de taxas'.

Segundo a autora, essa estrutura é associada à estrutura argumental tema-locativo. O papel semântico tema alterna, universalmente, entre as posições de objeto e de sujeito. Tanto em inglês quanto em chicheŵa, o tema é o objeto sintático de um verbo transitivo ativo e o sujeito sintático de um verbo transitivo passivo. Em ambas as línguas, verbos intransitivos como be, sit e come têm o tema como sujeito, mas permitem que ele apareça na posição pósverbal (objeto) na inversão locativa, além de selecionarem locativos como argumentos. A autora demonstra que com verbos transitivos essa estrutura não é possível, o que torna a intransitividade verbal uma condição para a IL (Bresnan,1994: 77):

(6) a. My friend Rose seated my mother among the guests of honor. 'Minha amiga Rose sentou minha mãe entre os convidados de honra'. b. *Among the guests of honor seated my mother my friend Rose. c. *Among the guests of honor seated my friend Rose my mother.

(7) a. A lucky hiker can find the reclusive lyrebird in this rainforest. 'Um caminhante sortudo pode encontrar um pássaro recluso nesta floresta'. b. *In this rainforest can find the reclusive lyrebird a lucky hicker. c. *In this rainforest can find a lucky hiker the reclusive lyrebird. 
Também no chicheŵa, verbos intransitivos como -li 'be', khala 'sit' e bwera 'come' permitem a IL, enquanto verbos transitivos como peza 'find', thamangitsa 'chase' e tumiza 'send' não a permitem.

No entanto, a IL é possível com alguns verbos transitivos passivizados no inglês ${ }^{32}$ (Bresnan, 1994: 78):

(8) a. My mother was seated among the guests of honor.

b. Among the guests of honor was seated my mother.

'Entre os convidados de honra foi sentada minha mãe'.

(9) a. The reclusive lyrebird can be found in this rainforest.

b. In this rainforest can be found the reclusive lyrebird.

'O pássaro recluso pode ser encontrado nesta floresta'.

A IL praticamente só acontece com verbos intransitivos. Mas, nem todos os verbos intransitivos permitem a IL ${ }^{33}$ (Bresnan, 1994: 78):

(10) a. Among the guests was sitting my friend Rose.

'Entre os convidados estava sentada minha amiga Rose.

b. *Among the guests was knitting my friend Rose.

'Entre os convidados estava tricotando minha amiga Rose'.

(11) a. Onto the ground had fallen a few leaves.

'No chão tinham caído poucas folhas'.

b. *Onto the ground had spit a few sailors.

'No chão tinham cuspido poucos marinheiros'.

(12) a. Into the hole jumped the rabbit.

'No buraco pulou o coelho'.

b. *Into the hole excreted the rabbit.

'No buraco excretou o coelho'.

\footnotetext{
${ }^{32}$ E também no chicheŵa.

${ }^{33}$ A autora aponta que o mesmo fenômeno acontece no chicheŵa.
} 
(13) a. Toward me lurched a drunk.

'Em minha direção cambaleava um bêbado'.

b. *Toward me looked a drunk.

'Em minha direção olhava um bêbado'.

(14) a. On the corner was standing a woman.

'Na esquina estava em pé uma mulher'.

b. *On the corner was drinking a woman.

'Na esquina estava bebendo uma mulher'.

Segundo a autora, a IL pode ocorrer nos casos em que o sujeito pode ser interpretado como o tema da localização, da mudança de localização ou da direção expressa pelo locativo. Assim, os verbos intransitivos be, sit e come satisfazem a característica de terem um sujeito tema do locativo. Já os verbos transitivos seat, find e place em vez de predicar a localização de seus sujeitos, predicam a localização de seus objetos. Entretanto, quando esses mesmos verbos transitivos são passivizados, o agente é sumprimido, e o sujeito recebe o papel semântico de tema, possibilitando a ocorrência da IL. No que diz respeito à impossibilidade de IL com verbos como to knit, to spit, to excrete, to look e to drink, a autora observa que não predicam a localização de seus sujeitos. Se um PP locativo ocorre com esses verbos, ele é um adjunto descrevendo a localização do evento ou predica um argumento (possivelmente implícito) não-sujeito.

Então, as evidências demonstram que os verbos em inglês permitem a IL se eles predicam a localização ou direção de seus sujeitos. A mesma hipótese, segundo a autora, se verifica no chicheŵa.

Segundo Bresnan (1994), o chicheŵa traz evidências de que o locativo é o sujeito gramatical na inversão locativa. Da variedade de evidências discutidas em trabalho anterior ${ }^{34}$, a autora aponta três que, comumente, levam à validação do sujeito gramatical nas línguas: a concordância entre o sujeito e o verbo, o controle do sujeito e o alçamento do sujeito.

A autora explica que os verbos finitos no chicheŵa têm uma obrigatoriedade de um "prefixo sujeito", que concorda em gênero, número e pessoa (isto é, classe nome) com o

\footnotetext{
${ }^{34}$ BRESNAN, J. e KANERVA, J.M. (1989). Locative inversion in Chichewa: A case study of factorization in grammar. Linguistic Inquiry 20. 1-50 [Reprinted in Stowell e Wehrli, 53-101].
} 
sujeito gramatical. Nos casos de inversão locativa, a concordância com o locativo é obrigatória, como demonstram os dados abaixo (Bresnan, 1994: 93) ${ }^{35}$ :
a. Pa m-sikă-pa
pá bádw-a
nkhonya.

\section{3-market-16.this 16.SUBJ.IM.FUT-be.born-FV 10.fist}

'At this Market a fight is going to break out.'
b. $\mathrm{Ku}$ mu-dzi
ku na-bwér-á
a-lěndo.
17 3-village
17.SUBJ-REC.PST-come-FV
2-visitor

'To the village came visitors.'
c. M nkhalăngo mw a-khal-á
mí-kângo.

\section{9.forest 18.SUBJ-PRF-remain-FV 4-lion}
'In the forest have remained lions.'

A falta de qualquer um dos três prefixos nos exemplos acima tornaria as sentenças agramaticais. Esses prefixos são indistinguíveis dos outros prefixos de concordância entre sujeito e verbo. Logo, a inversão locativa no chicheŵa satisfaz a maior das generalizações para o sujeito gramatical: o verbo finito concorda obrigatoriamente com o sujeito.

Quanto ao controle de VPs atributivos, o chicheŵa tem verbos no infinitivo que podem ser usados como um modificador atributivo de NPs, como o particípio no inglês (Bresnan, 1994: 93):

\footnotetext{
${ }^{35}$ Em relação às glosas, referimos o leitor aos esclarecimentos apresentados em Bresnan (1994:76-77): "the locative class markers 16, 17, and 18 of nouns (but not verbs and adjectives) are glossed as particles rather than prefixes in this and subsequente examples, in accordance with the results of Bresnan \& Mchombo 1993. (...). Chichewa has eighteen noun classes, which are denoted by arabic numerals in the glosses, including a class 1A; roman numerals are used for first and second person; and the following abbreviations are also used: NEG= negative, $\quad \mathrm{sg}=$ singular, $\mathrm{SUBJ}=$ subject, $\mathrm{OBJ}=$ object, $\mathrm{PROG}=$ progressive, $\mathrm{PRF}=$ presente perfect, REC.PST=recente past, IM.FUT = immediate future, PRS.HAB=presente habitual, APPL=applicative, $\mathrm{PASS}=$ passive, $\mathrm{FV}=$ final vowel, $\mathrm{POSS}=$ possessive pronoun, $\mathrm{ASC}=$ associative, and $\mathrm{INF}=$ infinitive.".
} 

a. m-sodzi [vp w-ó-ík-á nsómbá pa m-pando] vP
1-fisherman 1-ASC.INF-put-FV
10.fish 16 3-chair
'a fisherman putting fish on a chair'
b. nsómbá [vp Z-ó-ík-ídw-á
pá m-pando] $]_{\mathrm{VP}}$
10.fish 10-ASC.INF-put-PASS-FV 16 3-chair
'fish being put on a chair'

A autora observa que o papel de agente de 'putting' é atribuído para o núcleo de NP em (16a), e o papel de paciente de 'being put' é atribuído ao núcleo de NP em (16b), assim, o agente é o sujeito do verbo na forma ativa, e o paciente é o sujeito do verbo na forma passiva. Além disso, o verbo carrega um prefixo que concorda com o controlador da classe de gênero: ele concorda com 'fisherman' em (16a) e com 'fish' em (16b). Quando ocorre a inversão do verbo no VP atributivo, o papel locativo pode ser atribuído ao controlador e o prefixo adnominal apresenta concordância locativa, como em (17):

$$
\begin{gathered}
\text { m-nkhalangó [vp m-ó-khál-á mi-kângo }]_{\mathrm{VP}} \\
\text { 18-9.forest } \quad \text { 18-ASC.INF-live-FV 4-lion } \\
\text { 'in the forest where there live lions' }
\end{gathered}
$$

Assim, para a autora, esses fatos indicam que a inversão locativa satisfaz a segunda generalização gramatical sobre o sujeito no chicheŵa: o argumento controlado do VP atributivo é o sujeito.

A terceira e última generalização diz respeito ao alçamento do sujeito. No chicheŵa, com uma determinada classe de verbos de alçamento, o locativo pode ser alçado, demonstrando que é o sujeito gramatical (Bresnan, 1994: 95):

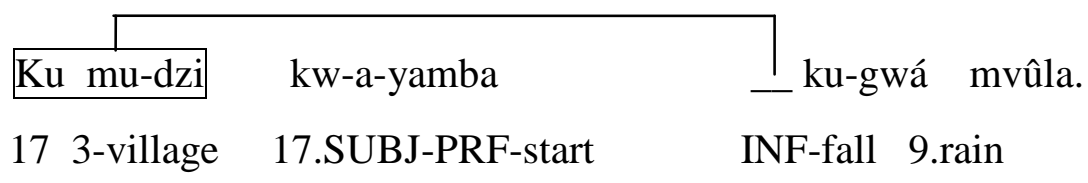

'At the village it has started to rain.'

(Lit. 'At the village has started to fall rain.'). 
Dessa maneira, Bresnan (1994) argumenta que as evidências de concordância, controle e alçamento convergem para identificar, na inversão locativa, o locativo como o sujeito gramatical em chicheŵa.

$\mathrm{Na}$ análise dos dados do inglês, a autora aponta a existência de evidências mistas para o status de sujeito da inversão locativa. Enquanto no chicheŵa, a concordância do verbo com o locativo preposto é obrigatória, no inglês o verbo concorda com o tema:

(19) a. In the swamp was/*were found a child.

b. In the swamp were/*was found two children.

'No pântano foram/*foi encontradas duas crianças'.

No entanto, o inglês possui uma classe de verbos de alçamento que permitem a IL, demonstrando as mesmas propriedades do chicheŵa (Bresnan, 1994: 96):

(20) a. Over my windowsill seems _ to have crawled an entire army of ants. 'Pela minha janela parece _ ter escalado um exército de formigas'.

b. On that hill appears __ to be located a cathedral.

'Naquele morro parece _ estar localizada uma catedral'.

c. In these villages are likely __ to be found the best examples of this cuisine.

'Nestas vilas é provável _ serem encontrados os melhores exemplos desta culinária'.

Segundo a autora, nenhum constituinte não-sujeito pode ser alçado em inglês, como podemos observar em (Bresnan, 1994: 96):

(21) a. It seems that John, you dislike.

b. *John seems you to dislike.

Parece que de John, você não gosta. 
Assim, embora haja diferenças no que diz respeito à concordância entre o inglês e o chicheŵa, para a autora, as evidências demonstram que o locativo, no inglês, é ligado à função de sujeito na IL.

\subsubsection{Inversão locativa no PB: a análise de Pilati (2006)}

O estudo de Pilati (2006) toma como ponto de partida os resultados descritivos de Pilati (2002), propondo-se analisar as propriedades sintáticas e semânticas de orações com ordem VS no PB. Retomando estudos prévios, como Nascimento (1984), Kato (2000), Figueiredo Silva (1996), observa inicialmente que as orações VS são encontradas de forma restrita no PB. Em particular, destaca que a ordem VS é licenciada com verbos inacusativos, conforme atesta Pezzati (1993), embora confirme que pode também ocorrer com verbos inergativos e transitivos.

Pilati (2006) argumenta que, embora a ordem VS no PB seja atestada com verbos inacusativos, inergativos e transitivos, devem ser analisadas como tipos de inversão locativa, tendo em vista as seguintes características sintáticas: (i) são frequentes com verbos inacusativos, particularmente de movimento (22a); (ii) manifestam, geralmente, PPs locativos ou temporais à esquerda, com interpretação dêitica (locativa ou temporal) (22b), posição que, por hipótese, pode ser nula (proLOC) e anaforicamente ligada, ocorrendo ainda na presença de elementos discursivos e operadores de foco, como só, também; (iii) apresentam restrições a verbos transitivos, ocorrendo em narrações concomitantes e em expressões idiomáticas (cf. 22c, d):

(22) a. Chegou o trem/*Avermelhou o urubu.

b. Neste hotel dormiu a Maria/ *Em hoteis dormiu a Maria.

c. Arriscou o chute Diego Tardelli.

d. Hoje tomou posse o novo ministro da Cultura.

A análise das orações do tipo (PP)VS do PB como inversões locativas apoia-se no estudo de Pinto (1997), sobre o italiano, bem como em análises prévias dessas estruturas em línguas como o chichewa e o inglês (respectivamente Bresnan \& Kanerva (1989); e Levin \& Rappaport (1995), citados pela autora, mas veja-se também Bresnan (1994), na seção 4.1, acima). Partindo da observação de Bresnan (1994) de que fatores discursivos interferem na distribuição das estruturas com inversão locativa em línguas como o chichewa (e também o inglês), Pilati (2006) demonstra que esses fatores estão presentes nas estruturas VS do PB, 
pela exigência dos dêiticos (locativos e temporais), ou de dêiticos nulos recuperados anaforicamente.

A autora observa ainda que a presença dos dêiticos (locativos e temporais) pode ser inferida em estruturas com ordem VS do PB em que o dêitico não ocorre à esquerda, mas é possível atribuir uma interpretação dêitica, como representado pelo contraste entre as sentenças $a$ e $b$, a seguir ${ }^{36}$ :

(23) a. Morreu Fellini.

Fellini acabou de morrer (Eu acabei de ouvir que Fellini morreu).

b. Fellini morreu.

Fellini morreu (há algum tempo).

Essa interpretação dêitica, relacionada ao momento da enunciação ou a um lugar específico cuja referência é compartilhada pelos interlocutores, é também encontrada nas estruturas VOS, em que ocorrem as chamadas narrativas concomitantes, como em (22).

Na análise das estruturas V(O)S no PB como casos de inversão locativa, Pilati (2006) postula que o dêitico (locativo ou temporal) encontra-se vinculado à posição sujeito, trazendo como argumento orações como as em (24) e (25), em que "o elemento dêitico manifesto controla sujeitos encaixados, comportando-se da mesma maneira que sujeitos prototípicos em posição pré-verbal":

(24) a. As crianças dormem ali porque $e_{\mathrm{i}}$ querem.

b. *Ali dormem as crianças $s_{\mathrm{i}}$ porque $e_{\mathrm{i}}$ quer.

c. $\mathrm{Ali}_{\mathrm{i}}$ dormem as crianças porque $e_{\mathrm{i}}$ é mais quente.

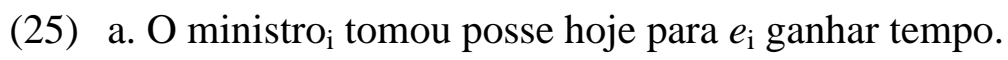

b. *Hoje tomou posse o ministro para $e_{\mathrm{i}}$ ganhar tempo.

c. Hoje $\mathrm{e}_{\mathrm{i}}$ tomou posse o ministro para $e_{\mathrm{i}}$ coincidir com a data da proclamação da República.

\footnotetext{
${ }^{36}$ Tais exemplos correspondem aos apresentados em Pilati (2006, p. 199).
} 
Diante disso, a autora propõe as estruturas a seguir, para a ordem $\mathrm{V}(\mathrm{O}) \mathrm{S}$ no $\mathrm{PB}$, com os diferentes tipos de verbos:

a) Possibilidades de ordenação com verbos inacusativos

Oração: Aqui / pro ${ }^{\text {loc }}$ chegaram as cartas.

(26)

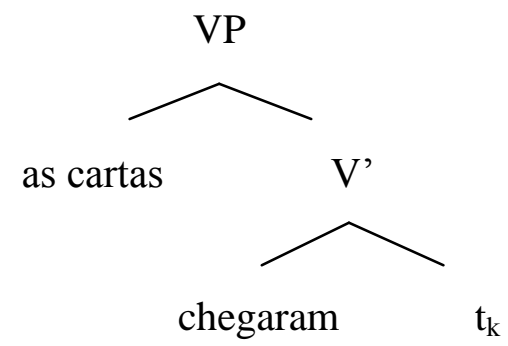

(Pilati, 2006: 212)

Inserção de vP e de T

(27)

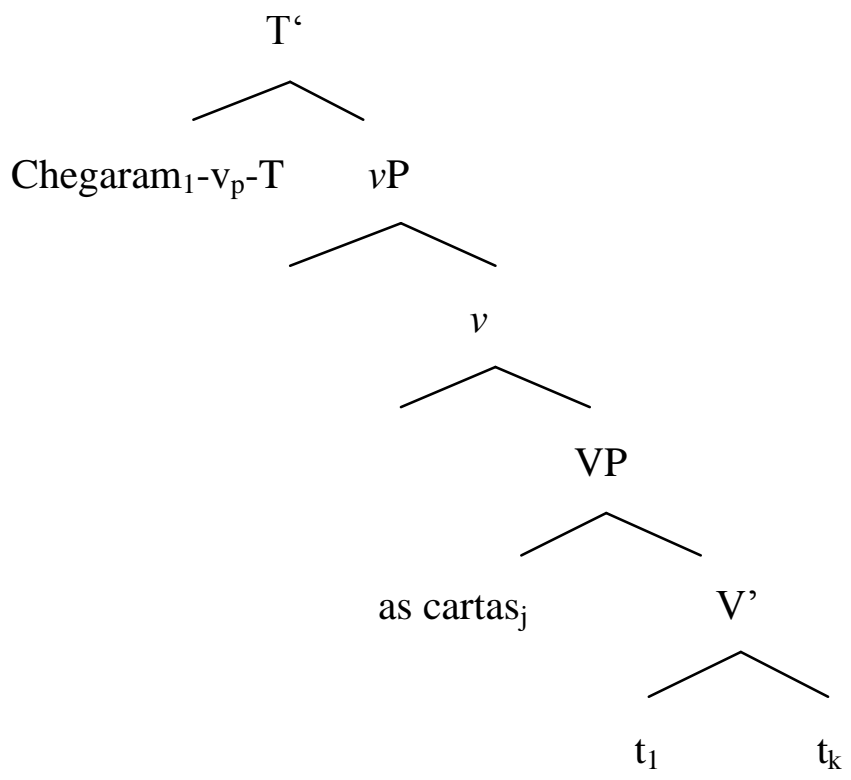

(Pilati, 2006: 212) 
(28)

\section{TP}

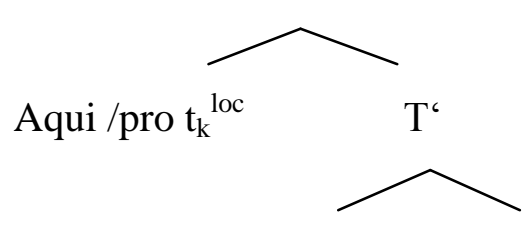

Chegaram $_{1}-\mathrm{v}_{\mathrm{p}}-\mathrm{T} \quad v \mathrm{P}$

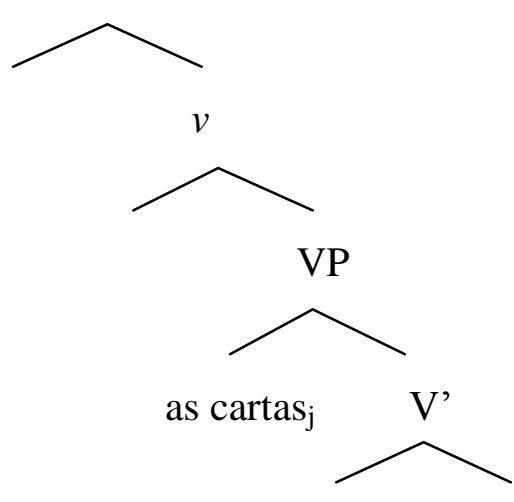

$\mathrm{t}_{1} \quad \mathrm{t}_{\mathrm{k}}$

(Pilati, 2006: 213)

b) Derivação com verbos inergativos

Oração: Hoje ligou a Maria,/ pro ${ }^{\text {loc }}$ ligou a Maria.

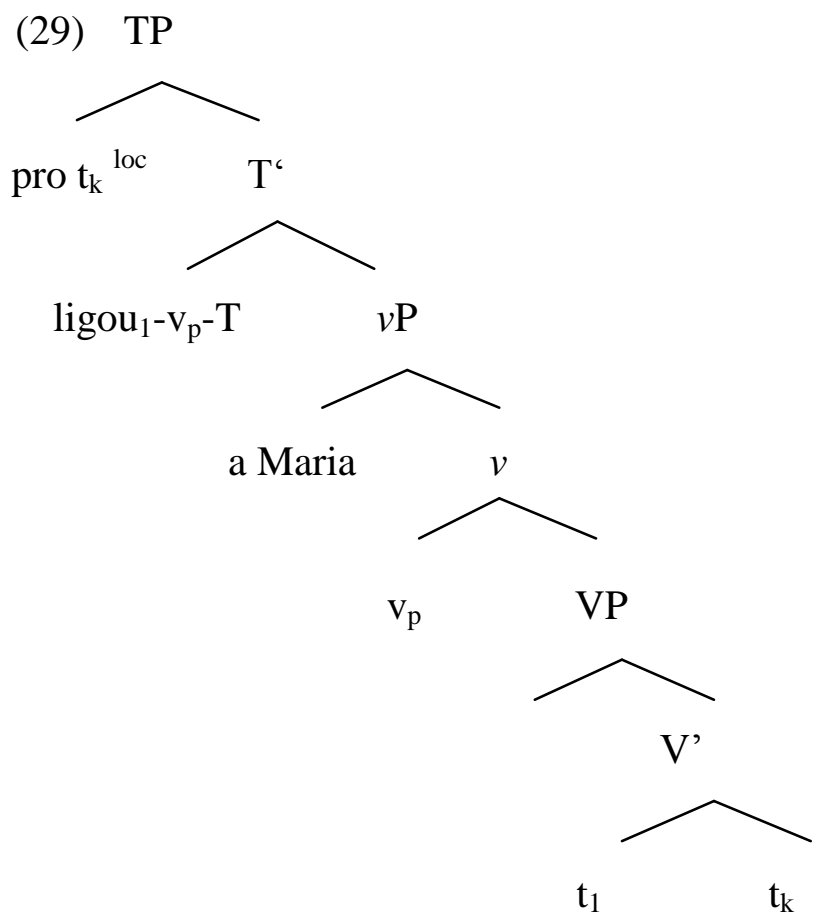

(Pilati, 2006: 213) 
c) Possibilidades de ordenação com verbos transitivos em narrações concomitantes ou em orações com verbos leves

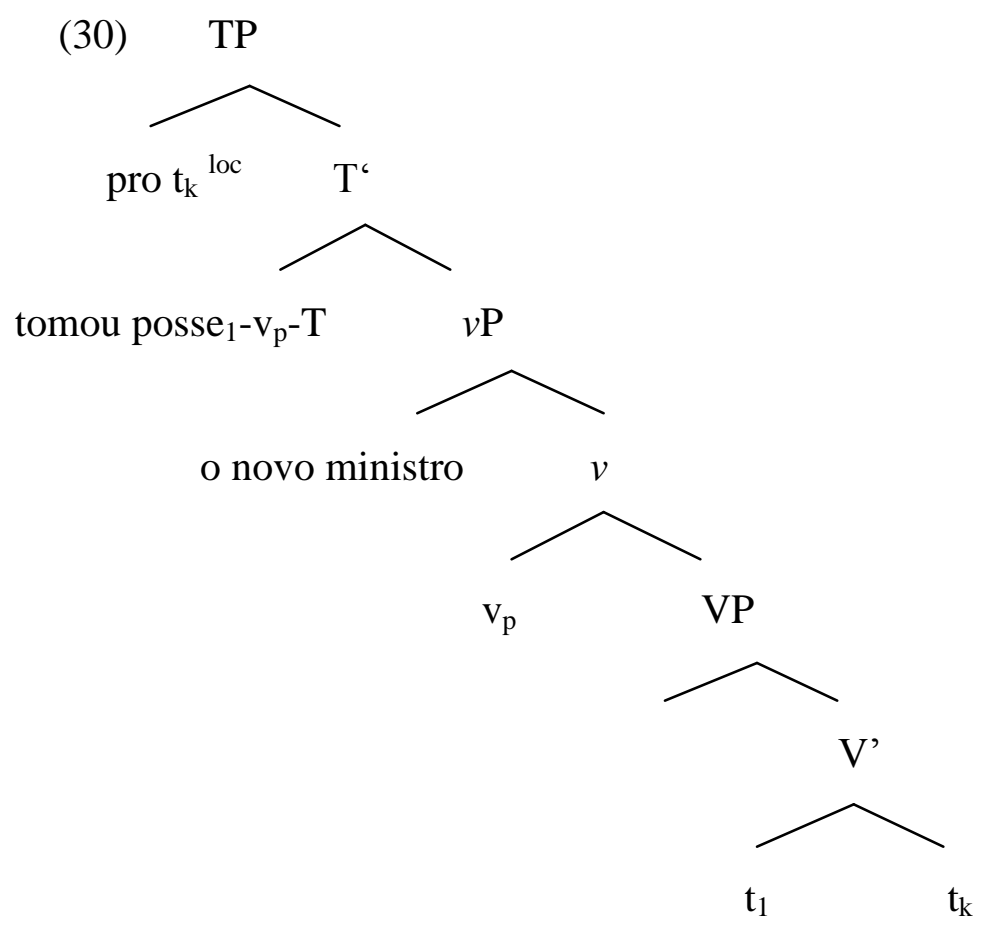

(Pilati, 2006: 214)

Demais verbos transitivos não podem apresentar inversões locativas por uma razão sintática: o objeto manifesta Caso Acusativo dentro do vP, e bloqueia a possível relação de probe-goal entre T e Loc (como se fosse uma forma de Restrição de Intervenção, ver Cap. 1 seção 1.4).

Pilati (2006) conclui seu estudo, observando que a hipótese de que as estruturas VS do PB licenciam um pronome nulo com referência locativa na posição pré-verbal permite ainda dar conta de outros aspectos da gramática do $\mathrm{PB}$, tais como o enfraquecimento do sistema de concordância verbal (cf. Duarte 1993, 1995, entre outros, citados pela autora) e o aparecimento das estruturas referidas como de tópico-sujeito (cf. Pontes 1987).

Retomaremos essas questões adiante, apresentando estudos subsequentes a Pilati (2006), em que a investigação dessa hipótese é avançada.

\subsubsection{O PP locativo na posição de sujeito no PB: Avelar e Cyrino (2008a, b; 2009); Avelar (2009)}

A hipótese da presença do PP locativo na posição de sujeito no PB é investigada em estudos posteriores a Pilati (2006), como Avelar e Cyrino (2008a, b; 2009); Avelar (2009). De acordo com esses autores, a estrutura no PB pode ser uma contribuição de línguas da família 
Bantu (vejam-se as características citadas na análise de Bresnan (1994) para o chicheŵa), diante da situação de contato linguístico no período da colonização, já que eram línguas faladas pela maioria dos escravos que chegaram ao Brasil entre os séculos XVI e XIX.

Avelar e Cyrino, 2009 (p.1) analisam estruturas como as ilustradas a seguir:

(31) a. No meu quarto faz muito barulho durante a noite.

b. Na fazenda do meu tio planta todos os tipos de verdura.

A hipótese inicial dos autores é de que, na ausência do argumento externo, o PP locativo pode checar o EPP em T(empo):

(32) a. Naquela loja vende muitos livros.

b.
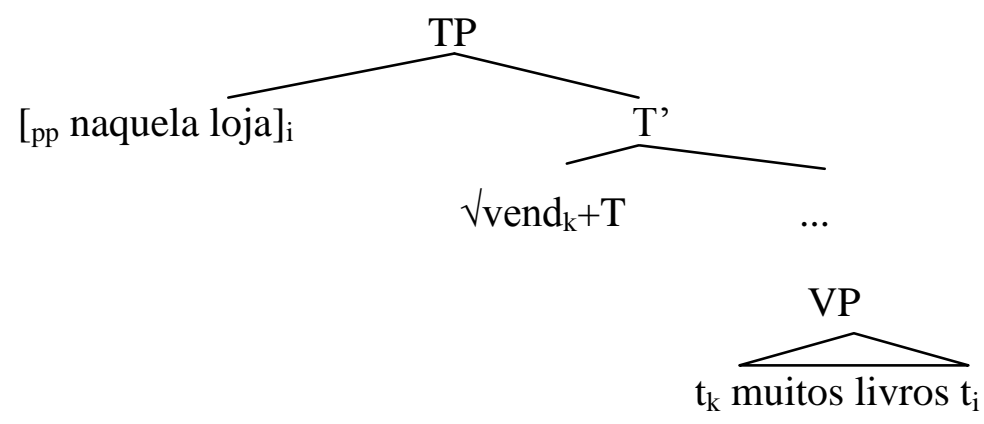

Avelar e Cyrino (2008b) e (2009) retomam e ampliam a análise proposta em Avelar e Cyrino (2008a). Os autores iniciam ressaltando que, à primeira vista, não sendo o pronome se indeterminador (ou apassivador) usual no PB, como ilustra (33), construções como (32) poderiam resultar do desuso desses pronomes em tais contextos. No entanto, ressaltam que essa hipótese não explica o fato de, em PB, o locativo ser obrigatório nesses casos (p.2):

(33) a. *Vende muitos livros.

b. Lál Naquela loja vende muitos livros.

c. (Naquela loja) vende(m)-se muitos livros.

Comparando estruturas como (33a) com (33b), Avelar e Cyrino (2009) afirmam que se a queda do se fosse uma explicação, a construção em (33a) deveria ser licenciada sem o locativo da mesma maneira que, em (33c), a presença ou ausência do locativo não é importante na garantia de aceitabilidade. 
Os autores explicam que a inversão locativa abrange os casos em que constituintes locativos, que são tidos comumente como não-argumentais, ocorrem na posição identificada como a posição gramatical do sujeito. No entanto, eles ressaltam que as línguas naturais se comportam de maneira heterogênea no que diz respeito às propriedades que envolvem o fenômeno, distinguindo-se "quanto a propriedades de concordância e à especificidade da estrutura argumental que licencia a inversão" (p.3).

Analisando as propriedades de concordância, os autores apontam duas possibilidades de concordância verbal, podendo o verbo concordar com o constituinte locativo em posição pré-verbal ou com o constituinte que corresponde ao sujeito argumental em posição pósverbal. Essas possibilidades são ilustradas pelos autores com dados do inglês, em que a concordância se faz com o constituinte pós-verbal; e com dados do chicheŵa (família Bantu), em que a concordância se dá com o locativo pré-verbal (p.3):

(34) Inglês

From such optical tricks arise all the varieties of romantic hallucination...

(35) Chicheŵa

a. ku-um-dzi ku-na-bwér-á a-lendô-wo

'To the village came those visitors.'

b. m-mi-têngo mw-a-khal-a a-nyăni

'In the trees are sitting baboons.'

No que diz respeito à estrutura argumental que licencia a inversão locativa, Avelar e Cyrino (2009) apontam a existência de, pelo menos, dois padrões: em um, a inversão locativa é permitida preferencialmente em construções inacusativas, como exemplifica o inglês; e, em outro, a inversão locativa é permitida em uma variedade mais ampla de construções, como exemplifica o kinyarwanda (língua Bantu), que admitem a inversão locativa com verbos inergativos e transitivos, com a restrição de que os argumentos interpretados como agente e tema não ocorram juntos na mesma sentença (p.4):

(36) a. In the distance APPEARED the towers and spires of a town [...].

b. * In the cafés of Paris TALK many artists. 
(37) Kinyarwanda

a. kw’ íisôko ha-Ø-guz-w-e ibi-íntu bi-taandátu

'At the market were bought six things.'

b. um cyûmba ha-Ø-ríi-r-iye umwáana

'The child ate in the room.'

Comparando as estruturas argumentais que licenciam a inversão locativa em inglês e em línguas Bantu, Avelar e Cyrino (2009) demonstram que o PB permite inversão locativa em construções com verbos inergativos e transitivos, como observado em línguas como o kinyarwanda. Assim, na análise dos autores, os dados abaixo são resultado de uma derivação em que o PP locativo é realizado na posição gramatical de sujeito, em termos minimalistas, em [Spec, TP] (p.5):

(38) verbos inacusativos

a. Na casa da Maria chegou algumas cartas.

b. No meio da festa apareceu uns convidados estranhos.

(39) verbos inergativos

a. Naquele quarto dormiu várias pessoas.

b. Naquela fábrica trabalha muitos amigos meus.

(40) verbos transitivos ergativizados

a. Naquele bairro aluga casa de todos os preços.

b. Na loja do Pedro não conserta sapato de couro.

(41) verbos transitivos e inergativos sem tema e/ou agente

a. Nas cidades do interior não seqüestra tanto como nas grandes capitais.

b. No casa do João cozinha todos os dias.

Avelar e Cyrino (2009) apresentam dois testes que buscam verificar o estatuto do PP locativo como ocupante da posição gramatical de sujeito nos dados (38) a (41). O primeiro teste refere-se à obrigatoriedade do constituinte locativo em construções com sujeito pósverbal; o segundo teste refere-se ao movimento do locativo em estruturas com verbo de alçamento. 
Com o primeiro teste, os autores demonstram a obrigatoriedade do PP locativo quando o sujeito é pós-verbal, em contraste com a opcionalidade deste constituinte quando o sujeito argumental é pré-verbal (p.6) ${ }^{37}$ :

(42) a. (Naquele quarto) várias pessoas dormiram.

b. *(Naquele quarto) dormiu várias pessoas.

Avelar e Cyrino (2009) concluem que a obrigatoriedade do PP locativo pode ser explicada adequadamente se partirmos do pressuposto de que o locativo satisfaz a condição EPP nos contextos em que o sujeito é pós-verbal, como em (42b). Essa situação pode ser ainda comparada ao que ocorre em (43a, b), em que a presença do locativo licencia a estrutura em que o sujeito não está gramaticalmente presente.

(43) a. (Naquela loja) todos os tipos de livro vendem.

b. *(Naquela loja) vende todos os tipos de livro.

Diante disso, os autores ressaltam a necessidade de assumir que o locativo está em [Spec, TP/IP], ou não se poderá tratar a obrigatoriedade do PP locativo em termos de satisfação do EPP.

Em nota, os autores observam que PPs locativos podem salvar as sentenças também se estiverem em posição final (p.6):

(44) a. Vende muitas coisas naquela loja.

b. Grava todo tipo de filme nesse meu DVD.

Para contraste com os dados acima, os autores analisam os seguintes dados (p.6):

(45) a. $\left(\mathrm{ele}_{\mathrm{i}}\right)$ não quis almoçar hoje, o Roberto ${ }_{\mathrm{i}}$

b. $\left(\mathrm{ela}_{\mathrm{i}}\right)$ vai comprar um carro novo, a Maria $\mathrm{i}_{\mathrm{i}}$

c. $\left(\right.$ elas $\left._{\mathrm{i}}\right)$ comeram a comida toda, as crianças ${ }_{\mathrm{i}}$

\footnotetext{
${ }^{37}$ Note-se que o contraste em (42) e (43) é originalmente citado em Pilati $(2002,2006)$, para indicar as restrições à ocorrência da ordem VS no PB (cf. seção 4.1.1), bem como para dar sustentação à hipótese de que tais construções no PB são realizadas em uma configuração de 'inversão locativa'.
} 
Argumentam que, em (45), os dados demonstram que sujeitos (nulos) podem ser licenciados em posição final, desde que sejam interpretados como tópico e/ou sejam retomados por um pronome pessoal anteposto ao verbo. Comparando com os dados em (44), os autores observam que os locativos em posição final também podem ser retomados por elementos adverbiais pronominais antepostos ao verbo (46), o que reforça a hipótese dos autores de que PPs locativos podem garantir a aceitabilidade da sentença quando entram na posição tipicamente ocupada pelo sujeito argumental.

(46) a. $\left(l a_{i}\right)$ vende muitas calças, naquela loja

b. $\left(a i_{i}\right)$ grava todo tipo de filme, nesse теи $D V D_{i}$

c. $\left(\right.$ lá $\left._{i}\right)$ trabalha vários amigos meus, naquela loja

Com o segundo teste, os autores demonstram que os PPs locativos, com o verbo de alçamento parecer, ficam antepostos ao verbo, caso o sujeito argumental da sentença permaneça posposto. Esse fato revela a semelhança entre locativos e sujeitos nominais no que diz respeito à obrigatoriedade de serem movidos para [Spec, TP] nas construções de alçamento. Apoiando-se nesses fatos, os autores afirmam que o PP locativo pode satisfazer a condição EPP também nessas estruturas (p.6):

(47) a. *Parece na casa da Maria chegar muitas cartas.

b. Na casa da Maria parece chegar muitas cartas.

(48) a. *Parece naquele shopping trabalhar muita gente.

b. Naquele shopping parece trabalhar muita gente.

Os autores também analisam o fato de o PP locativo não desencadear concordância na posição de sujeito. Em particular, em Avelar e Cyrino (2009), destacam que o PB popular possui uma opcionalidade de concordância sujeito-verbo (p.9):

(49) Os menino comeu/ comeram o bolo.

Essa concordância variável, para os autores, está relacionada à possibilidade de a categoria $\mathrm{T}$ poder ser licenciada sem traços- $\phi$. Ou seja, em PB, constituintes que têm como 
núcleo categorias sem traços- $\phi$, tal como as preposições, podem ser licenciadas na posição de sujeito, já que a concordância sujeito-verbo não é obrigatória.

Antes de apresentar a continuidade da análise, desenvolvida em Avelar (2009), gostaríamos de fazer algumas considerações em relação à análise proposta nos estudos citados. Em primeiro lugar, consideramos válidos - e específicos do PB - os dados que ilustram a ocorrência do PP locativo na primeira posição (em relação ao verbo), conforme apresentados pelos autores. Consideramos ainda plausível a hipótese de que, nesses casos, os PP locativos ocupem a posição de sujeito, configurando-se a situação de inversão locativa, não só para os casos de VS, conforme postulado por Pilati (2006) (cf. seção 4.1.1), como também para os casos em que o argumento externo do verbo transitivo ou inergativo não está realizado sintaticamente, pela ausência de categoria morfossintática indeterminadora do sujeito (cf. dados em (33)). No entanto, discordamos do julgamento de gramaticalidade dos dados (47) e (48), pois entendemos que a ocorrência do PP locativo é possível se for criado um contexto adequado, como, por exemplo, uma situação de foco contrastivo - 'Parece NA CASA DE MARIA ( não na de João) chegar muitas cartas.${ }^{38}$ Finalmente, a hipótese de que a concordância variável no PB indica que o núcleo T pode ser licenciado independentemente de traços phi, não nos parece adequada como fator responsável por determinar a ocorrência do PP locativo na posição de sujeito. Essa questão será retomada.

Avelar (2009) dá continuidade à análise de Avelar e Cyrino (2009), propondo que o paradigma flexional do PB autoriza relações de concordância entre o verbo e um locativo preposicionado. Além dos argumentos da obrigatoriedade e das construções com o verbo de alçamento parecer, o autor traz o argumento da coindexação entre sujeitos de orações coordenadas. No PB, o sujeito nulo referencial de uma oração coordenada necessita ser coindexado ao sujeito da oração seguinte (p.236):

(50) [Muita gente $]_{\mathrm{i}}$ trabalha naquela fábrica $\mathrm{ev}_{\mathrm{i}}$ mora do outro lado da cidade.

Em (51) pode-se notar que se um constituinte locativo preposicionado estiver na mesma posição do DP em (50), a categoria vazia é coindexada a ele (p.236):

\footnotetext{
${ }^{38}$ Outro aspecto a ser observado é que a estrutura de alçamento citada deve ser avaliada em termos da presença do infinitivo flexionado na oração encaixada, embora na $3^{a}$ pessoa do singular essa categoria não tenha um correlato morfofonológico. Na presença do infinitivo flexionado, o alçamento do sujeito gera uma situação de hiper-alçamento. Agradeço à Profa. Heloisa Salles (c.p.) pela observação, e por apontar o estudo de Sandoval (2004) na discussão das especificidades desse fenômeno no PB (em oposição ao PE). Deixaremos a análise dessa questão para pesquisa futura.
} 
(51) [Naquela fábrica $]_{\mathrm{i}}$ trabalha muita gente e ainda assim $\mathrm{cv}_{\mathrm{i}}$ vai contratar mais cem funcionários até o final do ano.

Para o autor, a possibilidade de coindexação em (51) é mais um argumento que demonstra que o PP locativo anteposto ao verbo se comporta como um elemento que ocupa a posição gramatical de sujeito quando o sujeito argumental está em outra posição ${ }^{39}$.

Avelar (2009) trata os locativos preposicionados como projeções cujo núcleo é um pronome adverbial (como aqui, aí e lá) que pode ser realizado fonologicamente ou não. $\mathrm{O}$ autor propõe, então, que esses pronomes, referidos como categoria Loc, nucleiam um LocP (Locative Phrase), sendo a projeção do PP locativo tratada como complemento de Loc, assumindo as configurações em (53) para a arquitetura sintática dos dados em (52):

(52)
a. (aqui) na loja
b. (aí) sobre a mesa

(53)

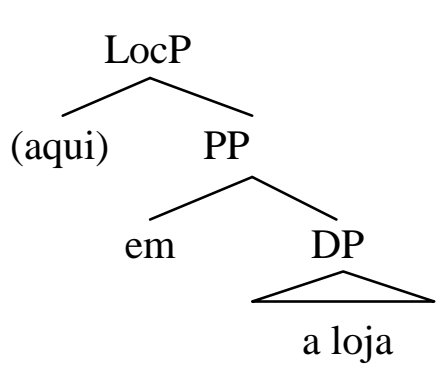

b.

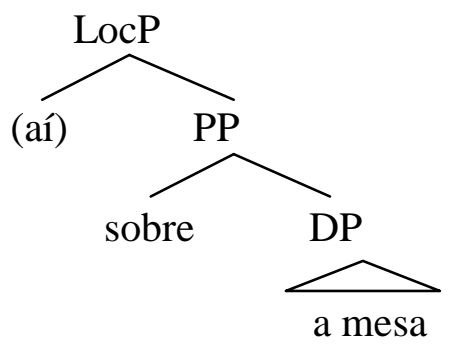

Com esse argumento, o autor explica o requisito gramatical que autoriza a ocorrência do PP locativo em [Spec, TP], pois atribui a ele um estatuto nominal, já que o núcleo do sintagma locativo em questão não é a preposição introdutora do PP locativo, mas um pronome adverbial, que, realizado fonologicamente ou não, introduz a preposição. Sendo o pronome adverbial uma categoria nominal, o autor salienta que, na posição de sujeito, ele pode ser realizado sozinho (54a), co-ocorrer com o PP locativo (54b) ou, ainda, estar presente como uma categoria nula $(54 \mathrm{c})$ :

\footnotetext{
${ }^{39}$ Igualmente, o teste da retomada anafórica do sujeito nulo da oração coordenada, pelo sujeito (expresso) da primeira oração foi usado em Pilati (2006), a fim de postular a realização do PP locativo (na estrutura VS) na posição de sujeito.
} 
(54) a. Lá vende muitos livros.

b. Lá no shopping vende muitos livros.

c. No shopping vende muitos livros.

Assumindo que se trata de uma projeção de categoria nominal, o sintagma locativo (LocP/PP $\mathrm{P}_{\text {loc }}$ ) pode ocupar a posição de sujeito e os traços- $\phi$ de $\mathrm{T}$ podem concordar com o $\mathrm{LocP} / \mathrm{PP}_{\text {loc }}$, já que qualquer forma pronominal deve ser capaz de desencadear concordância.

Avelar (2009) aponta que casos em que o $\mathrm{LocP}_{\mathrm{PP}} \mathrm{loc}_{\mathrm{lc}}$ ocorre no final da sentença (55) poderiam ser um contra-argumento para a ideia de que o sintagma em questão ocupa a posição de sujeito, pois, apesar de ser necessário para garantir a boa-formação da sentença, pode ser realizado fora da posição de sujeito e, como a realização nessa posição não é necessária, não seria adequado associar sua ocorrência ao requerimento de Caso. Os dados abaixo ilustram a situação (p.242):

(55) a. Vende muitos livros (lá) naquele shopping.

b. Dorme criança (aqui) nesse quarto.

c. Planta todos os tipos de legume (aí) nessa fazenda.

d. Estuda muita gente conhecida (lá) na Unicamp.

O autor explica que, uma vez que Agree é estabelecida à distância (a interação entre os traços- $\phi$ de $\mathrm{T}$ e os de DP acontece antes de o sujeito ser movido para [Spec, TP]), T estabelece a concordância com o $\mathrm{LocP} / \mathrm{PP}_{\text {loc }}$ quando ele ainda se encontra fora da posição esperada. Assim, o autor considera que, por apresentar uma natureza inerentemente adverbial, típica de constituintes em configuração de adjunção, o locativo é, a princípio, um adjunto de VP (56), contudo, nesta posição, o LocP/PP $\mathrm{PP}_{\text {loc }}$ pode ser detectado pelos traços- $\phi$ de $\mathrm{T}$ e ter valoração com a marca de $3^{\mathrm{a}}$ pessoa do singular (p.242). 
(56)

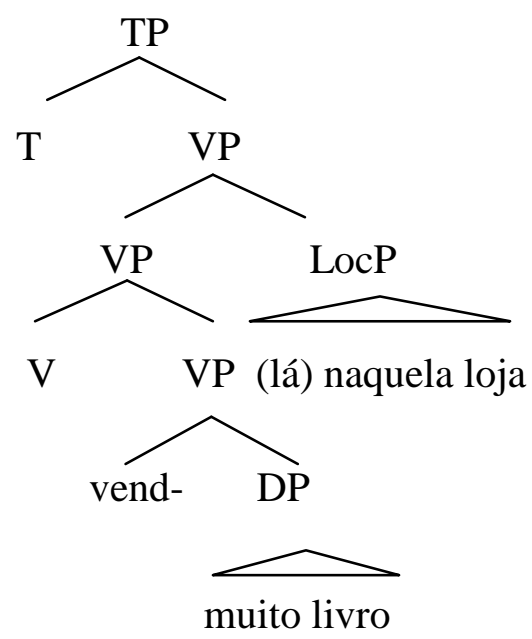

(57)

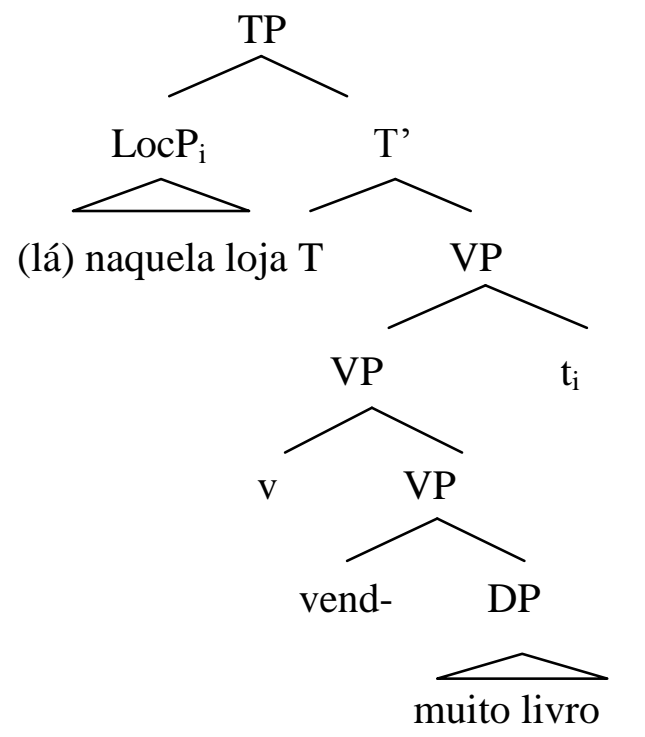

Na proposta de Avelar (2009) não se trata do contraste entre a presença ou ausência da preposição nos sintagmas em questão em posição de sujeito, "mas entre um sintagma nominal que se realiza na forma de um DP (aquela loja), e outro que se realiza como a projeção de um pronome adverbial dêitico sem realização fonológica", o LocP (p. 245). Nesta perspectiva, o PP é introduzido pela preposição apenas superficialmente, pois, na computação sintática o sintagma é introduzido por um pronome adverbial, que pode ser nulo.

Ainda sobre a concordância, Avelar (2009) ressalta que o paradigma flexional do PB, atualmente, apresenta os traços- $\phi$ de $T$ numa versão defectiva $\left(\mathrm{T}_{\mathrm{DEF}}\right)$, pois o traço de número está ausente, havendo apenas o traço de pessoa. Dessa maneira, temos uma marca para a primeira pessoa (eu canto) e outra para as demais [tu/ você/ ele/ nós (a gente)/ vocês/ eles canta]. Essa peculiaridade no paradigma flexional do PB pode, na análise do autor, interferir na determinação do tipo de categoria que pode interagir com os traços- $\phi$ de $T$ na operação 
Agree. Com esse sistema flexional, uma categoria que só apresente a marca de pessoa, e não de número, como os pronomes adverbiais, que nucleiam o Loc $\mathrm{P} / \mathrm{PP}_{\mathrm{loc}}$, pode interagir com $\mathrm{T}_{\mathrm{DEF}}$.

\subsection{NPs locativos na posição de sujeito}

A análise de Avelar (2009) explica a ocorrência de PPs locativos na posição de sujeito no $\mathrm{PB}$, mas, conforme o autor reconhece, não aborda os casos referidos nos estudos de Pontes (1986, 1987), em que o PP locativo perde a preposição e realiza-se como NP locativo, anteposto ao verbo, podendo controlar a concordância:

(58) a. Essa casa bate sol.

b. Essas casas batem sol.

Cabe então perguntarmos se há fatores sintáticos que desencadeiam a concordância com advérbios realizados como NPs e bloqueiam-na com advérbios realizados como PPs. Se há tais fatores, quais propriedades possuem quando realizados como NPs?

Adotando um modelo teórico gerativista, propomos que há fatores sintáticos que determinam a distribuição das categorias associadas à posição de sujeito. Supomos, inicialmente, que o PP na posição de sujeito bloqueia o desencadeamento de concordância assim como um advérbio; enquanto, em uma construção com NP, temos traços sintáticos que desencadeiam a concordância e licenciam o NP locativo na posição de sujeito. É o que discutiremos na próxima seção, considerando inicialmente as construções referidas por Larson (1985) como Bare-NP Adverbs, as quais alternam a realização como PP.

\subsubsection{Bare-NP Adverbs: Larson (1985)}

Larson (1985) examina sintagmas nominais que possuem a habilidade de funcionar como modificadores adverbiais, sem o acompanhamento de preposições ou de qualquer outro indicador do status de adjunção. São os chamados bare-NP adverbs, como ilustra o exemplo abaixo (Larson, 1985: 595):

(59) a. I saw John [NP that day].

'Eu vi João [NP aquele dia]'. 
Segundo o autor, o inglês moderno exibe bare-NP adverbs em uma variedade de funções semânticas, entre elas a de modificador temporal e locativo. ${ }^{40}$ Muitos NPs que se referem a um ponto ou período de tempo podem funcionar como modificadores temporais, por exemplo: NPs nucleados por nomes comuns que se referem a unidades em calendários, como dias, meses e anos (60a); NPs que se referem a um intervalo do calendário anual ou que funcionam como nomes próprios para períodos de tempo (60b); NPs nucleados pelo nome comum time (tempo) (60c); a forma temporal then (então) e os dêiticos (60d) now (agora), yesterday (ontem), today (hoje) e tomorrow (amanhã) (Larson, 1985: 596) ${ }^{41}$ :

(60) a. John arrived [that moment/ minute/ hour/ day/ week/ month/ year].

'João chegou [aquele momento/ minuto/ hora/ dia/ semana/ mês/ ano]'.

b. John arrived [the previous April/ March 12th/ Sunday/ the Tuesday that I saw Max].

'João chegou [o Abril passado / 12 de Março/ Domingo/ a Terça anterior a que eu vi Max]'.

c. John has been here [few times that I can recall].

'João esteve aqui [poucas vezes que eu possa lembrar]'.

d. John arrived [yesterday] / John will arrive [tomorrow] / John is arriving [now].

'João chegou [ontem] / John chegará [amanhã] / John está chegando [agora]'

Para Larson, esses dados demonstrariam que a capacidade de ocorrer como bare-NP adverb é estritamente semântica, assim, qualquer NP que designa um período de tempo poderia funcionar dessa maneira. Entretanto, como demonstram os dados abaixo, alguns nomes que se referem a um período de tempo (61a) ou que são claramente temporais em sua referência (61b), não podem aparecer como modificadores temporais sem uma preposição apropriada. Dessa maneira, o critério semântico é um motivador para essas ocorrências, mas não parece ser o único critério (Larson, 1985: 596):

\footnotetext{
${ }^{40} \mathrm{O}$ autor também analisa adverbiais de direção e de modo, mas não serão considerados neste ponto.

${ }^{41}$ A tradução em PB não contemplará todos os NPs nus-Adverbiais porque o PB é mais restritivo do que o inglês em relação à ocorrência dessas estruturas.
} 
(61) a. John arrived *(on) that occasion /*(during) this vacation.

'João chegou * $(\mathrm{em})$ aquela ocasião / *(durante) essas férias.

b. John stayed in New York *(during) that period of his life /*(before) that interval.

'João ficou em Nova Iorque *(durante) aquele período de sua vida / * (antes de) esse intervalo.

Quanto aos bare-NP adverbs locativos, o autor afirma que sua distribuição é paralela àquela dos locativos em geral, mas o número de formas permitidas é muito mais restrito, pois além das proformas locativas e dêiticos, os únicos bare-NP adverbs locativos são aqueles nucleados por um nome comum place (lugar), e eles podem aparecer com vários determinantes (Larson, 1985: 597):

(62) You have lived [someplace warm and sunny] / [every place that Max has lived].

Você viveu [algum lugar quente e ensolarado] / [cada lugar que Max viveu]. PB*

Há bare-NP adverbs locativos com a forma locativa there (lá) e o dêitico here (aqui) (Larson, 1985: 597):

(63) You have lived [here/ there].

'Você viveu [aqui/ lá]'.

Nomes próprios para locativos, que seriam análogos a NPs como Thursday (QuintaFeira), não podem aparecer como bare-NP adverbs (Larson, 1985: 597):

(64) You have lived *(in) Germany.

'Você viveu *(em) Alemanha'.

Além disso, nomes que possuem sentido próximo ao de place (lugar) não podem ser núcleos de um bare-NP adverb adjunto, mostrando que, como no caso das expressões temporais, a restrição para possíveis bare-NP adverbs não é apenas semântica (Larson, 1985: 597): 
(65) You have lived *(at) some location/ address/ area near here.

'Você viveu *(em) algum lugar/ endereço/ área próxima aqui'.

$\mathrm{Na}$ superfície, os bare-NP adverbs têm a forma de NP simples e podem ser acompanhados por vários determinantes idênticos aqueles encontrados em casos canônicos de argumentos NPs: some (alguns), every (cada), a (um), the (o), etc.. Eles também podem ser modificados por orações relativas restritivas, como em (Larson: 1985: 598):

(66) You pronounced my name [every way [that anyone could imagine]].

Você pronunciou meu nome [todas as maneiras [que qualquer um poderia imaginar]] $\mathrm{PB}^{*}$.

Além disso, os bare-NP adverbs podem ocupar posições normalmente preenchidas somente por NPs (Larson, 1985: 598):

(67) a. Every morning's lecture.

b. The lecture every morning.

'A palestra de cada manhã'

(68) a. Yesterday's refusal.

b. The refusal yesterday.

'A recusa de ontem'.

Uma vez que a posição de especificador genitivo é disponível somente para NPs, every morning e yesteday são, para o autor, NPs em uso adverbial.

$\mathrm{O}$ autor aponta ainda que bare-NP adverbs também mostram distribuição paralela com outras categorias adverbiais, alternando livremente com AdvP, PP e S' (Larson, 1985: 599):

(69) Petter put the letter $[* \varnothing] /[\mathrm{NP}$ someplace] / *[NP some location] / [PP in the mailbox] / [s' where Max would find it].

'Petter colocou a carta [* $\left.{ }^{*}\right]$ / [NP algum lugar] / *[NP algum local] / [PP no correio] / [s, onde Max iria encontrá-la]'. 
Considerando os dados analisados, Larson (1985) afirma que os fatos centrais que dizem respeito aos bare-NP adverbs são: (1) os membros dessa classe em inglês são determinados no âmbito lexical, pois a habilidade de um NP ocorrer como bare-NP adverbial depende crucialmente de um nome específico que aparece em seu núcleo; (2) Bare-NP adverbs têm a forma interna de NPs, mas função e distribuição de categorias adverbiais como PP, AdvP e S'.

Larson (1985) afirma que a razão central de os elementos adverbiais serem problemáticos é o fato de que eles parecem entrar em conflito com a hipótese que a distribuição de expressão nominal em uma língua deve ser explicada por meio de regras estabelecidas em termos de categorias sintáticas. Sob essa visão, de que a distribuição é questão de categoria sintática, o autor salienta que espera-se que sintagmas que compartilham propriedades distribucionais compartilharão propriedades categoriais, o que torna a sintaxe de adverbiais problemática, pois, há uma coleção de sintagmas que, intuitivamente, têm uma função comum como modificador, conforme observamos nos dados em (69), e compartilham comportamento distribucional. Consequentemente, espera-se que compartilhem propriedades categoriais. Se assim for, a categoria de adverbiais é muito ampla, incluindo, pelo menos, PP, AdvP, S' e NP. No entanto, PP, AdvP, S' e NP não constituem uma classe natural em qualquer conjunto geralmente aceito de traços sintáticos.

Larson faz uma breve exposição da análise de Bresnan e Grimshaw (1978), que tratam os bare-NP adverbs como sintagmas preposicionais sem núcleo, conforme a estrutura ilustrada abaixo (Larson, 1985: 601):

(70)

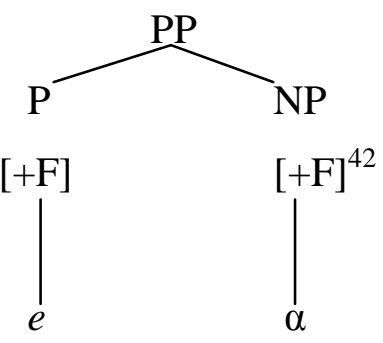

De acordo com (70), bare-NP adverbs são NPs que ocorrem em um PP cujo núcleo é uma categoria vazia [ $\left.{ }_{\mathrm{pP}} e\right]$. O nódulo NP dominando $\alpha$ explica a estrutura Det $\mathrm{N}$ dos bare-NP adverbs, sua ocorrência acompanhando orações relativas e em posições reservadas

${ }^{42}$ Onde F é tempo, locativo, direção ou modo. 
exclusivamente aos NPs. O nódulo PP explica propriedades adverbiais desses sintagmas, sua habilidade de ocorrer com outros advérbios e com o intensificador right.

Para Larson, a estrutura em (70), proposta por Bresnan e Grimshaw (1978), busca explicar por que somente certas classes de NPs determinadas lexicalmente podem ocorrer como bare-NP adverbs. Para ilustrar a ideia básica dessa proposta, Larson utiliza o caso dos locativos: as preposições locativas no inglês são marcadas com [+Loc] e os nomes como place (lugar), here (aqui) e there (lá) são também marcados por [+Loc]. Assim, qualquer PP nucleado por uma preposição [+Loc] será [+Loc] e, similarmente, qualquer NP nucleado por um nome [+Loc] será [+Loc].

Supondo que a inserção de itens gramaticais na estrutura de base é opcional, a gramática irá gerar estruturas nas quais a opção de inserir a preposição não é exercida, como ilustrado abaixo (Larson, 1985: 601):

(71) a. PP
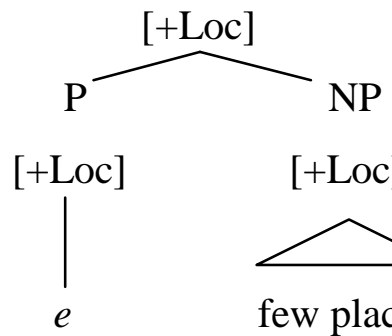

\section{[+Loc]}

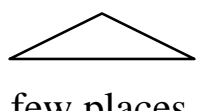

few places

'poucos lugares' b. PP

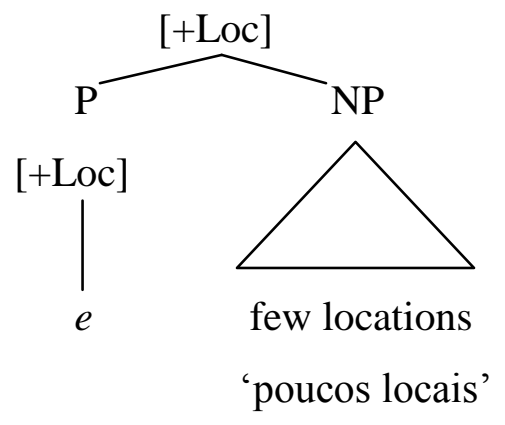

Ao mesmo tempo, Larson aponta que, se considerarmos que a gramática também tem meios de descartar estruturas de superfície que contêm nódulos não preenchidos por material lexical, tais configurações resultariam em agramaticalidade se nenhuma regra a mais se aplicar. Então, para resgatar bare-NP adverbials da má formação, Bresnan e Grimshaw, segundo Larson (1985), propõem uma regra de apagamento que elide um nódulo P antes de um NP que concorda com ele no traço [+F] (Larson, 1985: 602):

(72) P Deletion

$$
\begin{array}{ll}
\mathrm{P}>\varnothing / & \mathrm{NP} \\
{[+\mathrm{F}]} & {[+\mathrm{F}]}
\end{array}
$$

Considerando (72), [Р $e$ ] pode ser apagada em (71a), permitindo a boa formação com bare-NP adverb (few places). Por outro lado, a categoria vazia em (71b) não pode ser 
eliminada, por isso, o NP few locations é descartado como bare-NP adverb pela restrição encontrada no nódulo não preenchido. Da mesma maneira, as classes de possíveis bare-NP adverbs de tempo, direção e modo são controlados pela distribuição de traços de [+Temp], [+Dir], [+Man] e pela regra de apagamento (P Deletion).

Para Larson (1985), a proposta de Bresnan e Grimshaw (1978) deixa clara a posição de que a distribuição é largamente uma função de categoria sintática. O comportamento adverbial de bare-NP adjunto é analisado como membro de uma categoria PP, e as propriedades que permitem certos NPs funcionarem como bare-NP adverbs são analisadas em termos de traços e regras que lhes permitem aparecer não acompanhados de preposição. Para Larson, a dificuldade com essa proposta é que, dada a observação de que bare-NP adverbs compartilham, geralmente, a distribuição de todas as outras categorias adverbiais, a atribuição do status de PP teria de se aplicar também a orações adverbiais como when John arrived (quando John chegou) e a advérbios como subsequently (subsequentemente) e locally (localmente). Além disso, o autor aponta que a regra P Deletion e a restrição (não declarada) em nódulos não preenchidos não tem suporte empírico na gramática.

Buscando aprimorar a análise sobre bare-NP adverbs, o autor relembra uma característica peculiar dos NPs: eles precisam de Caso. Passa então a considerar a sentença abaixo (Larson, 1985: 606):

(73) John hit the ball over the fence [NP that day].

'John bateu a bola por cima da cerca [NP aquele dia]'.

Segundo o autor, that day (aquele dia) não tem atribuidor de Caso potencial, assim, a expectativa é a de que a sentença fosse agramatical, entretanto, é bem formada. Então, sugere que bare-NP adverbs possuem uma maneira especial de receber Caso: a atribuição ocorre através de um traço especial $[+\mathrm{F}]$, que é carregado por esses nomes. Este traço é herdado por qualquer NP que tenha tal N como seu núcleo, e atribui Caso Oblíquo para o NP (Larson, 1985: 607):

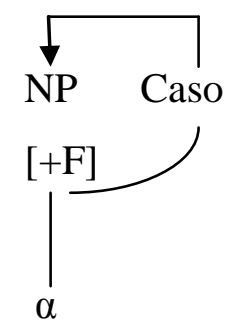


Essa habilidade de marcação de Caso do NP $[+\mathrm{F}]$ permite que esses NPs recebam Caso e satisfaçam o Filtro de Caso na ausência de um atribuidor de Caso externo, como um verbo ou uma preposição. Então, o que distingue NPs que são capazes de funcionar como bare-NP adverbs é um traço intrínseco, com marcação de Caso lexicalmente determinado.

Para o autor, a relativa liberdade de posição sintática observada em relação aos bareNP adverbs pode ser atribuída à Teoria do Caso. Recebendo Caso inerentemente, ou não precisando de Caso, esses elementos não são obrigados a ocorrer adjacentes a algum [-N] ou [+Tense] regente; por isso, dentro do VP, por exemplo, bare-NP adverbs poderão se reordenar livremente com outras categorias de Caso independente, como PP e S' (Larson, 1985: 607):

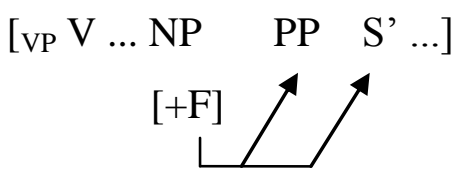

O autor considera ainda os casos que envolvem as seguintes estruturas (Larson, 1985:609):

(76) a. That day passed very quickly.

'Aquele dia passou muito rapidamente'.

b. Few places with a view could be found.

'Poucos lugares com vista poderiam ser encontrados'.

c. We spent that day in New York.

'Passamos aquele dia em Nova Iorque'.

d. We visited few places with a view.

'Visitamos poucos lugares com vista'.

Segundo Larson (1985), os [+F] NPs that day e few places a view ocorrem como sujeitos das sentenças em (76a, b) e como objetos de verbos transitivos em (76c, d). Dada a hipótese de que $[+\mathrm{F}]$ NPs recebem Caso Oblíquo inerentemente, e dado que Nominativo e Caso Objetivo são atribuídos às posições de sujeito e objeto, respectivamente, a expectativa é de que esses exemplos fossem agramaticais em virtude do choque de Caso; entretanto, essas sentenças são bem formadas. Então, o autor propõe que a atribuição de Caso pelo traço $[+\mathrm{F}]$ é 
opcional. Isso implica que embora o traço $[+\mathrm{F}]$ esteja presente nos NPs sujeito e objeto em (76), o Caso Oblíquo não precisa ser atribuído e, por isso, não há choque de Caso.

Resumindo, Larson (1985) conclui que NPs que carregam traço [+F] ocorrem em posição de argumento, por isso, $[+\mathrm{F}]$ não pode ser por si mesmo considerado marcador de Caso: se assim fosse, haveria choque de Caso, uma vez que $[+\mathrm{F}]$ NP ocorre em posição na qual o Caso nominativo é atribuído.

Embora do ponto de vista empírico, o estudo de Larson seja muito interessante, consideramos que a solução do conflito de Caso em termos de opcionalidade na ocorrência do traço $[+\mathrm{F}]$ enfrenta um problema teórico. Como seria possível antecipar a posição em que bare-NP adverbs ocorrem, a fim de definir a presença ou não do traço [+F]? Buscaremos uma solução alternativa para esse problema.

\subsubsection{NPs locativos na posição de sujeito no PB: Pontes $^{43}$ (1986) e (1987)}

As estruturas denominadas Bare-NP adverbs analisadas por Larson (1985) são similares a estruturas produtivas no PB. Em estudo que se tornou seminal para a caracterização do PB, Pontes (1986) demonstra que uma das estratégias utilizadas para o preenchimento do sujeito nessa língua é o alçamento de advérbios locativos e/ou sintagmas de interpretação locativa para a posição de sujeito. A autora analisa, em uma perspectiva funcionalista, estruturas como:

(77) a. As gavetas não cabem mais nada.

b. Essa casa bate bastante sol.

(Pontes: 1986, p.17-18)

A autora observa, inicialmente, que os NPs em (77) possuem um correlato preposicional, como em (78):

(78) a. Nas gavetas não cabe mais nada.

b. Nessa casa bate sol.

\footnotetext{
${ }^{43}$ As obras de Pontes (1986) e (1987) são muito mais amplas do que se apresenta neste trabalho. A autora discute as chamadas construções de tópico-sujeito envolvendo locativos e genitivos. Além de discutir questões pedagógicas: as implicações dessas discussões em sala de aula. Para refletir sobre as questões desta tese, nos restringiremos aos NPs locativos na posição de sujeito, abordados pela autora.
} 
Para Pontes (1987), temos nesse caso o fenômeno da alternância sintática, em que o mesmo sintagma é expresso com ou sem preposição. A autora, de acordo com a perspectiva adotada, postula que tais construções manifestam uma interpretação diferente, propondo que, na versão preposicionada, o grau de impessoalidade é maior, pois, no que se refere às construções não preposicionadas, "o falante nativo sente o primeiro SN como também de algum modo responsável pelo que o verbo veicula. 'Essa casa' é uma casa bem construída, e esta é uma razão pela qual ela recebe tanto sol" (Pontes, 1987: 88). Dessa maneira, para a autora, a responsabilidade pela qualidade está presente na versão sem preposição, mas não está presente na versão preposicionada.

A autora observa em estudo anterior que a concordância verbal e a posição anteposta ao verbo são as características mais marcantes do sujeito em PB, o que daria respaldo para afirmar que os sintagmas destacados em $(79 a, b)$ são sujeitos das sentenças. Para Pontes (1986: 18), o verbo em sentenças como $(79 \mathrm{a}, \mathrm{b})$ concorda com o primeiro SN e não com o segundo, o que impossibilita a anteposição do segundo $\mathrm{SN}$ ao verbo, como indicado pela agramaticalidade de $(79 \mathrm{c}, \mathrm{d})$ :

(79) a. A Belina cabe $60 l$ de gasolina.

b. Esse carro cabe $60 l$ de gasolina.

c. *A Belina cabem $60 l$ de gasolina.

d. *Esse carro $60 l$ de gasolina cabem.

Conforme observa Pontes (1986, p. 19), seria "estranho ao português um sujeito que não pode desencadear a concordância"; então, nesse caso, não poderíamos pensar em um sujeito posposto para estruturas com NPs locativos, como em (79a, b).

\subsubsection{Tópico sujeito e tópico não sujeito no PB: Galves (1998)}

Galves (1998), num quadro da versão minimalista da teoria dos princípios e parâmetros, procura caracterizar as propriedades de estruturas como $(77 \mathrm{a}, \mathrm{b})$ no PB. A autora apresenta evidências de que NPs locativos antepostos ao verbo desempenham a função de sujeito na frase, em oposição aos NPs antepostos a verbos que aparecem em frases marcadamente topicalizadas pela presença de um pronome lembrete. Observemos a estrutura argumental dos dados abaixo: 
(80) a. Bate muito sol *(n)esta casa.

b. Nesta casa, bate muito sol.

c. Esta casa bate muito sol.

d. Esta casa, bate muito sol nela.

(Galves, 1998, p. 21)

Segundo a autora, em (80a) temos a ilustração da projeção imediata da estrutura argumental, na qual a preposição que marca o locativo não pode ser omitida. Os dados em (80b, c, d) ilustram os vários outros recursos de topicalização que a gramática do PB permite. Em (80b) temos a projeção de um PP, mas em (80c, d), temos um NP anteposto ao verbo. A diferença crucial entre elas é que (80d) possui pronome lembrete e (80c) não o possui. Em sua análise, a autora observa que existe uma distribuição complementar entre a presença do pronome lembrete e a concordância entre o NP anteposto e o verbo:

(81) a. Estas casas batem muito sol.

b. *Estas casas batem muito sol nelas.

(Galves, 1998, p.21)

Os dados em (81) demostram que ou o NP anteposto concorda com o verbo, ou é retomado pelo pronome lembrete, o que demonstra dois recursos mutuamente exclusivos na legitimação da anteposição do NP. Há, ainda, outra diferença entre as duas construções, que diz respeito à possibilidade de concordância entre o verbo e o NP posposto:

(82) a. Este carro, cabem muitas pessoas nele.

b. ?? Este carro cabem muitas pessoas.

(Galves, 1998, pp.21-22)

A agramaticalidade de (82b) pode ser atribuída, segundo a autora, ao fato de não haver nenhuma forma de legitimação do NP anteposto: nem concordância, nem retomada pronominal.

Basendo-se no fenômeno da concordância, Galves (1998) defende a hipótese de que os NPs locativos antepostos ao verbo, sem retomada pronominal, são legitimados como sujeito na frase, e se refere a essas construções como de 'tópico-sujeito'. A autora distingue assim construções de tópico-sujeito de construções com retomada pronominal apontando para uma 
propriedade léxico-semântica dos verbos e dos argumentos envolvidos, pois há uma restrição sobre a construção de tópico sujeito que não se verifica na construção com retomada pronominal:

(83) a. Essa estante, o João põe muita coisa nela.

b. ?? Essa estante o João põe muita coisa.

Os dados acima demonstram que não pode haver a projeção do argumento externo do verbo na construção de tópico-sujeito. Segundo a autora, são as seguintes as propriedades que resumem as construções de tópico-sujeito: a) não há pronome lembrete retomando o NP anteposto; b) não há concordância entre o verbo e o NP posposto; c) o argumento externo do verbo está ausente.

\subsubsection{O licenciamento do NP locativo na posição de sujeito}

O estudo de Munhoz (2011) tem por objetivo retomar a questão dos NPs locativos na chamada estrutura de tópico-sujeito. ${ }^{44}$ A autora assume a hipótese de Galves (1998) de que, nas estruturas de tópico-sujeito, o argumento externo do verbo está ausente. A autora atenta para o fato de que a classe dos inacusativos não é homogênea e, apoiando-se nos estudos de Duarte (2003), analisa os verbos inacusativos com os quais a ocorrência do locativo como tópico-sujeito é possível.

Seguindo estudos prévios (cf. Levin \& Rappaport (1995), entre outros), Duarte (2003 apud Munhoz 2011: 91) divide os verbos inacusativos nas seguintes classes semânticas: a) Verbos de mudança de estado: com uma causa externa (alguns dos quais participariam da alternância causativa), como abrir, apodrecer, cristalizar, derreter, fritar e rasgar; com uma causa interna (não alternantes causativamente e não agentivos), de reação física ou psíquica, como empalidecer; de emissão, como explodir, e de mudança de estado devido à causa interna, como crescer, florir e morrer; b) Verbos de movimento: denotam direção inerente, como cair, chegar/ partir, descer/subir, entrar/ sair e ir/vir; c) Verbos de existência e aparição, como os existenciais constar, existir e perdurar, os existenciais locativos, como morar, residir e viver, os que denotam ausência ou carência, como escassear e faltar, os que denotam a entrada em cena de uma entidade, como aparecer, brotar e surgir, os de

\footnotetext{
${ }^{44}$ Destacamos ainda o estudo de Lunguinho (2006), também citado por Munhoz (2011), em que as estruturas de tópico-sujeito genitivo são discutidas.
} 
desaparecimento, como desaparecer e sumir-se, e os eventivos, como acontecer, ocorrer e passar-se.

Segundo Munhoz (2011), verbos de mudança de estado devido a uma causa interna em sentenças de tópico-sujeito locativo têm a particularidade de depender da definitude do DP pós-verbal (p.92):

(84) O campinho de futebol cresceu a grama.

Em relação aos verbos de movimento, Munhoz aponta que alguns pesquisadores sugerem sua biargumentalidade (Holmer, 1999; Cançado; Amaral, 2010; Silva; Farias, 2011 apud Munhoz 2011) e concorda com essa ideia, observando que esses verbos também formam construções de tópico-sujeito locativo (Munhoz, 2011: 93):

(85) a. Arroz mexicano vai banana frita no meio.

b. Cada pacote vem quatro figurinhas.

No entanto, a autora considera que, apesar de os verbos acima serem de deslocamento, o sentido de trajetória parece perdido e essas sentenças focalizam o momento da culminação do evento ou apresentam um sentido existencial:

(86) Em cada pacote, há/ tem/ existem quatro figurinhas.

Munhoz (2011) observa que nem todos os verbos de movimento produzem sentenças gramaticais em estruturas de tópico-sujeito locativo; a princípio, a restrição parece ocorrer com verbos que possuem a informação local-fonte (partir, cair e descer) (p.93):

(87) a. Dois navios partiram daquele porto.

b. *Aquele porto partiu dois navios /*Aquele porto parte cinco navios por dia.

(88) a. Uma fruta caiu no chão.

b. *O chão caiu uma fruta.

(89) a. Um gatinho desceu daquela árvore.

b. ? Aquela árvore desceu um gatinho 
As estruturas com tópico-sujeito locativo também são possíveis com verbos de existência e de aparecimento (Munhoz, 2011: 94):

(90) a. Essa pasta consta todos os documentos necessários.

b. Aquela casa ali mora o Fagner.

c. Seu cabelo tá faltando queratina.

d. O quintal lá de casa apareceu um gatinho.

e. O e-mail da UnB às vezes aparece e desaparece coisas

f. O Japão quase aconteceu um desastre nuclear um dia desses.

Munhoz (2011) acrescenta à lista de Duarte (2003) os verbos caber (corresponde a um predicado estativo e expressa possibilidade de um tema situar-se em um local) e bater (expressa o estado de um elemento tema incidir sobre um local).

Além de demonstrar que verbos inacusativos possuem comportamento heterogêneo, Munhoz (2011) também observa que a literatura tem mencionado a existência de verbos inacusativos biargumentais, os quais possuem dois argumentos, um correspondente àquilo que existe e outro ao local no qual essa entidade existe, observando a possibilidade de os verbos inacusativos, translinguisticamente, poderem se subdividir e poderem tomar um elemento locativo como argumento que pode ocupar a posição de sujeito (Belleti e Rizzi,1998; Levin e Rappaport Hovav, 1995; Tortora, 1997 apud Munhoz, 2011):

Assim, o locativo seria selecionado pelo verbo, uma vez que a ausência do locativo causa agramaticalidade:

(91) a. Essa casa bate bastante sol.

b. *Bate bastante sol.

c. Essa mala cabe muita coisa.

d. * Cabe muita coisa.

(Munhoz \& Naves, 2010: 9)

Nesse sentido, Munhoz (2011), apoiando-se nas constatações de diferentes autores (citados acima) de que os verbos inacusativos têm comportamento heterogêneo e de que alguns inacusativos projetam uma estrutura biargumental, sustenta a hipótese de Munhoz e Naves (2010) de que o tópico-sujeito locativo se licencia com verbos inacusativos biargumentais, assim definidos por selecionarem dois DP's, um tema e um locativo. 
Conforme as autoras demonstram, enquanto o argumento locativo é alçado à posição de sujeito, o argumento Tema permanece em posição interna ao VP.

Munhoz (2011: 120) propõe que estruturas como (92) são resultado de derivações como (93):

(92) Essas malas cabem muita coisa.

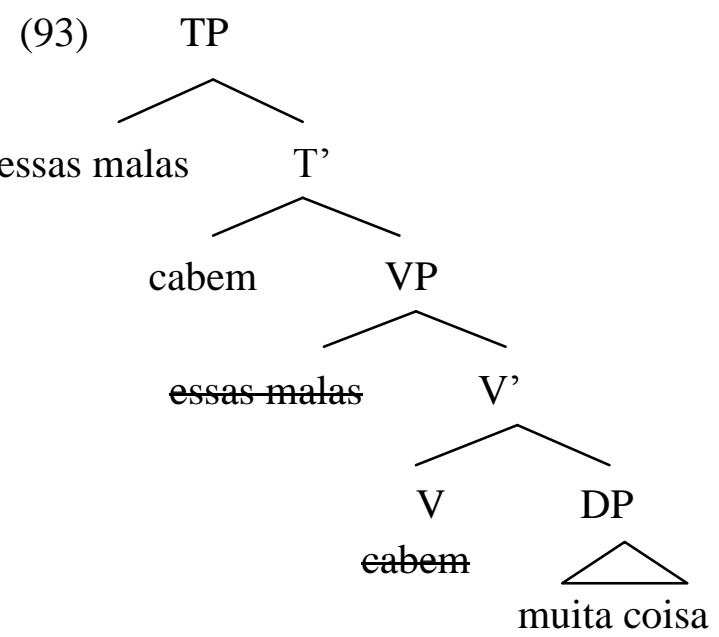

A autora explica que com a ausência de preposição locativa, o sintagma 'essas malas' valora seu Caso estruturalmente, via Agree com T, o que resulta em concordância entre o argumento locativo e o verbo. A hipótese é a de que o verbo se concatene primeiro ao argumento tema, que tem presença obrigatória. $\mathrm{O}$ segundo Merge originará o locativo numa posição de onde ele corresponderá ao Alvo mais próximo identificado pela Sonda e passível de ser alçado à posição de sujeito.

No trabalho de Munhoz e Naves (2010), em que são discutidas as construções de tópico-sujeito genitivo e locativo, as autoras demonstram ainda haver distinção no que se refere à obrigatoriedade desses argumentos, conforme ilustrado em (94a, b) - em que se verifica relação de localização ('sol...(n)a casa') e de possuidor-possuído (pneu...(d)o carro), respectivamente (cf. Munhoz \& Naves 2010)).

(94) a. Essa casa bate sol.

b. Meи carro furou o pneu.

Conforme observado por Munhoz (2011: 62), em ambas as construções o argumento locativo e possuidor preenchem a posição de sujeito, embora tenham estatuto sintático 
distinto: enquanto a supressão de 'do carro', em (95), é possível, a supressão de 'essa casa', em (96), gera agramaticalidade:

(95) a. Furou o pneu.

b. O pneu furou.

(96) a. *Bate bastante sol.

b. *Bastante sol bate.

Observamos que tal contraste se manifesta também em relação à distribuição dos advérbios do tipo 'aqui': enquanto construções do tipo tópico-sujeito locativo autorizam a realização da posição de sujeito por um advérbio do tipo 'aqui', tal categoria não é possível em construções do tipo tópico-sujeito genitivo, como demonstram os dados em (97). Nossa proposta é a de que a restrição não é somente semântica, mas também sintática, uma vez que há relação entre a obrigatoriedade do argumento locativo e a possibilidade de realizar a posição de sujeito por um dêitico locativo (do tipo aqui), modificador do VP - ou inversamente, há relação entre o fato de o genitivo ser gerado na estrutura do DP e a impossibilidade de que seja realizado na posição de sujeito por um constituinte modificador do VP.

(97) a. Aqui bate sol.

b. *Aqui furou o pneu.

Uma questão que permanece em aberto é o fato de que, no nível do VP, o argumento locativo pode ser realizado como DP ou PP. Conforme mencionado anteriormente, o problema da opcionalidade está presente também na análise de Larson (1984), embora neste último estudo, a questão esteja em torno da presença ou não do traço $[+\mathrm{F}]$ em $\mathrm{N}$, que percola para o NP. É o que passamos a discutir.

\subsection{Advérbios locativos na posição de sujeito: a geometria de traços (formais) dos advérbios locativos e sua relação com a categoria nome $(\mathrm{N})$}

Exploramos, até agora, a ocorrência de PPs e NPs locativos na posição argumental. Vimos ainda que os advérbios locativos compartilham a distribuição sintática de tais NPs e PPs, o que sugere que advérbios locativos também podem ocorrer na posição de sujeito: 
(98) a. Aqui /ali/ lá cabe muita gente.

b. Aqui/ ali/ lá bate sol.

c. Aqui/ ali/ lá adoece muita gente.

d. Aqui/ ali/ lá desaparece crianças.

e. Aqui/ ali/lá brota feijão.

f. Aqui/ ali/ lá nasce muita criança.

g. Aqui/ ali/lá morre idoso por falta de atendimento.

h. Aqui/ ali/ lá cresce girassol e margarida.

i. Aquil ali/ lá mora muita gente

j. Aqui/ ali/ lá entrou água

Essas estruturas podem ainda ser discutidas em relação aos usos discursivamente marcados do advérbio 'lá', investigado por Pereira (2011), na hipótese de que são categorias funcionais situadas no nível de CP. O que se verifica é que, nesses usos, o advérbio funcional 'lá' se distingue do advérbio locativo em posição de sujeito, conforme se atesta pela possibilidade de co-ocorrência de ambos (não verificada no caso em que 'lá' ocupa a posição de adjunto, conforme atestado pelo estudo de Pereira (2011):

(99) a. Lá aqui/ ali/ lá entrou água de novo!

b. *Lá eu vou aqui/lá.

c. *Lá vou eu lá.

Em estudo prévio a respeito do estatuto da categoria advérbio, considerado do ponto de vista de sua distribuição sintática na posição de sujeito, Teixeira e Salles (2013a, b) investigam estruturas como (98). A possibilidade de advérbios ocuparem essa posição foi apontada por Bomfim (1988) e associada ao estatuto pronominal dessa categoria, conforme mencionado anteriormente. Na discussão, além das estruturas citadas por Bomfim, incluímos as estruturas propostas por Pontes (1987) e retomadas por Galves (1998), Pilati (2006), Avelar e Cyrino (2008a, b; 2009), Avelar (2009), Munhoz e Naves (2010), Munhoz (2011), e Pilati e Naves (2013), discutidas anteriormente.

A possibilidade de advérbios locativos ocorrerem em tal posição permite identificálos, nesse contexto, com propriedades de $\mathrm{N}$, conforme discutimos em trabalhos anteriores (cf. 
Teixeira e Salles: 2013a, b), em que tomamos como ponto de partida a discussão em Baker (2004) acerca da distinção formal entre categorias lexicais.

Baker (2004) propõe que as categorias lexicais são três: nomes, verbos e adjetivos. O autor questiona o sistema de traços adotado na tradição da teoria gerativa, que distingue as categorias lexicais por traços distintivos binários, levando à identificação de quatro categorias distintas (Chomsky, 1970 apud Baker, 2004: 2):

(100) a. $+\mathrm{N},-\mathrm{V}=$ nome

b. $-\mathrm{N},+\mathrm{V}=$ verbo

c. $+\mathrm{N},+\mathrm{V}=$ adjetivo

d. $-\mathrm{N},-\mathrm{V}=$ preposição, posposição

O autor ressalta, porém, que tal distinção não é suficiente para estabelecer as diferenças entre as categorias lexicais, alegando que tais traços não têm consistência - no sentido de que não determinam classes naturais, uma vez que não só os pares de categorias formados por traços idênticos $\{\mathrm{N}, \mathrm{A}\}$ e $\{\mathrm{V}, \mathrm{P}\}$ compartilham propriedades, mas também os pares de categorias $\{\mathrm{N}, \mathrm{V}\}$ e $\{\mathrm{A}, \mathrm{P}\}$, que são formados por traços opostos. Assim, exemplifica com a identidade do $\operatorname{par}\{\mathrm{A}, \mathrm{P}\}$ com dados do inglês, mostrando que somente AP e PP podem ocorrer com sintagmas de medida, como em It is three yards long e He went three yards into the water do inglês.

Por isso, propõe uma teoria das categorias lexicais em termos dos traços $[+\mathrm{N}]$ e $[+\mathrm{V}]$, mas não como um sistema de oposições binárias, de que resulta o seguinte contraste:

(101) a. Nome é $+\mathrm{N}=$ tem um índice referencial

b. Verbo é $+\mathrm{V}=$ tem um especificador ${ }^{45}$

c. Adjetivo é $-\mathrm{N},-\mathrm{V}$ (é uma categoria default) ${ }^{46}$

\footnotetext{
${ }^{45}$ Conforme Baker (2004: 20), "[t]he basic idea is that only verbs are true predicates, with the power to license a specifier, which they typically theta-mark"/ "a ideia básica é a de que somente verbos são predicados verdadeiros, com o poder de licenciar um especificador, marcados tematicamente."

${ }^{46}$ Conforme Baker $(2004 ; 21)$, “(...) adjective is essentially the "default" category. It appears in a nonnatural class of environments where neither a noun nor a verb would do, including the attributive modification position, the complement of a degree head, resultative secondary predicate position, and adverbial positions."/ "(...) o adjetivo é essencialmente a categoria 'default'. Ele aparece em contextos não-naturais em que nem o nome, nem o verbo apareceriam, incluindo-se a posição de modificação atributiva, o complemento de um núcleo de grau, a posição de predicação secundária resultativa, e posições adverbiais.”
} 
d. Preposição é parte de um sistema diferente (funcional).

(BAKER, 2004, p. 21)

Vamos nos deter em (101a), como propriedade de N para, logo depois, discutirmos a possibilidade de advérbios locativos na posição de sujeito possuírem essa propriedade.

Para Baker (2004), nomes e adjetivos precisam de cópula para serem usados predicativamente e não aceitam tempo morfológico. Além dessas distinções básicas, o autor propõe, entre outras propriedades, a seguinte para $\mathrm{N}$ (p. 95):

(102) Versão sintática: X é um nome se, e somente se, X é uma categoria lexical e $\mathrm{X}$ tem um índice referencial, expresso com um par ordenado.

Assim, nomes são intimamente associados com a função de referência. Também constituem argumentos canônicos da frase, ocupando a posição de sujeito, objeto direto, objeto preposicionado. Nosso objetivo não é aprofundar a argumentação no sentido de detalhar a proposta de Baker, que abrange as diferentes categorias lexicais. Além de muito abrangente, a abordagem desse autor não considera o caso específico dos advérbios. Nesse sentido, buscaremos extrair alguns aspectos que podem ser aplicados à discussão das questões investigadas nesta tese, em relação às propriedades dessa categoria, considerando particularmente os advérbios locativos.

Nossa hipótese é a de que os advérbios locativos compartilham com a categoria $\mathrm{N}$ a propriedade de manifestar índice referencial, exatamente como a categoria $\mathrm{N}$, na proposta de Baker (2004). Nos termos do autor: “(...) the main idea is that only nouns can bear a referential index, because only they have 'criteria of identity' (...) this means that only they can bind anaphors, traces of various kinds, and the theta-roles of verbs, among other things." (p. 21). Embora o autor seja afirmativo no sentido de que as propriedades citadas são exclusivas de N, não é difícil estendê-las aos advérbios (locativos/ de modo), tendo em vista o entendimento de que tais categorias ligam variáveis introduzidas por predicados, como no caso de predicados que selecionam argumentos locativos (Maria pôs o livro na estantelaqui). Além disso, as outras propriedades citadas se confirmam, já que os NPs locativos podem ser antecedentes de palavras QU- em orações relativas, como em (103a, b), antecedente em

47 “A principal ideia é que somente nomes manifestam índice referencial, porque somente eles têm critérios de identidade (...) isso significa que somente eles podem ligar anáforas, vestígios de vários tipos, e papéis temáticos de verbos, entre outras coisas." [tradução minha] 
estrutura coordenada (103c, d) (cf. também dados em (24) e (25), citados em Pilati (2006), e em (51), citados em Avelar (2009)):

(103) a. Brasília ${ }_{i}, q e_{i}$ chove pouco, é a minha cidade predileta.

b. Aqui ${ }_{i}$, que $_{i}$ chove pouco, é a minha cidade predileta.

c. Esse sítio ${ }_{\mathrm{i}}$ dá muitas bananas, mas também $e_{\mathrm{i}}$ é cheio de laranjas.

d. Aqui $i_{\mathrm{i}}$ dá muitas bananas, mas também $e_{\mathrm{i}}$ é cheio de laranjas.

Os fatos relativos à distribuição de advérbios na posição de sujeito - particularmente no PB, diante da exigência de preenchimento dessa posição sintática -, vêm confirmar nossa hipótese no sentido de identificá-los com a categoria $\mathrm{N}$, em relação à manifestação de índice de referencialidade. No entanto, cabe observar que essa propriedade é restrita, a princípio, a um tipo de advérbio - o advérbio locativo.

Tendo em vista a análise de tais construções como inversões locativas, tais estruturas demonstram não só o caráter pronominal dessa categoria, como também destacam a relevância dessa propriedade na gramática do PB. De fato, de acordo com a hipótese das autoras citadas, o PB manifesta o uso dessa construção referida como de tópico-sujeito com caráter inovador, primordialmente, pela presença de concordância verbal nas estruturas com NP locativo (e também pela retomada (opcional) pelo advérbio na posição de sujeito, em caso de realização do argumento locativo posposto ao verbo (cf. (46))).

A ideia de atribuir caráter nominal aos advérbios (locativos) não é recente, conforme discutido em Bomfim (1988), e como vimos, foi retomada por Avelar (2009) na análise das estruturas de tópico-sujeito como casos de inversão locativa. Consideramos que a proposta de assumir uma configuração nucleada por uma categoria do tipo LOC, com o PP (locativo) realizado como complemento, é tecnicamente complexa, sendo possível gerar a estrutura, sem recorrer a essa configuração. Em particular, uma pergunta que se coloca é o que determina a ocorrência dessa configuração, tendo em vista o caráter restrito das construções de tópicosujeito. Além disso, se existe a possibilidade de realizar cada um dos elementos dessa projeção, ou simultaneamente todos, por que algumas línguas implementam o NP (complemento do PP) na posição de sujeito (com implicações para a concordância) e outras não?

Passamos então a explorar a possibilidade de analisar esses casos em termos das propriedades formais do advérbio 'aqui', na relação com PPs e NPs locativos. Como será 
demonstrado, verificamos alguns padrões que nos permitiram postular os traços formais associados a essa categoria em seus usos pronominais.

Assim, partimos dos dados apontados por Pontes (1986), assumindo com essa autora, e com Galves (1998), que, de fato, o NP pleno locativo controla a concordância verbal, conforme ilustrado abaixo, o que constitui um diagnóstico para sua realização na posição de sujeito:

(104) a. Esse sítio dá muitas bananas.

b. Esses sítios dão muita banana.

c. Esse sítio e essa fazenda dão muito banana.

Concordamos também com a hipótese de Pilati (2006) que o PB manifesta a chamada inversão locativa com estruturas $\mathrm{V}(\mathrm{O}) \mathrm{S}$, sendo o locativo realizado lexicalmente ou nulo, este último recuperado anaforicamente ou por uma relação dêictica (locativa ou temporal). Essas estruturas incluem primordialmente orações com verbos inacusativos e verbos transitivos em narrativas concomitantes, e também estruturas transitivas ergativizadas, conforme observam Galves (1998) e Avelar; Cyrino (2009a, b), em que o argumento externo não recebe marcação morfossintática. Seguimos também a análise de Munhoz e Naves (2010) e Munhoz (2011) de que o NP locativo realizado na posição de sujeito é argumento (interno) do verbo em estruturas com verbos inacusativos biargumentais. Incluímos, ainda, estruturas com verbos meteorológicos, discutidas em Pilati e Naves (2013), em que o uso de locativos parece manifestar as propriedades postuladas para os casos anteriores - destacando-se a possibilidade de controlar a concordância:

(105) a. Brasília/ Aqui chove muito.

b. Essas cidades chovem muito.

No entanto, ao examinarmos advérbios locativos em estrutura de coordenação, verificamos que a situação de concordância de número não se mantém, o que sugere que os advérbios locativos não manifestam o traço de número, embora manifestem, por hipótese, o 
traço de pessoa interpretável, por manifestarem índice de referencialidade ${ }^{48}$. Esse contraste está ilustrado a seguir:

(106) a. Aqui e ali bate sol à tarde.

c. *Aqui e ali batem sol à tarde.

(107) a. Aqui e ali cabe muita coisa.

b. *Aqui e ali cabem muita coisa. ${ }^{49}$

Vimos que a ausência de traço de número no advérbio locativo é também referida em Avelar (2009), como uma propriedade que interage com o caráter defectivo da concordância do $\mathrm{PB}$, diante do fenômeno da variação na flexão verbal, dando origem à inversão locativa no PB. Conforme mencionado anteriormente, nosso entendimento é o de que a concordância variável observada no PB não deve ser tomada como um fator determinante em relação à possibilidade de licenciar, na posição de sujeito, uma categoria como o locativo, tida como defectiva pela ausência do traço de número. Antes, consideramos relevante a proposta de Pilati (2006) de vincular a inversão locativa no PB à codificação da dêixis na estrutura oracional.

Nesse sentido, propomos que a inserção de PP/Advérbio locativo (lexical ou nulo) e de DP locativo em SpecTP satisfaz a codificação da dêixis (temporal e locativa), exigida nesses contextos - nesse aspecto, ampliamos a proposta em relação a Pilati (2006), que não inclui PP locativo nessa posição. A categoria T, por sua vez, manifesta traços phi (de pessoa e número), não interpretáveis, e o traço EPP, os quais são verificados pela categoria realizada em SpecTP, conforme indicado a seguir.

$\mathrm{Na}$ presença de advérbios locativos, que, por hipótese, não manifestam traço de número, concluímos que o traço de $\left(3^{\mathrm{a}}\right)$ pessoa, considerado interpretável por manifestar índice referencial, é suficiente para desencadear $A G R E E$, sendo o traço de número validado como singular, que é a opção default no sistema flexional do verbo no PB.

\footnotetext{
${ }^{48}$ Em Pilati, Naves e Salles (2013, em preparação), é desenvolvida a hipótese de que o advérbio locativo (lexical ou nulo) na posição de sujeito as estruturas de inversão locativa no PB é uma categoria que satisfaz o traço EPP em T, bem como a variável locativa da estrutura lexical do predicado, no caso das construções de tópico-sujeito (cf. Munhoz \& Naves 2010; Munhoz 2011) e a exigência do traço dêictico nas configurações VS e nas estruturas com sujeito genérico (cf. Pilati 2006).

${ }^{49}$ Agradeço ao professor Marcel den Dikken (The City University of New York) por discutir tais dados comigo em ocasião do VIII Congresso Internacional da Abralin 2013.
} 
Considerando as especificidades da distribuição de DP locativos e PP/Advérbios locativos em SpecTP nas estruturas de inversão locativa, no que se refere à concordância (plena ou default, respectivamente), propomos tentativamente que DP locativos têm traços de pessoa e número, validando completamente os traços-phi, e manifestando Caso nominativo, enquanto PP/Advérbios locativos manifestam o Caso oblíquo (inerente) - o que sugere uma situação de Quirky Case ${ }^{50}$. Em particular, consideramos que o Caso oblíquo (inerente), no caso do advérbio, é determinado no nível lexical/ categorial, ou no nível da sintaxe, na presença da preposição.

Por hipótese, o Caso oblíquo, nessa configuração, não entra em conflito com a operação AGREE no nível de TP, uma vez que, no caso do advérbio, somente o traço de pessoa em T é verificado, sendo o traço de número validado como singular, que é a opção default; na presença de PPs, têm-se, por hipótese, somente o traço EPP licenciado, já que os traços de número e pessoa não são acessíveis, sendo, portanto, validados na opção default $-3^{\text {a }}$ pessoa e singular.

Seguindo estudos prévios, assumimos que o locativo satisfaz a exigência do traço [+Loc] seja da estrutura oracional (no caso de VS e de construções com sujeito genérico, conforme Pilati 2006), seja do predicado (no caso das construções de tópico-sujeito, conforme Munhoz \& Naves 2010; Munhoz 2011). Por essa razão, apesar da concordância variável no $\mathrm{PB}$, nem todos os elementos sem traço de número podem ocupar tal posição. Assim, propomos que os elementos locativos que ocupam a posição em SpecTP, conforme ilustram (108) e (109), possuem os seguintes traços formais:

1. DP locativo: [+Loc], [+Pessoa], [+Caso], [+Número];

2. Advérbio locativo: [+Loc], [+Pessoa], [+Caso];

3. PP locativo: [+Loc], [+Caso].

Como a língua apresenta, no sistema flexional do verbo, número e pessoa default, o advérbio locativo e o PP locativo ocupam, assim como o DP locativo, a posição em Spec TP, porque satisfazem a exigência do traço [+Loc] do predicado (no caso das construções de tópico-sujeito), ou da estrutura da oração (no caso das construções VS ou de sujeito genérico).

\footnotetext{
${ }^{50}$ Segundo Boeckx (2000), há elementos que são marcados na superfície com Quirky Case na posição de sujeito, apesar de não terem Caso Nominativo, que é o Caso associado, canonicamente, a essa posição. Logo, sugerimos a situação de Quirky Case no PB no sentido de que os locativos se comportam como sujeitos sem desencadear Agree (no caso de PP locativos), ou por manifestar Agree incompleto (no caso de Adv locativos).
} 

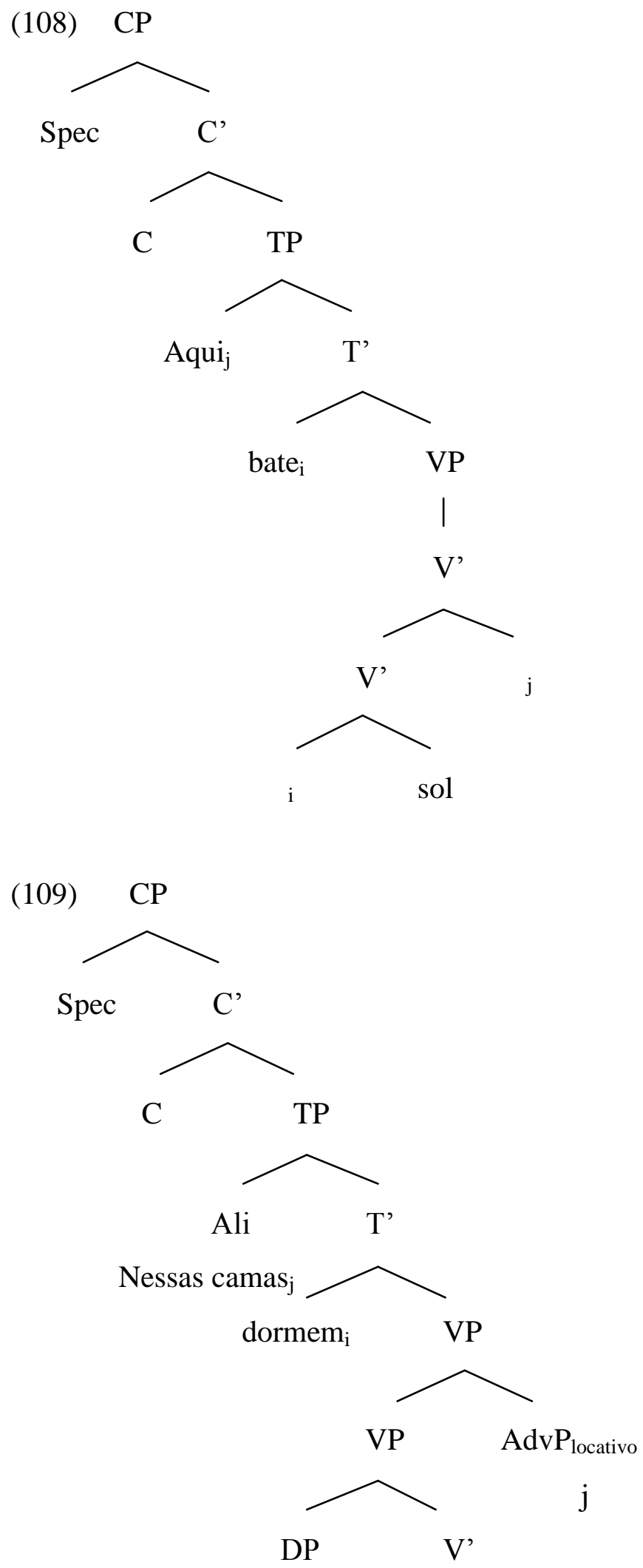

As crianças

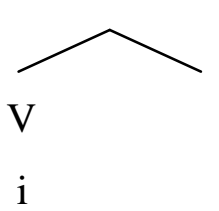


Retomando a proposta de Larson (1985), vimos a possibilidade de as línguas manifestarem os chamados Bare NPs Adverbs. O autor propõe que essas expressões seriam marcadas no léxico por um traço $[+\mathrm{F}]$, responsável por codificar 'tempo, lugar, modo', o que as tornaria inerentemente marcadas para o Caso oblíquo (havendo, porém, a possibilidade de não manifestarem o traço $[+\mathrm{F}]$ caso ocorram na posição de sujeito, evitando-se o conflito de Caso). Considerando a dificuldade técnica de assumir uma regra de opcionalidade nesse tipo de modelo teórico, e ainda o fato de que as expressões que satisfazem essa 'regra' são de diferentes tipos, postulamos que tais elementos compartilham a propriedade de manifestar índice de referencialidade, o qual é codificado pelo traço de [pessoa], na computação sintática. Essa propriedade se manifesta por meio dos seguintes recursos, nos seguintes níveis da gramática:

1. Em advérbios locativos ou circunstanciais de tempo marcados para o traço [+dêitico] (como aqui e agora), no nível da oposição categorial, em que se distinguem as classes de palavras;

2. Em nomes que denotam dias da semana (domingo, $4^{a}$ feira), no nível do léxico; as línguas podem ser menos restritivas e incluir nome marcado por quantificação existencial, como no caso do inglês, que inclui 'someplace' (You have lived someplace; Peter put the letter someplace), o que confirma o caráter lexical da regra, ainda que envolva processo sintático para marcar a quantificação.

3. Em nomes que denotam tempo, em estruturas que incluem categorias marcadas para o traço [+dêitico] (pronomes demonstrativos), constituindo-se, portanto, no nível da sintaxe, como em that day/ aquele dia, em inglês e português (Aquele/*O dia choveu muito) - embora seja ainda acionada uma marcação no léxico, já que existe seleção de palavras que denotam tempo.

4. Em (bare) NPs ou DP quaisquer, desde que selecionados por predicados, como em Essa casa bate sol - nesse caso, o traço [+dêitico] é atribuído ao DP pelo predicado.

Observamos ainda que advérbios locativos coordenados não desencadeiam concordância em construções como as apresentadas em (106) e (107), mas desencadeiam-na em construções como as que ilustram os dados abaixo:

(110) a. Aqui e ali são meu refúgio. 
b. *Aqui e ali é meu refúgio.

A pergunta que se coloca é por que os advérbios locativos coordenados desencadeiam concordância nas estruturas de cópula, mas não nas estruturas de inversão locativa examinadas anteriormente (cf. (106), (107)). Nossa hipótese inicial é a de que, nesse contexto, a possibilidade de concordância no plural está associada ao fato de que o predicado é do tipo 'equativo', que denota a identidade entre os traços referenciais do NP 'meu refúgio' e do sintagma locativo realizado pelo advérbio. Nesse tipo de configuração, o advérbio locativo não satisfaz propriedades argumentais associadas ao verbo, que é um auxiliar. O núcleo do predicado é o NP 'meu refúgio'. Nessa configuração, o NP predica de forma distributiva de cada advérbio, o que explicaria a possibilidade de realizar o verbo no plural ${ }^{51}$.

\subsection{Considerações parciais}

Neste capítulo, discutimos a terceira questão que levantamos neste trabalho. Para discuti-la, contrastamos dados em que advérbios, PPs e NPs locativos ocupam a posição de sujeito. Iniciamos com a apresentação dos estudos de Bresnan (1994), que traz a proposta de que, na inversão locativa no chicheŵa e no inglês, o locativo é o sujeito gramatical. Apresentamos também a análise de Pilati (2006) para as estruturas (VS) no PB, que incluem as estruturas de tópico-sujeito, as quais são analisadas como estruturas de inversão locativa, em que locativos ocorrem na primeira posição. Passamos então a discutir as análises de Galves (1998), Avelar e Cyrino (2008) e (2009), Avelar (2009) para discutir o estatuto do PP locativo na posição de sujeito no PB. Os autores defendem que o PP locativo pode ocupar a posição de sujeito devido ao fato de, no PB, os traços- $\phi$ de T serem defectivos em relação aos traços de número. Observamos que o trabalho dos autores não explica o fato de haver concordância plena quando o locativo perde a preposição e se realiza como NP locativo anteposto ao verbo.

Seguimos com a apresentação do trabalho de Larson (1985), que propõe para estruturas com bare-NP adverbs um traço $[+\mathrm{F}]$ atribuidor de Caso oblíquo opcional. O fato de esse traço ser opcional, segundo o autor, permite que bare-NP adverbs ocupem posição argumental, recebendo Caso nominativo (sem que haja conflito com o Caso oblíquo). Consideramos que a solução do autor para o conflito de Caso em termos de opcionalidade na

\footnotetext{
${ }^{51}$ Neste trabalho, apenas apontamos esse tipo de estrutura com cópula, que poderá ser objeto de pesquisa futura, já que necessita de uma análise mais refinada.
} 
ocorrência do traço $[+\mathrm{F}]$ enfrenta um problema teórico. Como seria possível antecipar a posição em que Bare-NP adverbs ocorrem, a fim de definir a presença ou não do traço $[+\mathrm{F}]$ ? Considerando tal dificuldade técnica, propusemos que tais elementos compartilham a propriedade de manifestar índice de referencialidade, o qual é codificado pelo traço de [pessoa], na computação sintática.

Para a análise de dados com NPs locativos na posição de sujeito, recorremos aos estudos de Pontes (1986) e (1987), Galves (1998), Munhoz e Naves (2010) e Munhoz (2011), que demonstram que NPs locativos são capazes de desencadear concordância no plural. Refinando o trabalho de Munhoz e Naves (2010), Munhoz (2011) propõe que essas estruturas são licenciadas com verbos inacusativos biargumentais: verbos com dois complementos, um tema e um locativo. A questão que levantamos, e ainda continua em aberto, diz respeito ao fato de, no nível do VP, o argumento locativo poder ser realizado como DP ou PP. O problema da opcionalidade também está presente na análise de Larson (1984), embora neste caso, a questão esteja em torno da presença ou não do traço $[+\mathrm{F}]$ nos denominados bare-NP adverbs.

Partimos da hipótese de Baker (2004) de que a categoria N manifesta índice referencial e chegamos à conclusão de que advérbios locativos compartilham com a categoria $\mathrm{N}$ tal propriedade e, por isso, podem ser coindexados, conforme observam Pilati (2006) e Avelar (2009), a uma categoria vazia que desempenha papel de sujeito numa oração coordenada e controlam o sujeito da oração encaixada.

Para finalizar, retomamos nossos estudos anteriores, observando que NP's locativos comportam-se de maneira distinta de advérbios locativos. NP's locativos são capazes de desencadear concordância, advérbios locativos em estrutura de coordenação não a desencadeiam. Supomos que tais NPs manifestam traço de número inerente, enquanto advérbios locativos não possuem tal traço, como podemos rever nos seguintes dados:

(111) a. Esse sítio dá muitas bananas.

b. Esses sítios dão muita banana.

c. *Aqui e ali dão muita banana.

Observamos que a ausência do traço de número no advérbio locativo também é postulada por Avelar (2009), como uma propriedade que interage com o caráter defectivo de T no PB. Consideramos que a concordância variável observada no PB não parece ser um fator determinante em relação à possibilidade de licenciar uma categoria como o locativo. 
Consideramos atraente a proposta de Pilati (2006) de vincular a inversão locativa no PB à codificação da dêixis na estrutura oracional.

Nesse sentido, concluímos com a proposta de que a inserção de PP/Advérbio locativo (lexical ou nulo) e de DP locativo em SpecTP satisfaz as exigências no que se refere à codificação da dêixis (em consonância com os estudos prévios citados). No caso de advérbios locativos, que, por hipótese, não manifestam traço de número, mas manifestam o traço de $3^{\mathrm{a}}$ pessoa (referencial), concluímos que o traço de número em T é validado como singular, que é a opção default (na gramática do $\mathrm{PB}$ ), sendo o traço de pessoa suficiente para desencadear AGREE. Ainda, no que se refere à concordância (plena ou default), considerando as especificidades da distribuição DP locativos e PP/Advérbios locativos em SpecTP nas estruturas de inversão locativa, propomos tentativamente que: 1) DP locativos são marcados com o Caso nominativo, uma vez que possuem os seguintes traços: [+Loc], [+Pessoa], [+Número] e [+Caso], e verificam os traços de T (completos); 2) PP/Advérbios locativos são marcados com o Caso oblíquo (inerente) - o qual, por hipótese, não entra em conflito com a operação AGREE no nível de TP, pelo caráter defectivo dessa operação: na presença de advérbios, AGREE valida o traço de pessoa em T (mas não o de número, que é validado como singular, que é a opção default no sistema flexional do verbo); na presença de PP locativo, não há marcação de Caso, e os traços de pessoa e número de T são validados na opção default (não havendo, como no finlandês, concordância de número com um DP associado). Concluímos, então, que advérbios e PP locativos podem ocupar a posição em Spec TP, assim como os DP locativos, uma vez que satisfazem a exigência do traço [+Loc] no predicado. 


\section{CONSIDERAÇÕES FINAIS}

Esta tese teve como objeto de investigação as propriedades sintáticas e semânticas dos advérbios. Conforme amplamente demonstrado na literatura, os itens lexicais que compõem esta categoria manifestam propriedades distintas, e por vezes ambíguas, já que alguns advérbios compartilham da distribuição sintática de PPs, NPs e Adjetivos. Adotando-se a abordagem da gramática gerativa, essas características suscitam questionamentos sobre os traços formais envolvidos e como os traços compartilhados ou não podem contribuir para a definição do estatuto categorial do advérbio e de suas subclasses. Levantamos, então, três questões relativas à categorização do advérbio, apresentadas em nossa introdução e repetidas a seguir:

Questão 1: Quais propriedades os advérbios compartilham com outras classes? Quais propriedades os distinguem? Possuindo propriedades distintas e compartilhadas, é possível supor que pertencem à mesma categoria 'advérbio'? Pertencendo à mesma categoria, é possível postular subclasses? Pertencendo a categorias distintas, que categorias são essas?

Questão 2: Tendo em vista a maior ou menor mobilidade dos advérbios na estrutura oracional, que propriedades licenciam sua distribuição sintática? Existe correlação entre a mobilidade dos elementos adverbiais e sua distribuição em subclasses? De que maneira as propriedades de cada subclasse interage com a distribuição sintática desses elementos?

Questão 3: Os advérbios, em contextos específicos, ocupam a posição de sujeito no PB ou estão na periferia da oração, por deslocamento à esquerda? Em cada caso, quais são os fatores sintáticos e semânticos responsáveis pelo licenciamento de advérbios? Que fatores restringem a presença de outros advérbios nessa posição?

Para abordar essas questões, no capítulo 1, apresentamos brevemente aspectos históricos da tradição gramatical para a categorização das palavras. Esta retomada nos permitiu observar, particularmente, o legado helenístico da gramática tradicional no que se refere à caracterização dos advérbios, pois a essência de sua caracterização se mantém desde os filósofos gregos: palavra invariável, que ocorre como modificadora de verbos, adjetivos e do próprio advérbio. No entanto, testando alguns dados, percebe-se rapidamente o comportamento complexo do advérbio, pois pode modificar categorias diversas. Nesse 
sentido, demonstramos que a discussão sobre as categorias remonta aos estudos gregos, embora mantenha-se até hoje, na linguística moderna, a preocupação em discutir os problemas colocados pelos dados que envolvem a ocorrência dessa categoria. Para finalizar o capítulo, apresentamos em linhas gerais os pressupostos teóricos da Teoria Gerativa, em que se verifica a importância teórica da noção de categoria, e a partir dos quais discutimos as questões levantadas neste trabalho.

Para abordar a questão 1, no capítulo 2, desenvolvemos uma discussão sobre propriedades compartilhadas e distintivas entre advérbios e outras categorias. Os estudos de Lemle (1984), Bomfim (1988) e Lobato (1989) analisam as propriedades compartilhadas por advérbios e preposições. Lemle (1984) postula que advérbios pertencem à categoria das preposições baseando-se na distribuição sintática entre advérbios e PPs e no processo diacrônico de aglutinação entre advérbios e preposições, que manteria o rótulo inicial PP. No entanto, vimos que Bomfim (1988) contesta a hipótese de Lemle (1984), demonstrando que há contextos em que PPs e advérbios não são intercambiáveis e que advérbios possuem propriedades, como poderem ser intensificados, que as preposições não têm. Lobato (1989) dialoga com as propostas de Lemle (1984) e Bomfim (1988) concordando que elementos como dentro, fora são advérbios e não preposições. Vimos, ainda, nos estudos de Bomfim (1988), que certos advérbios locativos e temporais comportam-se de maneira distinta dos demais advérbios, compartilhando propriedades com os pronomes e podendo ocupar a posição de sujeito em estruturas de cópula, como em 'Aqui é um bom lugar para dormir'.

Abordamos, em seguida, ainda no Capítulo 2, a discussão sobre a hipótese de flutuação categorial entre advérbios e adjetivos, em contextos do tipo 'Maria anda torto'/ 'Maria anda tortamente'. Apresentamos a análise de Lobato (2005/2008), que propõe que, nesses contextos, não existe flutuação, mas sim um adjetivo em função de adjetivo (torto) e um advérbio em função de advérbio (tortamente), uma vez que, em 'Maria anda torto', a predicação recai sobre uma propriedade nominal (implícita) na estrutura léxico-conceptual do verbo, mantendo-se a autonomia categorial em relação ao advérbio. Leung (2007) e Foltran (2010) discutem a hipótese de Lobato (2005/2008) no que se refere à hipótese de predicação de uma propriedade nominal do verbo. Enquanto Leung (2007) refina a proposta de Lobato postulando que tais estruturas são licenciadas com verbos que denotam atividade, que possuem uma semântica de produção, licenciando um objeto cognato eventivo, Foltran (2010) postula que adjetivos e advérbios (em -mente) compõem uma única categoria, definida pelos traços $[+\mathrm{N}+\mathrm{V}]$, distinguindo-se, essencialmente, em relação ao tipo de modificação que realizam (de entidade ou evento), sendo as formas em -mente um tipo de adjetivo flexionado. 
A discussão sobre o estatuto categorial neste capítulo demonstrou que a ambiguidade dos itens lexicais que compõem a categoria advérbio é apenas aparente, uma vez que é possível demonstrar a autonomia do advérbio, em relação às preposições, aos pronomes e aos adjetivos (ainda que a análise de Foltran proponha a unificação em uma única categoria de adjetivos e advérbios em - mente modificadores de predicado). De fato, enquanto a análise de Lobato (2005/2008) e de Leung (2007) propõem a distinção categorial de adjetivos e de advérbios, Foltran (2010) mantém a autonomia categorial por outro viés: a proposta de uma categoria $[+\mathrm{N}+\mathrm{V}]$, na qual os advérbios predicativos são, por hipótese, adjetivos flexionados. A discussão apresentada nesse capítulo reforçou nossos questionamentos sobre a existência de subclasses dentro da categoria advérbio, por um lado, e para a caracterização do advérbio em oposição a outras categorias, por outro.

Para discutir a questão 2, examinamos, no capítulo 3, a sintaxe dos advérbios, e verificamos que alguns possuem mais mobilidade na estrutura oracional do que outros, além de ocorrerem em posições relativas específicas. Em relação à mobilidade, vimos que os advérbios mais altos possuem mais mobilidade; enquanto advérbios mais baixos (os de VP) possuem menor mobilidade (Jackendoff, 1972; Cinque, 1999), com restrições em determinadas posições. Em relação à posição relativa de diferentes advérbios, verificamos que existem duas propostas principais: a de Cinque (1999), que postula que os advérbios são licenciados como especificadores de núcleo funcionais em posições fixas acima de VP, distinguindo-se dos adjuntos circunstanciais, que são licenciados no nível do VP e podem ser realizados como NPs ou como PPs (ex.: aqui, este lugar, neste lugar), e a de Ernst (2004), que distingue advérbios predicacionais, que ocorrem como adjuntos acima de VP, e se distribuem por relações de escopo, e os adjuntos que não envolvem relações de escopo (como os locativos, instrumentais e benefactivos) e os que envolvem relações fracas de escopo (como os funcionais de negação, tempo e frequência).

Questionando a proposta de Cinque (1999) e apoiando-se na proposta de Ernst (1984), Costa (2008) demonstra que as propriedades semânticas e lexicais dos advérbios têm implicações para a sua distribuição sintática, consequentemente, a mobilidade desses advérbios na estrutura da oração está ligada ao sentido inerente que possuem, o que leva ao questionamento da proposta cartográfica de Cinque (1999).

Por fim, apresentamos a análise de Pereira (2011), que investiga propriedades do advérbio 'lá' em usos discursivamente marcados. Adotando a análise de Cinque (1999), a autora propõe que o advérbio 'lá', nesses contextos, está situado na posição de especificador de núcleos funcionais situados na periferia da oração, o que vem confirmar, por um lado, a 
mobilidade do advérbio do tipo circunstancial locativo e, por outro, a pertinência da proposta cartográfica de Cinque (1999).

Diante da complexidade das questões envolvidas, deixamos a avaliação mais detalhada do modelo de Cinque (1999) e de Ernst (2004) para investigação futura. As propostas discutidas nesse capítulo reforçaram, porém, a nossa hipótese sobre a existência de subclasses de advérbios, sendo relevante, para a presente investigação, a distinção entre advérbios sentenciais (altos) e os advérbios de VP (baixo). Dos advérbios de VP extraímos a subclasse dos locativos ${ }^{52}$, os quais se distinguem dos demais por poderem realizar-se como PPs ou como NPs, podendo, por hipótese, ocupar a posição de sujeito (supostamente por sua maior mobilidade na oração).

No capítulo 4, nos detivemos na análise de advérbios de VP, particularmente, dos advérbios locativos e seus correspondentes NPs e PPs locativos que podem ocupar a posição de sujeito. Este capítulo propiciou-nos uma reflexão mais voltada para a questão 3; no entanto, consequentemente, também nos remete às questões 1 e 2. Apontamos, baseando-nos nos estudos de Pontes (1986), (1987) e de Galves (1998), que há uma mudança gramatical no PB no que diz respeito ao paradigma da flexão verbal. Com os morfemas de flexão verbal reduzidos, o PB tem demonstrado a tendência de preencher a posição de sujeito e, para preenchê-la, postula-se que uma das estratégias é o alçamento de PPs, NPs e advérbios locativos para essa posição.

Para abordar a questão, apoiamo-nos na hipótese de Pilati (2006) de que as estruturas VS do PB são casos de inversão locativa, que manifestam um locativo (lexical ou nulo), na posição de sujeito. Para discutir essa hipótese, apresentamos o estudo de Bresnan (1994), que investiga as propriedades da inversão locativa, e a ocorrência de PPs locativos na posição de sujeito no inglês e no chicheŵa. Baseando-se em alguns critérios, entre eles, a concordância entre o sujeito e o verbo, a autora postula que, nas estruturas conhecidas como inversão locativa, o locativo é o sujeito gramatical, já que no chicheŵa os verbos possuem um prefixosujeito que concorda com o sujeito gramatical e, no chicheŵa, esse prefixo-sujeito é obrigatório nos locativos quando há inversão. Na análise de dados do inglês, a autora ressalta que não há concordância do verbo com o locativo, mas com o tema. No entanto, apesar da

\footnotetext{
${ }^{52}$ Deste grupo, excluímos a realização do advérbio locativo como categoria codificadora de propriedades evidenciais (ex.: Quero lá ver isso!), estes, por hipótese, podem compor outra subclasse, mas não aprofundamos essa questão.
} 
falta de concordância (com o elemento na posição de sujeito), o inglês apresenta uma classe de verbos de alçamento que permitem a inversão locativa, demonstrando as mesmas propriedades do chicheŵa, além da evidência de que nenhum constituinte não-sujeito pode ser alçado em inglês. Nesse sentido, embora haja diferenças no desencadeamento da concordância, a autora propõe que o locativo é o sujeito gramatical tanto no chicheŵa, quanto no inglês. A proposta da autora nos levou a refletir sobre o desencadeamento de concordância como critério para ocupar a posição de sujeito, pois, como vimos no decorrer do capítulo, em estruturas como 'Aquil Essa gaveta cabe muita coisa' / 'Essa gaveta e esse baú/*Aqui e ali cabem muita coisa', temos a concordância com o DP locativo, mas não com o advérbio locativo (em estrutura de coordenação).

Para refletir sobre estruturas com inversão locativa no $\mathrm{PB}$, recorremos ao estudo de Pilati (2006), que analisa propriedades sintáticas e semânticas de estruturas com ordem VS no PB. A autora demonstra que há uma exigência de dêiticos (locativos e temporais), ou de dêiticos nulos recuperados anaforicamente nessas estruturas. Assim, a presença da interpretação dêitica em estruturas com ordem VS do PB leva a autora a propor que essas estruturas manifestam propriedades de inversões locativas.

Continuamos a discussão com os estudos de Avelar e Cyrino (2008) e (2009), e Avelar (2009) para os PPs locativos na posição de sujeito no PB. Os autores propõem que, na ausência do argumento externo, o PP locativo pode checar o EPP de T. Essa possibilidade é justificada pelo fato de que, no $\mathrm{PB}$, a concordância verbo-sujeito não é obrigatória (é variável), podendo a categoria $\mathrm{T}$ ser licenciada na ausência de traços-phi. A hipótese de que a concordância variável no PB indica que o núcleo T pode ser licenciado independentemente de traços -phi não nos pareceu adequada como fator responsável por determinar a ocorrência do PP locativo na posição de sujeito, pois, nesse caso, outros PPs, além dos locativos, poderiam ocupar essa posição, o que não parece possível. As análises dos autores discutem as estruturas em que o PP locativo aparece na posição de sujeito, mas não discutem os dados em que DPs locativos desencadeiam concordância 'Essas casas batem sol'.

Sobre a questão da alternância entre PPs e DPs locativos, passamos a expor o estudo de Larson (1985), que faz uma análise dos denominados bare-NP adverbs: sintagmas nominais que podem funcionar como modificadores adverbiais, sem o acompanhamento de preposições ou de qualquer outro indicador do status de adjunção. $\mathrm{O}$ autor propõe que esses itens possuem um traço $[+\mathrm{F}]$ que lhes atribui Caso oblíquo inerente, no entanto, a hipótese é a de que se trata de um Caso opcional, uma vez que bare-NP adverbs podem ocorrer em posição de sujeito ou de objeto e receber Caso nominativo ou objetivo, respectivamente. A 
proposta do autor é muito interessante, mas consideramos que a solução do conflito de Caso em termos de opcionalidade na ocorrência do traço $[+\mathrm{F}]$ enfrenta um problema teórico, pois, nesse contexto, seria necessário antecipar a posição em que bare-NP adverbs ocorrem, a fim de definir a presença ou não do traço $[+\mathrm{F}]$.

Partindo dos bare-NP adverbs estudados por Larson (1985), investigamos a ocorrência de PP/Advérbios e DP locativos nas construções de tópico-sujeito, no PB, estendendo as conclusões aos demais contextos em que esse é postulada a presença do locativo. Recorremos aos estudos de Pontes (1986) e (1987), Galves (1996), Munhoz e Naves (2010) e Munhoz (2011) para aprofundarmos a discussão sobre o NP e o PP/advérbio locativo na posição de sujeito. Os estudos das autoras demonstram que NPs locativos na posição de sujeito possuem as principais características do sujeito canônico no PB: estar anteposto ao verbo e desencadear concordância: 'Essas gavetas cabem muita coisa'. Os estudos de Munhoz e Naves (2010) e Munhoz (2011) aprofundam a análise desses dados, demonstrando que, nessas estruturas, o locativo se licencia na posição de sujeito com verbos inacusativos biargumentais, sendo assim, o locativo é selecionado pelo verbo e, na ausência de um argumento externo, é alçado à posição de sujeito.

Retomando a análise de Cinque (1999) de que advérbios circunstanciais possuem a característica de realizarem-se como PPs ou como NPs locativos, manifestando maior mobilidade, passamos então a investigar as características do advérbio locativo na posição de sujeito. Partindo da hipótese de que, se NPs, PPs e advérbios locativos compartilham distribuição sintática, poderão também compartilhar propriedades categoriais, buscamos refinar a hipótese de estudos anteriores de nossa autoria (Teixeira e Salles, 2013a, b), em que postulamos que advérbios locativos (como aqui, aí, la ${ }^{53}$ ) compartilham com os nomes (N) a propriedade, postulada em Baker (2004), de manifestar índice referencial, o que se confirma pela possibilidade de esses elementos, assim como os NPs locativos, serem antecedentes de palavras -QU, como por exemplo, em orações relativas: 'Aqui IEssa gaveta $_{i}$, que ${ }_{i}$ cabe muito coisa, é a minha predileta'.

Observamos então que advérbios podem ocupar a posição de sujeito assim como os NPs locativos: 'Essa casa bate sol' / 'Aqui bate sol'. No entanto, notamos que, com o advérbio locativo, assim como com o PP locativo, a concordância não é desencadeada: 'Essas casas batem sol' / ‘*Aqui e ali batem sol'. Como o NP e o advérbio ocupam a mesma posição sem mudança de sentido, propomos que NPs locativos possuem traço de número e pessoa, o

\footnotetext{
${ }^{53}$ Excluindo os usos discursivamente marcados (cf. Pereira, 2011).
} 
que licencia o desencadeamento de concordância no plural. Já no caso dos advérbios locativos, a nossa hipótese é de que têm o traço de $3^{\mathrm{a}}$ pessoa e não apresentam traço de número. Mas, ainda assim, a Sonda T identifica o traço (interpretável) de pessoa no sintagma locativo, e ocorre a operação Agree, que permite a checagem do traço (não-interpretável) de $3^{\mathrm{a}}$ pessoa em $\mathrm{T}$. Na ausência do traço de número no advérbio locativo, o traço (nãointerpretável) de número em T é validado como singular, que é a opção default. A propriedade [+dêitico] juntamente com o traço de $3^{\mathrm{a}}$ pessoa permitem que esses advérbios ocupem a posição de sujeito no PB.

Postulamos, então, que na presença de DP locativo, que possui os traços [+Pessoa], [+Número], [+Loc] e [+Caso], os traços-phi em T são completamente valorados, e o DP locativo checa Caso Nominativo; e na presença do advérbio que possui, por hipótese, os traços [+Loc], [+Pessoa] e [+Caso (oblíquo)], é valorado o traço de pessoa em T, e o traço de número é realizado como singular, que é a opção default no sistema de flexão do verbo; na presença de PP locativo que, por hipótese, possui os traços [+Loc] e [+Caso (oblíquo)], os traços de número e pessoa de T são validados na opção default. Tais elementos podem ocupar a posição SpecTP por serem capazes de satisfazer a exigência do traço [+Loc] no predicado.

Com este estudo, esperamos ter contribuído para a compreensão do estatuto do advérbio, e de suas subclasses, considerando, em particular, um grupo específico: os advérbios locativos. No entanto, sabemos que questões aqui apontadas geram outras questões, que podem ser molas propulsoras para pesquisas futuras. Em particular, consideramos relevante investigar o estatuto da preposição na estrutura do PP locativo, que alterna com o DP locativo. A possibilidade de alternância entre o PP e o DP locativo, sugere que a categoria $\mathrm{P}$ manifesta propriedades de um núcleo funcional. 


\section{REFERÊNCIAS BIBLIOGRÁFICAS}

AVELAR, J. Inversão locativa e sintaxe de concordância no português brasileiro. In Matraga. Rio de Janeiro. Vol.16, n.24, jan./jun. 2009.

AVELAR, J. \& CYRINO, S. Sintagmas locativos e concordância no português brasileiro. XV Congresso da ALFAL, 18-22, ago.2008a.

. Locativos preposicionados em posição de sujeito: uma possível contribuição das línguas Bantu à sintaxe do português brasileiro. In Revista de Estudos Linguísticos da Universidade do Porto. Vol.3. 2008b. pp. 55-75.

Sobre constituintes locativos pré-verbais: paralelismos entre o português brasileiro e as línguas Bantu (versão preliminar). In: MORAIS, Maria Aparecida Torres; ANDRADE, Maria Lúcia C. V. de O. História do português paulista. Campinas: Publie/ Fapesp, 2009. pp. 218-249.

BAKER, M.C. Lexical Categories: verbs, nouns and adjectives. Cambridge University Press, 2004.

BOECKX, Cedric. Quirky Agreement. In Studia Linguistica 54(3) 2000, pp.354-380.

BOMFIM, Eneida. Advérbios. São Paulo: Ática, 1988.

BRESNAN, J. (1994). Locative Inversion and the Architecture of Universal Grammar. In Language, Vol.70, № 1 , pp.72-131.

\& KANERVA. 1989. Locative inversion in Chichewa: A case study of factorization of grammar. Linguistic Inquiry 20(1), 1-50.

CÂMARA JR., J Mattoso. História e estrutura da língua portuguesa. $2^{\mathrm{a}}$ ed., Rio de Janeiro: Padrão, 1979.

Estrutura da Língua Portuguesa. Petrópolis: Vozes, 2004.

CHOMSKY, N. Lectures on government and bilding. Dordrecht: Foris, 1981.

Knowledge of Language: Its Nature, origin and use. New York: Praeger Publisher, 1986 (Versão portuguesa, tradução de Anabela Gonçalves e Ana Teresa Alves; O Conhecimento da Língua: sua natureza, origem e uso. Lisboa: Caminho, 1994). 
.The Minimalist Program. Massachusets: MIT Press, 1995. [O Programa Minimalista. Tradução, Apresentação e Notas à tradução de RAPOSO, Eduardo. Lisboa: Editorial Caminho, 1999].

. Novos Horizontes no Estudo da Linguagem e da Mente. São Paulo: Unesp, 2005.

Sobre natureza e linguagem. Organizado por Adriana Belletti e Luigi Rizzi; tradução Marylene Pinto Michael; revisão da tradução Evandro Ferreira e Silva. São Paulo: Martins Fontes, 2006.

On phases. In: R. Freidin; C. P. Otero; M.-L. Zubizarreta (eds.) Foundational Issues in Linguistic Theory: Essays in Honor of Jean-Roger Vergnaud, 2008.

CINQUE, G.(1999). Adverbs and functional heads: A cross-linguistic perspective. New York: Oxford University Press. . (2004) Issues in Adverbial Syntax. Lingua 114.683-710.

COSTA, J. (2004). A multifactorial approach to adverb placement: assumptions, facts, and problems. Lingua 114. p. 711-753.

COSTA, J. (2008). Adverbs and the syntax-semantics interplay. Estudos Linguísticos/Linguistic Studies 2. Edições Colibri, p. 13-25.

CUNHA, C. \& CINTRA, L.F.L. Nova Gramática do Português Contemporâneo. Rio de Janeiro: Nova Fronteira, 2001.

DUARTE, Maria Eugênia. Do pronome nulo ao pronome pleno: a trajetória do sujeito no português do Brasil. Roberts \& M.A.Kato (orgs) Português Brasileiro uma viagem diacrônica. Campinas: Editora da UNICAMP, 1993. p. 107-128.

A perda do princípio "evite pronome" no Português Brasileiro. Tese de Doutorado. UNICAMP (1995).

ERNST, Thomas (1984). Towards an Integrated Theory of Adverb Positions in English. Ph.D. Dissertation. Indiana University Linguistics Club. Bloomington: Indiana. (2002). The syntax of adjuncts. Cambridge University Press. 
(2010). Adverbs and Light Verbs. Proceedings of the 22nd North American Conference on Chinese Linguistics (NACCL-22) \& the 18th International Conference on Chinese Linguistics (IACL-18). 2010. Vol 2. Clemens, L.E. \& C.-M. L. Liu, eds. Harvard University, Cambridge, MA. 178-195.

FIGUEIREDO SILVA, Maria Cristina. A posição do sujeito no português brasileiro: frases finitas e infinitivas. Campinas: Editora da Unicamp, 1996.

FOLTRAN, M.J.G.D. A alternância entre adjetivos e advérbios como modificadores de indivíduos e de eventos. In Revista Letras (n.81). Curitiba: Editora UFPR, 2010. p.157-176.

GALVES, Charlotte (1996). O enfraquecimento da concordância no PB. In I. Roberts, Kato (orgs). Português Brasileiro: uma viagem diacrônica. Campinas, SP: Ed. da Unicamp, 387408.

(1998). Tópicos e Sujeitos, Pronomes e Concordância no Português Brasileiro. In Cadernos de Estudos Linguísticos (nº 34) Campinas, SP: UNICAMP/IEL. p.19-31.

GONZAGA, M. Aspectos da Sintaxe do Advérbio em Português. Dissertação de Mestrado. Lisboa: Faculdade de Letras da Universidade de Lisboa, 1997.

HORNSTEIN, N., J. NUNES e K.K. GROHMANN. Understanding Minimalism. New York: Cambridge University Press, 2005.

ILARI, R. et al (1989). Considerações sobre a Posição dos Advérbios, in A. T. Castilho, (org.), Gramática do Português Falado -Vol. I: A ordem. Campinas, SP: Editora da UNICAMP, 2002, p. 53-120.

JACKENDOFF, R. (1972). Semantic Interpretation in Generative Grammar. Cambridge: MIT Press.

LEVIN, B. \& RAPPAPORT, H. 1995. Unaccusativity at the Syntax-Lexical Semantics Interface. Cambridge, Mass., MIT Press.

KATO, Mary. 2000. A Restrição de Mono-Argumentalidade da Ordem VS no Português do Brasil. Fórum Lingüístico, 2: 97-127.

KENEDY, E. Curso básico de linguística gerativa. São Paulo: Contexto, 2013. 
KRATZER, A. Building Resultatives. In: MAIENBORN, C.; WÖLLENSTEIN-LEISTEN, A. (Eds.). Event arguments in syntax, semantics, and discourse. Tübingen: Niemeyer, 2005.

LARSON, R.K. Bare-NP Adverbs. In: Linguistic Inquiry, Vol. 16, Number 4. Cambrige: MIT, 1985.

Events and modification in nominals. In: STROLOVITCH, D.; LAWSON, A.(Eds.) Proceedings from Semantics and Linguistic Theory (SALT) VIII. Ithaca: Cornell University, 1998.

LEMLE, M. Análise Sintática: teoria geral e descrição do português. São Paulo: Ática, 1984.

LEUNG, R.T.F. Um estudo sobre os objetos cognatos e os adjetivos adverbiais no português do Brasil. Dissertação de Mestrado. São Paulo: Universidade de São Paulo, 2007.

LEVIN, B.\& HAPPAPORT, H.M. Unaccusativity: at the syntax-lexical semantics interface. Cambridge, MA: MIT Press, 1995.

LOBATO, L.M.P. Sintaxe gerativa do Português: da teoria padrão à teoria da regência e ligação. Belo Horizonte: Vigília, 1986.

Advérbios e preposições, sintagmas adverbiais e sintagmas preposicionais. In Delta, v. $5, \mathrm{n}^{\circ} 1, \mathrm{p} .101-120,1989$.

De novo sobre advérbios e preposições, sintagmas adverbiais e sintagmas preposicionais in HEYE, Jügen (org). Flores verbais: uma homenagem linguística e literária para Eneida do Rego Monteiro Bomfim no seu 70ªniversário. Rio de Janeiro: Ed. 34, 1995. pp 23-39.

Sobre o suposto uso adverbial de adjetivo: a questão categorial e as questões da variação e da mudança linguística. In: CONGRESSO INTERNACIONAL DA ABRALIN, 2005, Brasília.

. Sobre o suposto uso adverbial de adjetivo: a questão categorial e as questões da variação e da mudança lingüística, in VOTRE, S. e RONCARATI, C. (orgs). Anthony Julius Naro e a Linguística no Brasil: uma homenagem acadêmica. Rio de Janeiro: 7 Letras, 2008. 
LUNGUINHO, M. V. da S. (2006) Partição de constituintes no português brasileiro: características sintáticas. In. SILVA, D. E. da (ed.) Lìngua, Graumática e Discurso. Goiânia: Cânone; Grupo de Estudos Linguísticos do Centro-Oeste, p. 133-147.

MACAMBIRA, J.R. A Estrutura Morfossintática do Português: aplicação do estruturalismo lingüístico. São Paulo: Pioneira Thomson Learning, 2001.

MIYAGAWA, S. Why agree? Why move? Unifying agreement-based and discourse configurational languages. Linguistic Inquiry Monograph 54, MIT Press, 2010.

MUNHOZ, A.T.M. (2011) A estrutura argumental das construções de tópico-sujeito: o caso dos sujeitos locativos. Dissertação (Mestrado) - Universidade de Brasília.

MUNHOZ, A.T.M. \& NAVES, R.R. (2010). Notas a respeito da estrutura argumental de verbos com alternância entre tema e locativo no português brasileiro. In Anais do IX Encontro do Centro de Estudos Linguísticos do Sul (CELSUL). Universidade do Sul de Santa Catarina.

NASCIMENTO, M. 1984. Sur la Postposition du Sujet dans le Portugais du Brésil. Tese de doutorado, Universidade de Paris VIII.

NEVES, M.H. de Moura. A vertente grega da gramática tradicional: uma visão do pensamento grego sobre a linguagem. 2.ed. rev. e atual. - São Paulo: Editora UNESP, 2005.

PEREIRA, Bruna (2011). A sintaxe cartográfica de 'lá' no português brasileiro: um estudo da periferia esquerda. Tese de Doutorado. Universidade Federal de Minas Gerais.

PERINI, M. A. Gramática Descritiva do Português. São Paulo: Ática, 2006.

PEZATTI, E. 1993. A ordem das palavras e o caráter nominativo/ergativo do português falado. ALFA, 37: 159-178.

PILATI, E. (2002). Sobre a ordem verbo sujeito no português do Brasil. Dissertação de mestrado, Universidade de Brasília.

- (2006) Aspectos Sintáticos e Semânticos de Orações com Ordem Verbo Sujeito no português do Brasil. Tese de Doutorado. Universidade de Brasília. 
PILATI, E.; R. R. NAVES. Desenvolvendo a hipótese da cisão de traços pronominais no português brasileiro in MOURA, D. e SIBALDO, M.A. (organizadores.) Estudos e Pesquisas em teoria da gramática EDUFAL: Maceió, 2013.

PILATI, E.; NAVES, R. R.; SALLES, H.M.M.L de. (2013) Locative/ possessor raising, deictic (locativel temporal) pronouns in subject position in BP. Encontro do GT-TG da ANPOLL, São Paulo, 2013.

PINKER, Steven. O Instinto da Linguagem. São Paulo: Martins Fontes, 2002.

PINTO, Manuela. 1997. Licencing and Interpretation of Inverted Subjects in Italian. Tese de Doutorado. LED, Utrecht.

PONTES, E. S. L.(1986). Sujeito: da sintaxe ao discurso. São Paulo: Ática; (Brasília): INL, Fundação Nacional Pró-Memória.

. (1987). O tópico no português do Brasil. Campinas: Pontes.

RAPOSO, E.P. Teoria da Gramática: a faculdade da linguagem. Lisboa: Caminho, 1992.

RUWET, N. Introdução à gramática gerativa. Tradução e adaptação Carlos Vogt. São Paulo: Perspectiva, 2009.

TEIXEIRA, Z.D. (2008). Tipologias semânticas de advérbios: um estudo comparativo. Dissertação (mestrado). Pontifícia Universidade Católica do Rio de Janeiro.

Advérbios: uma análise semântica e suas implicações para o ensino de língua portuguesa. Curitiba: Editora CRV, 2010.

Propriedades sintáticas e semânticas dos advérbios em português. In Anais do VII Congresso Internacional da Abralin. Curitiba: 2011.

TEIXEIRA, Z.D. \& SALLES, H.M.M.L. de A. Distribuição sintático-semântica dos advérbios em português. In Denilda Moura e Marcelo Amorim Sibaldo (orgs.). Estudos e pesquisas em teoria da gramática. Maceió: EDUFAL, $2013 a$.

TEIXEIRA, Z.D. \& SALLES, H.M.M.L. de A. Advérbios locativos na posição de sujeito no PB. Trabalho apresentado no VIII Congresso Internacional da Abralin. Natal: 2013b (a publicar). 